\title{
29. PLIOCENE-PLEISTOCENE ARAGONITE CYCLIC VARIATIONS IN HOLES 714A AND 716B (THE MALDIVES) COMPARED WITH HOLE 633A (THE BAHAMAS): RECORDS OF CLIMATE-INDUCED $\mathrm{CaCO}_{3}$ PRESERVATION AT INTERMEDIATE WATER DEPTHS ${ }^{1}$
}

\author{
André W. Droxler, ${ }^{2}$ Geoffrey A. Haddad, ${ }^{2}$ David A. Mucciarone, ${ }^{2}$ and James L. Cullen ${ }^{3}$
}

\begin{abstract}
Ocean Drilling Program (ODP) Leg 115 post-cruise research was focused on two Maldives sites, more precisely on the top $108 \mathrm{~m}$ of Hole 716B (water depth, $540 \mathrm{~m}$ ), equivalent to the past $3.5 \mathrm{~m} . \mathrm{y}$. , and the top $19.5 \mathrm{~m}$ of Hole $714 \mathrm{~A}$ (water depth, $2195 \mathrm{~m}$ ), equivalent to the past $0.55 \mathrm{~m} . \mathrm{y}$. These sediments consist of mostly unaltered and undisturbed, turbidite-free, periplatform ooze. Results of our research are compared with existing data on Hole 633A (water depth, $1681 \mathrm{~m}$ ), drilled in the Bahamas during ODP Leg 101, using age/depth models built on the basis of oxygen isotope, nannofossil, and magnetic stratigraphies.

Climate-induced, long-term (roughly 0.5 m.y.) aragonite cycles, superposed on short-term (roughly 0.04 and 0.1 m.y.) aragonite cycles, have been established at least during the past 2.0 m.y., in the Maldives and the Bahamas. Our most interesting result is the clear correlation among the aragonite long-term cycles in the Maldives and the Bahamas and the carbonate-preservation, long-term cycles from the open Pacific, Indian, and North Atlantic oceans. The midBrunhes dissolution interval, corresponding to the youngest preservation minima of the carbonate-preservation, longterm cycles, is clearly defined by fine aragonite minimum values in the deep periplatform sites, and by maximum fragmentation of pteropod tests in the shallow sites. Aragonite and planktonic $\delta^{18} \mathrm{O}$ records, usually in phase during the late Pleistocene, display, further back in time, discreet intervals where the two records do not match with one another. Major mismatches between both records occur synchronously in the Maldives and Bahamas periplatform sites and seem to correspond to extreme events of either carbonate-preservation or dissolution in the deep pelagic carbonate sites of the equatorial Pacific Ocean.

Based on our findings, short- and long-term aragonite cycles can no longer be explained only by variations of aragonite input from the nearby shallow carbonate banks, in response to their alternate flooding and exposure through cyclic sea-level fluctuations. The aragonite long-term cycles in the periplatform environments are interpreted as carbonatepreservation cycles at intermediate-water depths. Their occurrence shows, therefore, that the carbonate chemistry of the entire water column has been influenced by long-term $(0.5 \mathrm{~m} . \mathrm{y}$.) cyclic variations during the past $2.0 \mathrm{~m} . \mathrm{y}$. These major changes of the water-column carbonate chemistry are linked to the climate-induced carbon cycling among the different atmospheric, oceanic, and sedimentary carbon reservoirs.
\end{abstract}

\section{INTRODUCTION}

Deep-sea carbonate sediments play an important role in the global carbon cycle by storing or releasing large volumes of carbon through time. Because of the chemical interactions at the seafloor between sediments and the overlying water masses, deep-sea carbonate sediments have also recorded, at least partially, the carbonate chemistry variations of different water masses. In addition, since the general deep-ocean circulation is modulated and intimately linked to global fluctuations of Quaternary climate, deep-sea sediments contain unique records of the interactions between the atmosphere and the ocean.

Below the calcite lysocline $(3500-4000 \mathrm{~m})$, deep-sea sediments have recorded cyclic changes of the ocean carbonate chemistry over the Milankovitch orbital time scale $\left(10^{4}-10^{5} \mathrm{yr}\right)$ in deep- and bottom-water masses. Above the calcite lysocline, in intermediate-water depths, little or no dissolution is generally observed in planktonic calcitic sediments, which consist mainly of coccolith and foraminifer tests. Aragonite, a less stable carbonate phase and therefore more sensitive to minor chemical

\footnotetext{
1 Duncan, R. A., Backman, J., Peterson, L. C., et al., 1990. Proc. ODP, Sci. Results, 115: College Station, TX (Ocean Drilling Program).

2 Department of Geology and Geophysics, Rice University, P.O. Box 1892, Houston, TX 77251, U.S.A.

3 Department of Geological Sciences, Salem State College, Salem, MA 01970, U.S.A.
}

changes than calcite, has been used to study the carbonate chemistry variations at intermediate-water depths. Previous studies have used the occurrence and depth distribution of pteropods (planktonic micro-mollusks with aragonitic tests) to define the aragonite lysocline and aragonite compensation depth (ACD) at intermediate-water depths (Chen, 1964; Herman, 1971; Berner, 1977, 1981; Berger, 1978; Berner et al., 1976; Droxler et al., 1988a). Chen (1968) and Herman (1971) are among a few authors who have related the downcore pteropod distribution to late Pleistocene paleoclimatic fluctuations. To our knowledge, however, no studies based on the downcore occurrence and distribution of pteropod tests have demonstrated cyclic changes of the ocean carbonate chemistry within Milankovitch frequencies $\left(10^{\text {th }}-100^{\text {th }} \mathrm{k} . \mathrm{y}\right.$. $)$ in oceanic intermediate-water masses. These cycles would be analogous to the cyclic carbonate variations well established in the three major oceans that have mainly recorded carbonate chemistry variations of deep- and bottom-water masses.

The late Pleistocene aragonite cycles observed in the periplatform ooze, deposited in the deep surroundings of the carbonate Bahamas Banks, are well established and have been the subject of several studies (Supko, 1963; Kier and Pilkey, 1971; Lynts et al., 1973; Droxler et al., 1983; Boardman et al., 1986; Haddad, 1986; Burns and Neumann, 1987; Slowey et al., 1989). The detailed correlation between the aragonite cycles and the oxygen isotope planktonic record (Droxler et al., 1983; Boardman et al., 1986) shows the clear tie between the aragonite cycles and the late Pleistocene climatic fluctuations. The origin of 
these cycles, however, has remained quite controversial for the past $5 \mathrm{yr}$ (for a summary, see Droxler and Schlager, 1985b; Droxler, 1986; Boardman and Neumann, 1985, 1986).

One way to explain the periplatform aragonite cycles is by simply varying the input of bank-derived aragonite. Variations in input are directly tied to alternate flooding and exposure of the shallow carbonate banks and, therefore, are a direct result of late Pleistocene climate-induced, sea-level fluctuations (Supko, 1963; Kier and Pilkey, 1971; Boardman et al., 1986; Boardman and Neumann, 1985, 1986). Export of bank-derived fine aragonite toward the deep basins is directly modulated by maximum aragonite production during intervals of bank flooding and by minimum aragonite production during intervals of bank exposure. Supko (1963), Kier and Pilkey (1973), Lynts et al. (1973), Boardman (1978), Schlager and Chermark (1979), Hanna and Moore (1979), Mullins et al. (1980), Hine et al. (1981), Mullins (1983), Droxler et al. (1983), Boardman and Neumann (1984), Droxler and Schlager (1985a), and Reymer et al. (1988) have described and summarized this concept as "carbonate high-stand shedding." In this case, therefore, high aragonite content in periplatform sediments corresponds to interglacial stages (sealevel high stand), whereas low aragonite content corresponds to glacial intervals (sea-level low stand).

Carbonate cycles are well established in deep waters of the equatorial Pacific (Arrhenius, 1952; Hays et al., 1969; Berger, 1973; Thompson and Saito, 1974; Pisias et al., 1975; Adelseck, 1977; Volat et al., 1980; Farrell and Prell, 1987, 1989), Indian (Oba, 1969; Volat et al., 1980; Peterson and Prell, 1985; Williams et al., 1985), and Atlantic oceans (Berger, 1973; Gardner, 1975; Volat et al., 1980; Balsam, 1983; Diester-Haas, 1985; Crowley, 1983, 1985). By analogy with these carbonate cycles, a second way to explain the aragonite periplatform cycles is to modify the aragonite input (concept of carbonate high-stand shedding) by varying its degree of preservation through partial or full seafloor dissolution. Carbonate preservation at the seafloor is tied to climate-induced changes in carbonate chemistry of intermediate-water masses, specifically to the shallowing or deepening of the aragonite saturation level. In the latter case, the aragonite cycles become analogous to the carbonate (calcite) cycles well established in the deep oceans and mainly explained by climate-induced fluctuations in planktonic calcite production and preservation on the seafloor. Modification of the aragonite input signal by seafloor dissolution is not always obvious, especially in the late Pleistocene aragonite cycles in the Bahamas, where input and preservation signals appear to be in phase, as usually is the case for carbonate cycles in the deep North Atlantic Ocean (Volat et al., 1980; Crowley, 1983). Interglacial stages, which are characterized by maximum aragonite input, would then correspond to intervals of good carbonate preservation, whereas glacial stages, characterized by low aragonite input, would correspond to intervals of poor preservation

Given the subtle evidence and careful observations, we have favored the interpretation initiated by Lynts et al. (1973) that the aragonite cycles are formed by varying the input of bank-derived aragonite, which is subsequently either fully preserved or partially/totally dissolved by chemical reaction with the overlying water masses at the seafloor (Droxler et al., 1983, 1988b; Droxler, 1985). The major evidence consists of the following:

1. The general asymmetry of the aragonite cycles (sharp glacial-to-interglacial transitions followed by gentle interglacial-toglacial transitions) cannot be clearly explained by flooding and exposure of the carbonate banks, because of the characteristic flat bank tops and steep bank edges. This typical bank physiography should lead to sudden flooding during an interval of sealevel rise as well as to sudden exposure once sea level falls. The aragonite input function should, therefore, be symmetrical.
2. The close tie between aragonite and oxygen isotope signals is remarkable and occurs not only during interglacial stages, but also during glacial stages when aragonite production, and therefore input, could not have varied much because the shallow banks were exposed. Detailed analyses of the last glacial-to-interglacial transitions also clearly show that the last bank flooding in the Bahamas occurred several thousands of years after the recorded aragonite increase in the basins (Droxler et al., 1983; Droxler, 1985). Direct observations of aragonite dissolution in waters of less than $800 \mathrm{~m}$ based on pteropod tests are quite rare. Pteropod fragmentation seems to increase during the past several glacial intervals in a core collected from Northwest Providence Channel in the Bahamas at only $680 \mathrm{~m}$ (Haddad, 1986); and pteropod casts, resulting from sea floor dissolution, were observed during the last glacial intervals in cores from Northwest Providence Channel (Burns, 1983).

The cyclic pattern of carbonate preservation in deep waters is not always in phase with interglacial intervals, as is typically the case for the North Atlantic Ocean during the late Pleistocene (Berger, 1973; Gardner, 1975; Volat et al., 1980; Balsam, 1983; Diester-Haas, 1985; Crowley, 1983, 1985). In contrast, the carbonate preservation pattern in the Pacific Ocean is totally out of phase with the Atlantic pattern. In the Pacific Ocean, better preservation roughly corresponds with glacial intervals and dissolution roughly with interglacial intervals (Arrhenius, 1952; Hays et al., 1969; Berger, 1973; Thompson and Saito, 1974; Pisias et al., 1975; Adelseck, 1977; Volat et al., 1980; Farrell and Prell, 1989). In addition to these differences between basins, a global pattern of carbonate preservation common to the three major oceans appears during the late Pleistocene and is characterized by generally good preservation at the glacial-to-interglacial transitions and generally poor preservation at the interglacial-to-glacial transitions (Crowley, 1985).

To investigate the origin of the aragonite cycles further, we expanded our research geographically by establishing research programs in periplatform environments on the Nicaragua Rise (Caribbean Sea), the Maldives (Indian Ocean), and the Queensland Plateau (southwest Pacific Ocean) (Droxler et al., 1989). The Atlantic and Pacific patterns, characteristic of the carbonate (calcite) cycles, seem also to appear at intermediate-water depths in the periplatform aragonite cycles. On the Queensland Plateau (southwest Pacific Ocean), aragonite values are higher during the second half of the last glacial stage and lower during the past $6000 \mathrm{yr}$ and during the previous interglacial stage. In the Maldives, aragonite maxima always occur at the glacial-tointerglacial transitions, whereas aragonite minima occur at the interglacial-to-glacial transitions. A similar pattern in deep-water carbonate records (i.e., good carbonate preservation at the glacial-to-interglacial transition and poor preservation at the interglacial-to-glacial transition) has been demonstrated by Peterson and Prell (1985) from the Ninetyeast Ridge (eastern equatorial Indian Ocean) and by Farrell and Prell (1989) from the equatorial Pacific Ocean.

We also expanded our research further back in time than the late Pleistocene by studying longer periplatform sequences collected in the Bahamas and in the Maldives during Ocean Drilling Program (ODP) Legs 101 and 115. In Hole 633A (the Bahamas), Droxler et al. (1988b) have demonstrated that the aragonite cycles did not always remain in phase with the oxygen isotope record. In several cases, the aragonite increase clearly lags or leads the oxygen isotope depletion characteristic of an interglacial/glacial transition. Because a constant-phase relationship is required by the high-stand hypothesis, we think that the aragonite cycles cannot be solely explained by high-stand shedding. In addition, aragonite supercycles in Hole 633A were revealed by connecting the minimum aragonite values for the 
successive Pleistocene glacial stages. The timing of these aragonite supercycles, characterized by a periodicity of roughly 0.4 $0.5 \mathrm{~m} . \mathrm{y}$., is in good agreement with the timing of the long-term carbonate preservation records well established in the Pacific, Indian, and Atlantic oceans (Hays et al., 1969; Adelseck, 1977; Vincent, 1985; Moore et al., 1982; Farrell and Prell, 1987, 1989; Oba, 1969; Peterson and Prell, 1985; Crowley, 1985; DiesterHaas, 1985).

Two long periplatform sequences were drilled during Leg 115 at Site 716 (540 m water depth, 108-m-thick unaltered periplatform sequence corresponding to the past $3.5 \mathrm{~m} . \mathrm{y}$.) and at Site 714 (2195 m water depth, 19.5-m-thick unaltered periplatform sequence corresponding to the past 0.55 m.y.) (Backman, Duncan, et al., 1988). This is a unique opportunity to extend the existing late Pleistocene aragonite record in the Indian Ocean (Droxler et al., 1989) back to the Pliocene, and to compare two aragonite records from different water depths (540 and $2195 \mathrm{~m}$ ) for the past $0.55 \mathrm{~m} . \mathrm{y}$. Based on these new records, we can address several new questions.

1. How have the climate-induced aragonite cycles evolved during the early and middle Pleistocene as well as during the late Pliocene? Specifically, how have major climatic events such as the onset of major glaciations in the Northern Hemisphere at 2.4 Ma (Shackleton et al., 1984), or the change from high frequencies/low amplitudes to low frequencies/high amplitudes at the early/middle Pleistocene boundary (0.9 Ma; Prell, 1982) been recorded in the aragonite record?

2. How well does the aragonite record correlate with the oxygen isotope record on planktonic foraminifers? What is the phasing between the aragonite and oxygen records? Can we observe any systematic pattern with the phase changes or the different time lags between the two signals?

3. Do the aragonite supercycles discovered in the Bahamas (Droxler et al., 1988b) also occur in the Maldives? If yes, do these aragonite supercycles in the Maldives correlate with the ones in the Bahamas as well as with the carbonate supercycles well established in the equatorial Pacific and Atlantic oceans.

Because a 2.1-m.y. continuous aragonite record has already been determined in Hole 633A from the Bahamas (Droxler et al., 1988b), a comparative study between the two late Pliocene/ Pleistocene aragonite records from the Maldives and from the Bahamas can easily be done. To help the comparison between the two records, we present our data vs. time instead of core depth, given age/depth models built on oxygen isotope, nannofossil, and magnetic stratigraphies.

\section{LOCATION AND SEDIMENT DESCRIPTION}

The Maldives Archipelago consists of a double chain of atolls separated by a series of deep internal basins with water depths ranging from 200 to $600 \mathrm{~m}$. The archipelago is located on top of an elevated ridge, $2500 \mathrm{~m}$ above the adjacent abyssal plains (Fig. 1). Because of this particular physiographic setting, the sediments deposited in close proximity to the shallow carbonate environments cover a wide range of water depths (200$2500 \mathrm{~m}$ ). This paper presents the results of a post-cruise research program that focused on two long periplatform records from Holes $714 \mathrm{~A}$ and $716 \mathrm{~B}$, collected by advanced piston coring (APC) in the central part of the Maldives Archipelago during Leg 115.

In Hole $716 \mathrm{~B}$, we recovered a single 260 -m-thick lithologic unit consisting mainly of foraminifer-bearing nannofossil calcareous ooze without any distinct turbidite layers (Backman, Duncan, et al., 1988). The sedimentary sequence at Site 716 represents a somewhat continuous late Miocene through Pleistocene record. Although the first appearance of chalky levels was shallow (75 mbsf), a complete transformation from ooze to chalk was not evident even at the bottom of Hole 716B. The chalk proportions ranged from $10 \%$ to $60 \%$ and were highly variable from one core to another in the bottom half of Site 716. We have restricted our detailed studies to the top $108 \mathrm{~m}$ (Cores $115-716 \mathrm{~B}-1 \mathrm{H}$ to $-12 \mathrm{H}$ ) of Hole $716 \mathrm{~B}$ to avoid sediment with obvious signs of diagenetic recrystallization. The top eight cores are chalk free, whereas Cores $115-716 \mathrm{~B}-9 \mathrm{H}$ to $-12 \mathrm{H}$ contain a maximum of $5 \%$ chalk.

We also analyzed 10-20-cm-spaced samples from the 19.5m-thick upper unit of Hole 714A corresponding to late/middle Pleistocene age $(0.55 \mathrm{Ma})$. This upper unit overlies the very top of Unit II, a greenish gray nannofossil ooze of late Miocene age (8.0 Ma, NN10 [CN8]; Backman, Duncan, et al., 1988). A 7.5m.y. hiatus, therefore, separates the bottom of Unit I and the top of Unit II and its presence unfortunately has limited our study of Hole $714 \mathrm{~A}$ to the late/middle Pleistocene. Lithotypes of this upper unit range from foraminifer-bearing, clay-bearing nannofossil ooze to foraminifer-bearing clayey nannofossil ooze. These sediments, which display cyclic color changes, do not include any chalk. A single turbidite $50 \mathrm{~cm}$ above the hiatus at the Unit I/II boundary, was identified in Holes 714A and 714B, suggesting only minor disturbance in Unit I (Backman, Duncan, et al., 1988).

Onshore laboratory analyses, including size fraction separation, carbonate content, carbonate mineralogy, and stable oxygen isotope on planktonic foraminifers, show that these sediments consist of a mixture of pelagic, calcitic ooze and of bankderived fine aragonite and magnesian calcite, typical for a periplatform ooze (Schlager and James, 1978).

For comparison with the new data generated from Holes $714 \mathrm{~A}$ and $716 \mathrm{~B}$, we have included in this paper results from the top $43.75 \mathrm{~m}$ of Hole $633 \mathrm{~A}$, which were published in the Proceedings of the Ocean Drilling Program, Scientific Results, Volume 101 (Droxler et al., 1988b). Hole 633A was drilled in the southern part of Exuma Sound on the toe-of-slope of the Great Bahama Bank, in $1681 \mathrm{~m}$ water depth (Fig. 1). The top $43.75 \mathrm{~m}$ corresponds to Unit I, defined in Austin, Schlager, et al. (1986) as a periplatform-ooze sequence with cyclic variations in color and a few scattered 1-10-cm-thick calcareous turbidite layers. Considering the proximal position of Hole 633A, the finegrained turbidites in Unit I are unusually thin. These characteristics can be explained by the location of the site on a topographic high that rises $20-40 \mathrm{~m}$ above the surrounding seafloor and could be caused by progradation of a spur of the gullied slope or by large-scale slumping prior to the deposition of Unit I (Austin, Schlager, et al., 1986). For methods (sediment sampling and analyses, carbonate content in fine fraction, carbonate mineralogy, stratigraphy, and oxygen isotope), we refer the reader to Droxler et al. (1988b, pp. 222-223).

\section{METHODS}

\section{Sediment Sampling and Analyses}

The top $108 \mathrm{~m}$ of Hole 716B were sampled every $20 \mathrm{~cm}$ (Appendix A) and the top $19.5 \mathrm{~m}$ of Hole $714 \mathrm{~A}$ every $10 \mathrm{~cm}$ (Appendix B). Sampling the periplatform ooze was simplified because both holes are free of turbidite layers with the exception in Hole 714A of one turbidite layer at 19.0 mbsf (Backman, Duncan, et al., 1988). Care was taken to avoid sampling obviously reworked or disturbed features at the top and bottom of the core. Each $10-\mathrm{cm}^{3}$ sediment sample was dried in an oven at $60^{\circ} \mathrm{C}$, weighed, and suspended in distilled water $(\mathrm{pH} 8)$. The coarse fraction of the sediment was separated from the fine fraction through a $63-\mu \mathrm{m}$ mesh sieve and then dried at $60^{\circ} \mathrm{C}$ and weighed again. The fine fraction $(<63 \mu \mathrm{m})$ was left to stand in distilled water for 1-2 days until the particles were completely 


\section{A World Location Map of Sites Studied}

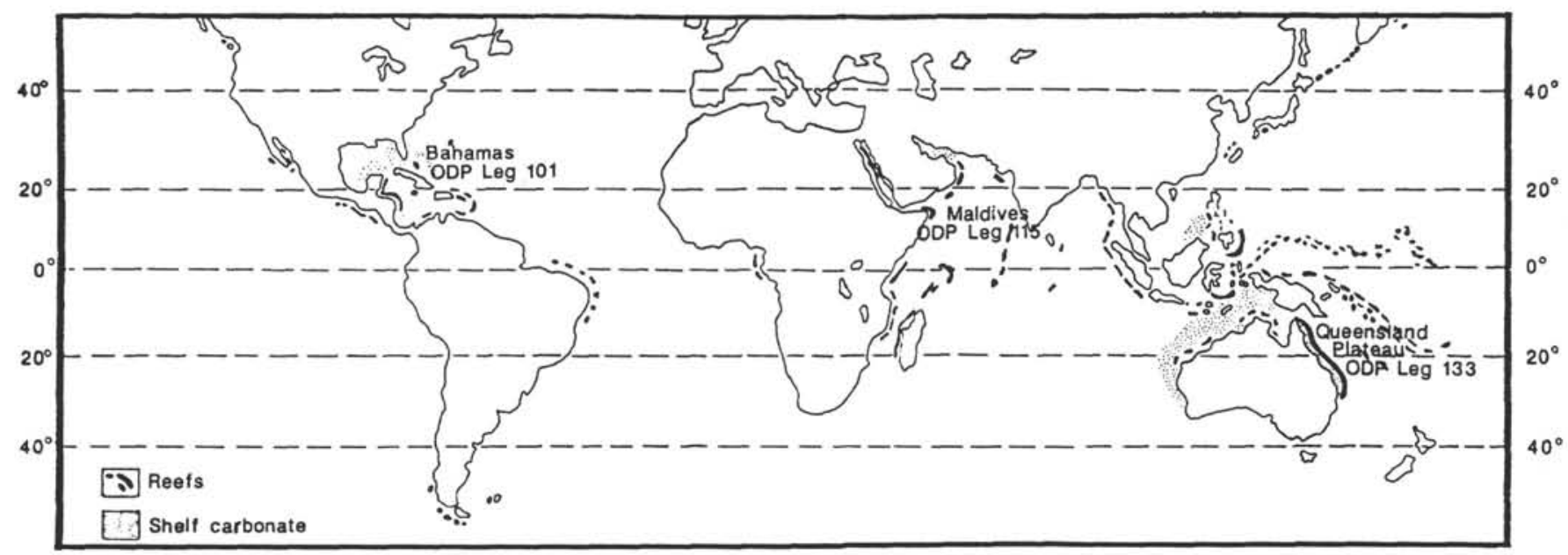

3 Maldives

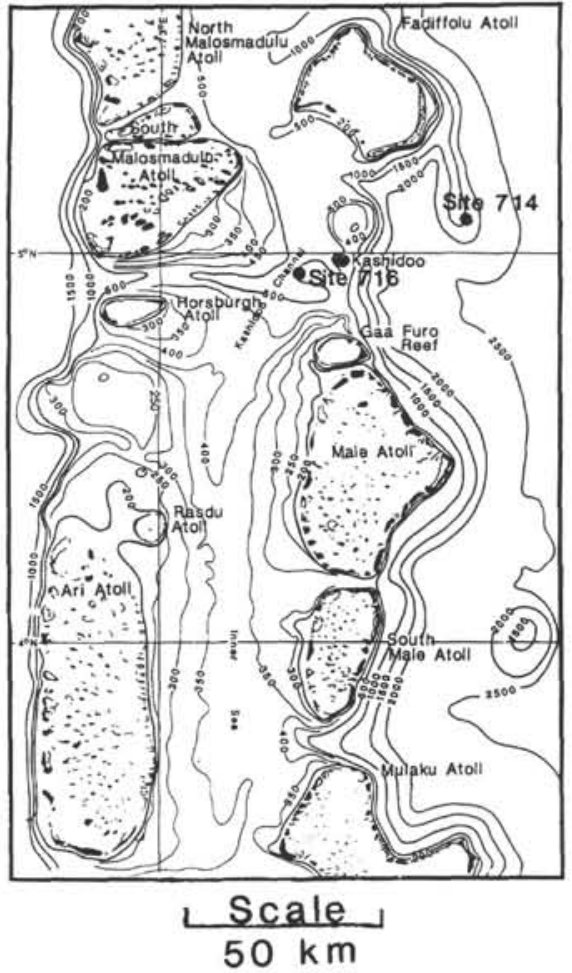

C Bahamas

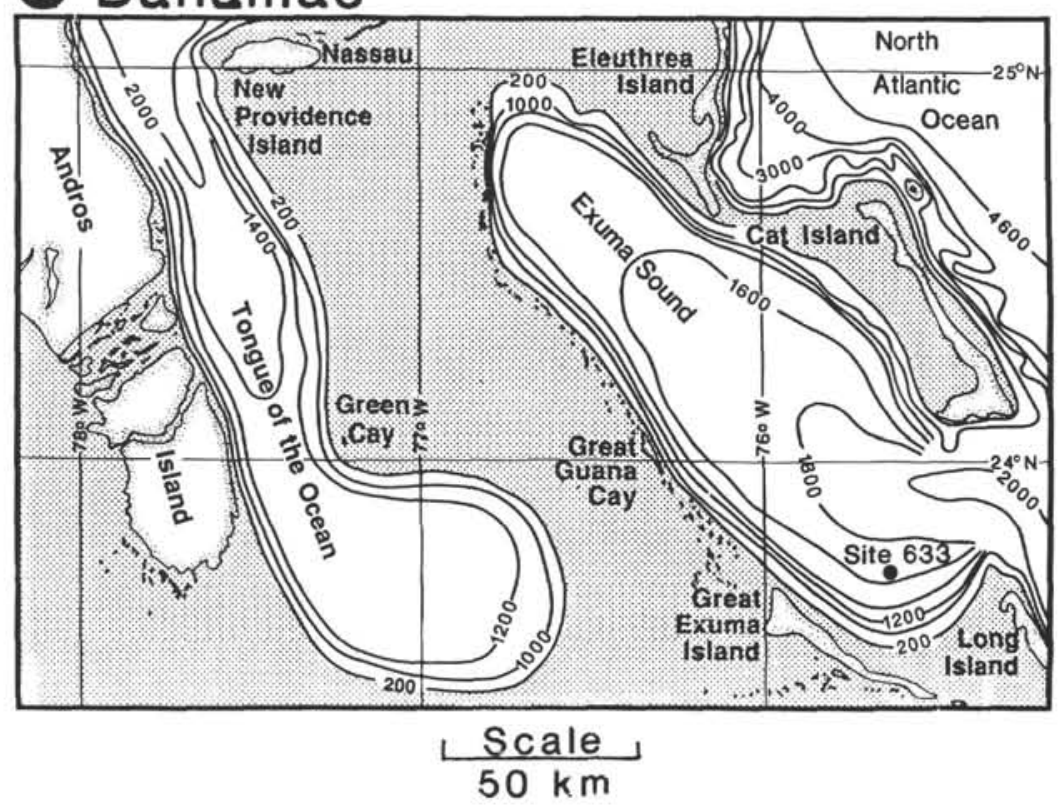

Figure 1. A. World distribution of modern marine shallow-water carbonate systems (modified from Wilson, 1975) with location of ODP Leg 101 in the Bahamas, ODP Leg 115 in the Maldives, and future ODP Leg 133 in northeast Australia. B. Location in the Maldives of Site 714, at the slope base of a ridge, $30 \mathrm{~km}$ southeast of Fadiffolu Atoll (water depth: $2195 \mathrm{~m}$ ), and Site 716 near the middle of Kashidoo Channel (water depth: $540 \mathrm{~m}$ ). C. Location in the Bahamas of Site 633 in the southern part of Exuma Sound (water depth: $1681 \mathrm{~m}$ ). Maps B and C were drawn at the same scale for easy comparison. In the Maldives (Map B), water depths in the major atolls range from $<1$ to $80 \mathrm{~m}$, whereas in the Bahamas (Map C), the Great Bahama Bank (gray area on the map) is covered, on average, by 5-6 m water depths, with maximum depths from 10 to $15 \mathrm{~m}$.

settled and then was dried at $60^{\circ} \mathrm{C}$. The coarse fraction was used to estimate the degrees of cementation and overgrowth, to pick monospecific samples of the planktonic foraminifer Globigerinoides sacculifera for oxygen isotope analyses, and to evaluate pteropod preservation for the top 17.25 mbsf of Hole 716B (down the cores to Sample 115-716B-3H-4, 40-42 cm) (see Cullen and Droxler, this volume, for details). The fine fraction was used for carbonate-mineralogy analyses by X-ray diffraction (XRD) and for carbonate-content analyses by carbonate bomb (Müller and Gastner, 1971).

\section{Carbonate Content in the Fine Fraction}

The carbonate-bomb method was used to determine the total carbonate content of the fine fraction in each sample from the 
$\mathrm{CO}_{2}$ pressure generated by dissolving the carbonate fraction in $50 \%$ concentrated HCL (Müller and Gastner, 1971). The pressure of $\mathrm{CO}_{2}$ released by the fraction of the carbonate with the acid was compared with pressure released by an equal amount of $100 \% \mathrm{CaCO}_{3}$ standard. Accuracy of the method for marine sediments remained within $\pm 2 \%$ for $\mathrm{CaCO}_{3}$ values ranging from $5 \%$ to $95 \%$ (Birch, 1979).

\section{Carbonate Mineralogy of the Fine Fraction}

Relative proportions of the different carbonate minerals were quantified by XRD analyses. Each sample of fine sediment was dried at $60^{\circ} \mathrm{C}$, ground for $<1 \mathrm{~min}$ by hand in an agate mortar, sieved to obtain an agglomerate of $\langle 63-\mu \mathrm{m}$ particles, and packed with a spatula into an aluminum sample holder. The effects of particle size on the semiquantitative XRD estimate and the effects of mineralogy change by grinding are minimized through these procedures (Milliman, 1974). Each sample was analyzed with a Phillips-Norelco Model 12045 (60 cycles) diffractometer with Dapple Systems Controller Thetaplus ${ }^{\otimes}$ Software. The diffractometer setting used was at $35 \mathrm{kV}$ and $20 \mathrm{~mA}$, and the analysis was conducted through a two-segmented scan from $25.5^{\circ}$ to $27.5^{\circ}$ for the aragonite primary peak and from $28.5^{\circ}$ to $32^{\circ}$ for the calcite and dolomite peaks, at a low scanning speed of $0.02 \% \mathrm{~s}$ for optimal resolution. Areas under the aragonite peak, the dolomite peak (if present), and the calcite peaks (calcite and magnesian calcite) separated by deconvolution were calculated by integration of the counts under the respective peak and above the general noise background. The aragonite portion in each sample was calculated with an accuracy of better than $5 \%$ from a calibration curve (Droxler, 1984). Reproducibility of the deconvolution method used to separate calcite from magnesian calcite is within a measured maximum discrepancy of $<5 \%$.

\section{Stratigraphies}

\section{Oxygen Isotopes}

Oxygen isotopes were analyzed on Globigerinoides sacculifera at 20-cm intervals down to Sample 115-716B-5H-6, 60-62 $\mathrm{cm}(36.15 \mathrm{mbsf})$ in Hole $716 \mathrm{~B}$ and down to Sample 115-714A$3 \mathrm{H}-5$ (19.48 mbsf) in Hole 714A, using the same samples in Holes 716B and 714A as were used for fine-fraction studies in the mineralogical studies. For each sample, 20-30 foraminifer tests were picked in a narrow size fraction between 300 and 350 $\mu \mathrm{m}$, cleaned ultrasonically to remove any calcareous mud clinging to the tests, and dried at $60^{\circ} \mathrm{C}$. They were reacted at $50^{\circ} \mathrm{C}$ with excess $100 \% \mathrm{H}_{3} \mathrm{PO}_{4}$, and the $\mathrm{CO}_{2}$ gas was analyzed in a semiautomated VG Micromass $602 \mathrm{E}$ at the Stable Isotope Laboratory of Rice University (R. Dunbar). Results are reported relative to the PDB standard. Analytical precision on standards was better than $0.1 \%$.

\section{Nannostratigraphy}

Nannostratigraphy datums are based on research conducted on board Leg 115 (Backman, Duncan, et al., 1988) and postcruise research by H. Okada, D. Rio, A. Chepstow-Lusty, and J. Backman published in this volume. We refer the reader to their respective articles published in this volume for more details on their respective methodologies.

\section{RAW DATA}

We are calling "raw data" the direct results that come out of the different analyses as applied to the periplatform samples (see "Methods" section, this chapter, for more details). Figures 2, 3, and 4 display the raw data for the top 108 mbsf of Hole 716B, representing the past 3.5 m.y., for the top 19.5 mbsf of Hole $714 \mathrm{~A}$, representing the past $0.55 \mathrm{~m} . \mathrm{y}$.; and for the top 44 mbsf of Hole 633A, representing the past $2.1 \mathrm{~m}$.y., respectively.

\section{Proportion of the Fine Fraction}

\section{Hole $716 B$}

Downcore variations of the fine fraction proportions in Hole 716B display a high-frequency cyclic pattern (Fig. 2A). The 110m-long periplatform sequence can be divided into three segments according to the average values and amplitudes of the variations. In the upper segment (0-31 mbsf) of Hole 716B, values of fine fraction content average $40 \%$, ranging from $25 \%$ to $65 \%$; in the middle segment (31-85 mbsf), they average $50 \%$, ranging from $40 \%$ to $75 \%$; and in the lower segment (85-110 mbsf) they average $40 \%$, ranging from $30 \%$ to $60 \%$. The average amplitude of the cyclic pattern for each segment thus decreases downcore from $40 \%$ to $35 \%$, and finally to $30 \%$. Minimum values, ranging from $10 \%$ to $20 \%$, are concentrated within a few meters, centered around $30 \mathrm{mbsf}$. This particular level corresponds to a distinct event that separates the early Pleistocene from the middle.

\section{Hole $714 A$}

Fine fraction values average $45 \%$, ranging from $25 \%$ to $70 \%$ in the upper $19.5 \mathrm{~m}$ of Hole 714A (Fig. 3A), and are therefore quite similar to the values in the upper segment of Hole 716B.

\section{Hole 633A}

Fine fraction values in the top $40 \mathrm{~m}$ of Hole 633A (Fig. 4A) always remain higher than the values observed in Holes 714A and $716 \mathrm{~B}$. They average $82 \%$, ranging from $70 \%$ to $90 \%$, and remain relatively constant in the top $30 \mathrm{~m}$; they average $70 \%$, ranging from $40 \%$ to $90 \%$, for the lower $14 \mathrm{~m}$ of the section. The lowest fine fraction values occur mainly during the late Pliocene and at the beginning of the early Pleistocene at levels where foraminifer tests display partial overgrowths and where agglomerates of periplatform sediments are common. In other words, the low values of the fine fraction or the high values of the coarse fraction can be explained in these cases by diagenesis through early cementation.

\section{Carbonate Content in the Fine Fraction}

\section{Hole $716 B$}

The top $108 \mathrm{~m}$ of Hole $716 \mathrm{~B}$ can be easily separated into two segments (Fig. 2B). The lower segment, from 30 to $108 \mathrm{mbsf}$, is characterized by high carbonate values and low (5\%) amplitude variations; average values vary from $91 \%$ at $30 \mathrm{mbsf}, 96 \%$ at 40 mbsf, and $93 \%$ between 50 and 110 mbsf. The upper 30-m-long segment contrasts drastically with the lower segment. The upper segment is characterized by low carbonate values, ranging from $96 \%$ to $83 \% ; 10 \%$ amplitude cyclic variations; and a systematic decrease of the average carbonate values from $91 \%$ at $30 \mathrm{mbsf}$ to $87 \%$ mbsf in the surface sediments. As already observed in the fine fraction variations, the 30 -mbsf level of Hole $716 \mathrm{~B}$, which corresponds to the early/middle Pleistocene boundary, shows a drastic change in the carbonate values within the fine fraction. At that level, irregular low-amplitude cyclic carbonate variations with high carbonate values suddenly change into regular high-amplitude carbonate cycles, with average values gradually decreasing toward the surface sediments.

\section{Hole $714 A$}

Carbonate values in the fine fraction of the top $19.5 \mathrm{~m}$ in Hole 714A (Fig. 3B) range between $40 \%$ and $80 \%$, and their variations display regular cycles, similar to the ones observed in the top $30 \mathrm{~m}$ of Hole $716 \mathrm{~B}$, but with higher amplitudes $(30 \%$ instead of $10 \%$ ) and lower average carbonate values decreasing systematically from $70 \%$ at 20 mbsf to $60 \%$ in the surface sediments. 

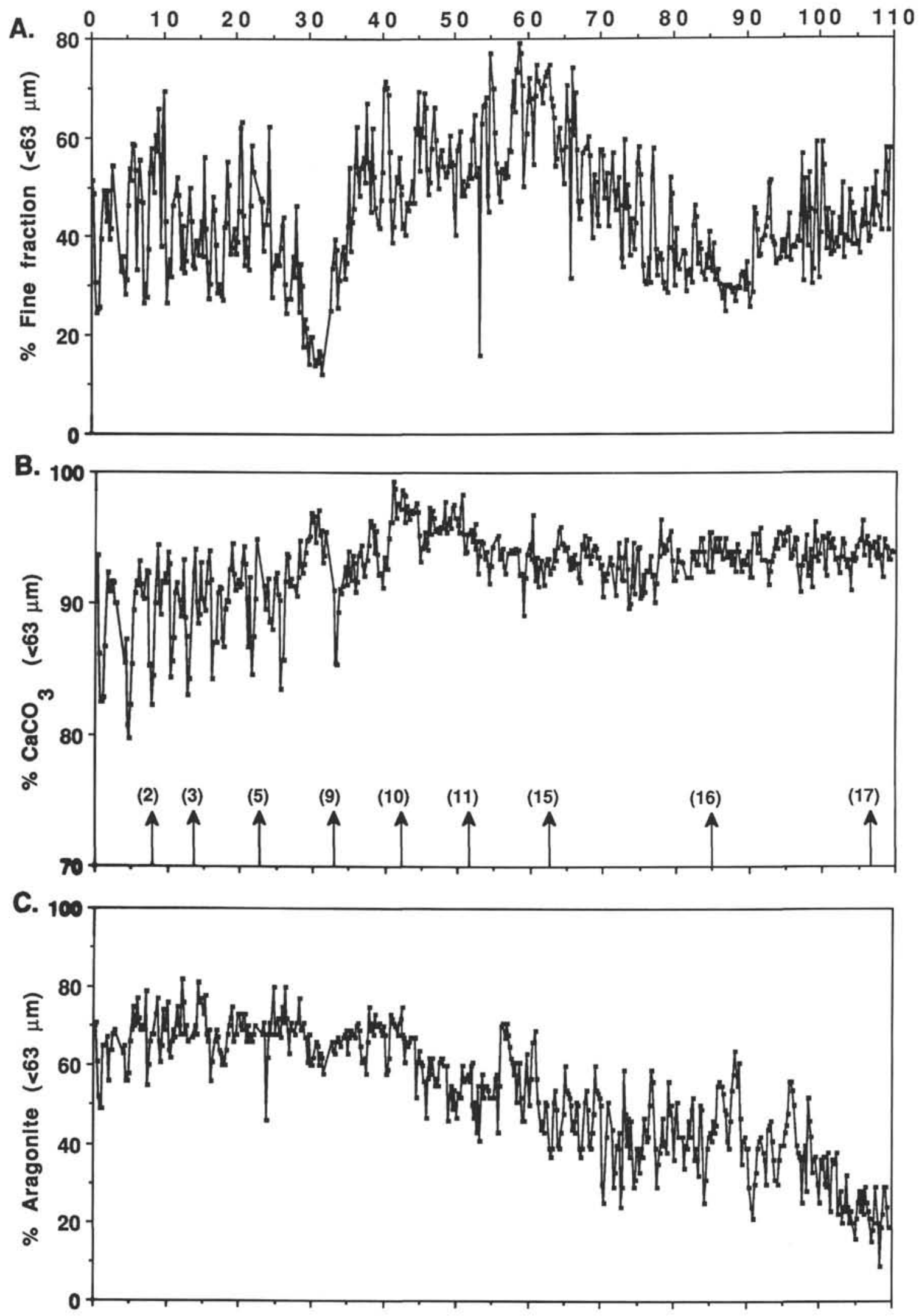

Figure 2. Depth variations for the top $108 \mathrm{~m}$ of Hole 716B of (A) the fine fraction, (B) the $\mathrm{CaCO}_{3}$ content in the fine fraction, (C) aragonite and (D) magnesian calcite content in the carbonate fraction of the fine fraction, and (E) the planktonic $\delta^{18} \mathrm{O}$ record of Globigerinoides sacculifera. The numbers in parentheses refer to the datum levels based on nannofossil stratigraphy; see Table 2 for corresponding datum levels. 

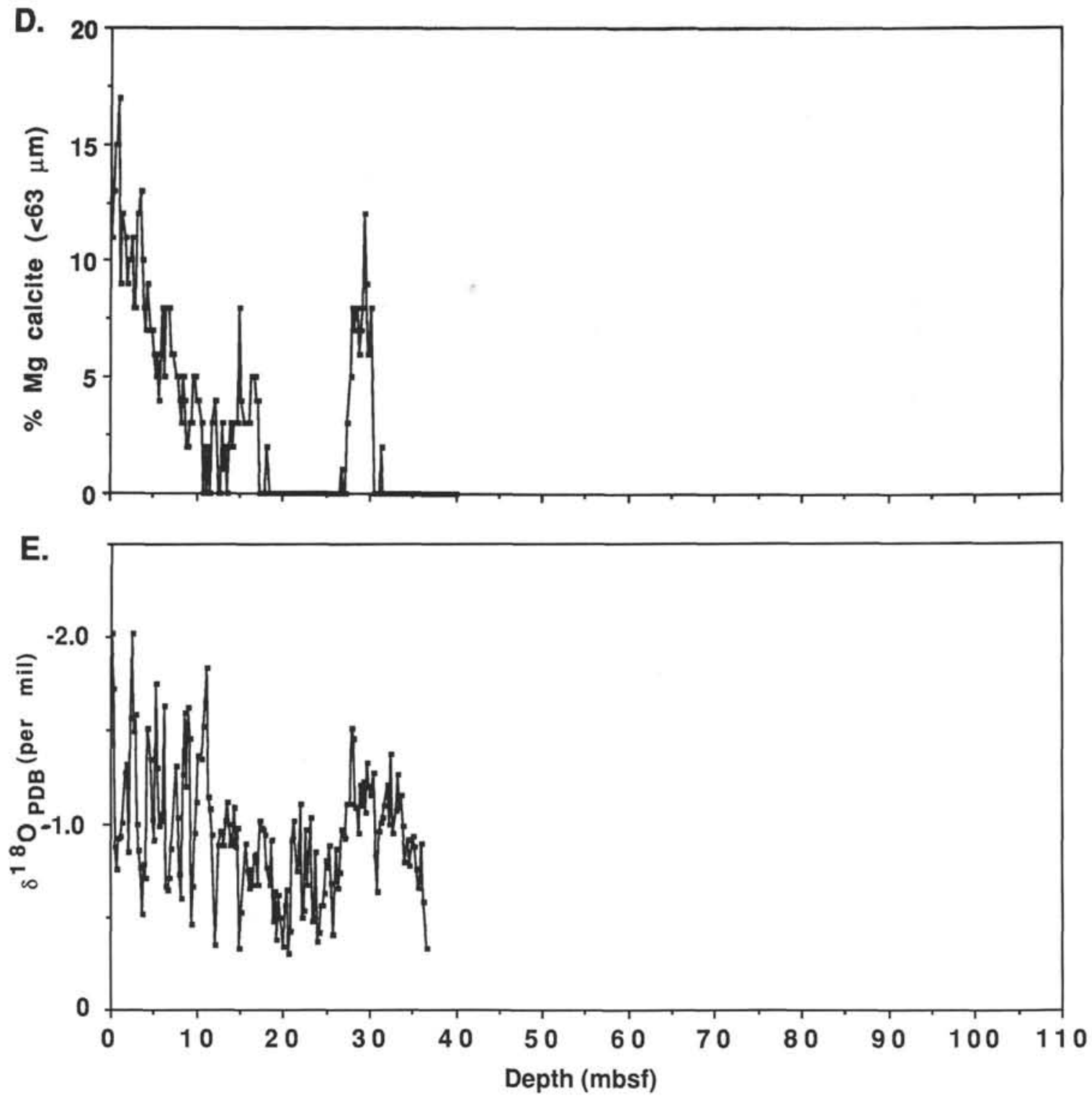

Figure 2 (continued).

\section{Hole 633A}

Average carbonate values in the top $44 \mathrm{~m}$ of Hole $633 \mathrm{~A}$ (Fig. 4B) oscillate between $95 \%$ and $90 \%$. Values lower than $90 \%$ correspond in the upper $20 \mathrm{~m}$ of Hole $633 \mathrm{~A}$ to clay-rich layers that can easily be observed visually by color change on the core surface (Droxler et al., 1988b). Variations of the carbonate values have a cyclic, but quite irregular, character, especially when one compares them with the regular well-defined carbonate cycles in the top $30 \mathrm{~m}$ of Hole 716B.

\section{Aragonite Content in the Fine Carbonate Fraction}

\section{Hole $716 B$}

Average aragonite values for Hole 716B (Fig. 2C) vary from $60 \%$ within the surface sediment to $25 \%$ at the bottom $(110$ mbsf), reaching a maximum of $65 \%$ between 10 and 25 mbsf. Absolute aragonite values range from $80 \%$ at 10 mbsf to $10 \%$ at 110 mbsf. A rough cyclic pattern can be detected within the downcore aragonite variations. Amplitudes of the aragonite cycles vary downcore in Hole 716B, ranging from a few percent to $10 \%-15 \%$. The largest amplitude of the aragonite cycles occur in the bottom half and in the top $10 \mathrm{~m}$ of Hole 716B.

\section{Hole $714 A$}

Aragonite absolute values vary between $0 \%$ and $65 \%$ in the top $19.5 \mathrm{~m}$ of Hole $714 \mathrm{~A}$ and display a regular cyclic pattern (Fig. 3C). Maximum aragonite values for each cycle decrease downcore, from $65 \%$ for the three most recent peaks, to $50 \%$ for the previous two peaks, and finally to $40 \%$ for the oldest peak recorded in Hole 714A. The amplitudes of the aragonite cycles as well as the length of intervals without aragonite also increase downcore.

\section{Hole 633A}

Variations of aragonite content display a regular cyclic pattern within the top $35 \mathrm{~m}$ of Hole 633A (Fig. 4C). Amplitudes of these cycles are highly variable, ranging from $20 \%$ to $75 \%$. Be- 

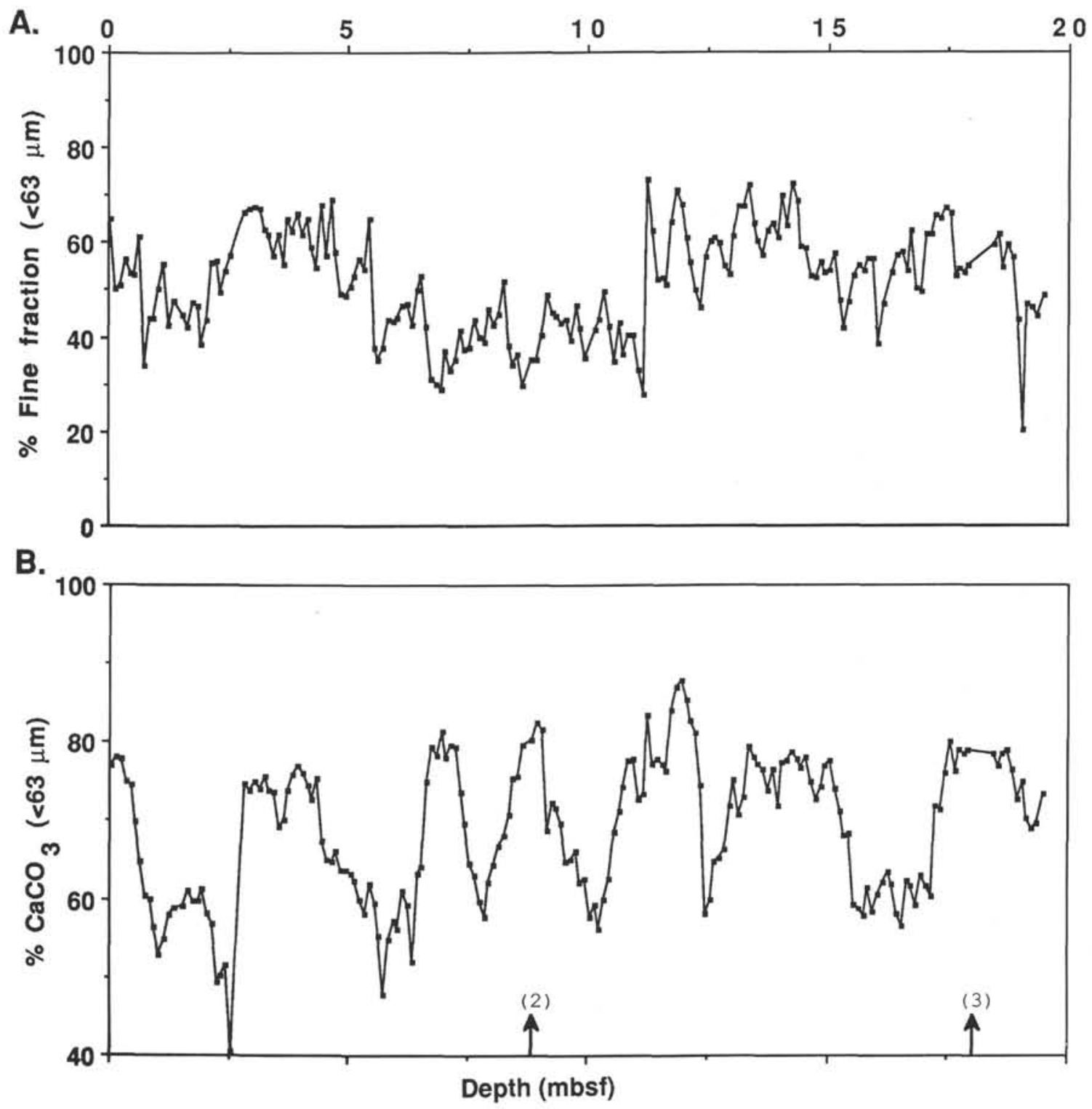

Figure 3. Depth variations for the top $19.5 \mathrm{~m}$ of Hole $714 \mathrm{~A}$ of (A) the fine fraction, (B) the $\mathrm{CaCO}_{3}$ content in the fine fraction, (C) aragonite content in the carbonate fraction of the fine fraction, and (D) planktonic $\delta^{18} \mathrm{O}$ record of Globigerinoides sacculifera. The numbers in parentheses refer to the datum levels based on nannofossil stratigraphy; see Table 2 for corresponding datum levels.

low 35 mbsf, aragonite disappears in several intervals. Aragonite cycles in Hole 633A have been fully described in Droxler et al. (1988b).

\section{Magnesian Calcite in Fine Carbonate Fraction}

\section{Hole $716 B$}

Values of magnesian calcite content within the fine carbonate fraction decrease downcore from a maximum of $15 \%$ close to the top of Hole 716B to $0 \%$ at 11 mbsf (Fig. 2D). Magnesian calcite reappears twice as isolated peaks, the shallowest one centered at 15 mbsf (average magnesian calcite content value of $3 \%$ ), and the second one centered at $19 \mathrm{mbsf}$ (average magnesian calcite value of $7 \%$ ).

\section{Hole $714 A$}

Magnesian calcite was not detected in any of the analyzed samples from Hole 714A.

\section{Hole $633 A$}

The resemblance between the downcore variations of magnesian calcite in Hole $633 \mathrm{~A}$ and Hole $716 \mathrm{~B}$ is quite striking. In Hole 633A (Fig. 4D), magnesian calcite content is at its maximum ( $15 \%$ close to its top) and then decreases regularly to reappear within two intervals, centered at 13 and $10 \mathrm{mbsf}$ (see Droxler et al., 1988b).

\section{Oxygen Isotope Record}

\section{Hole $716 B$}

The oxygen isotope record shows well-developed cycles with high amplitudes $(1.3 \% 0-1.5 \%)$ in the top $12 \mathrm{~m}$, and then with fairly low amplitudes $(0.75 \%$ ) further down the hole. This record mimics both classic $\delta^{18} \mathrm{O}$ records and the SPECMAP smoothed stack record. Comments on the oxygen isotopic re- 

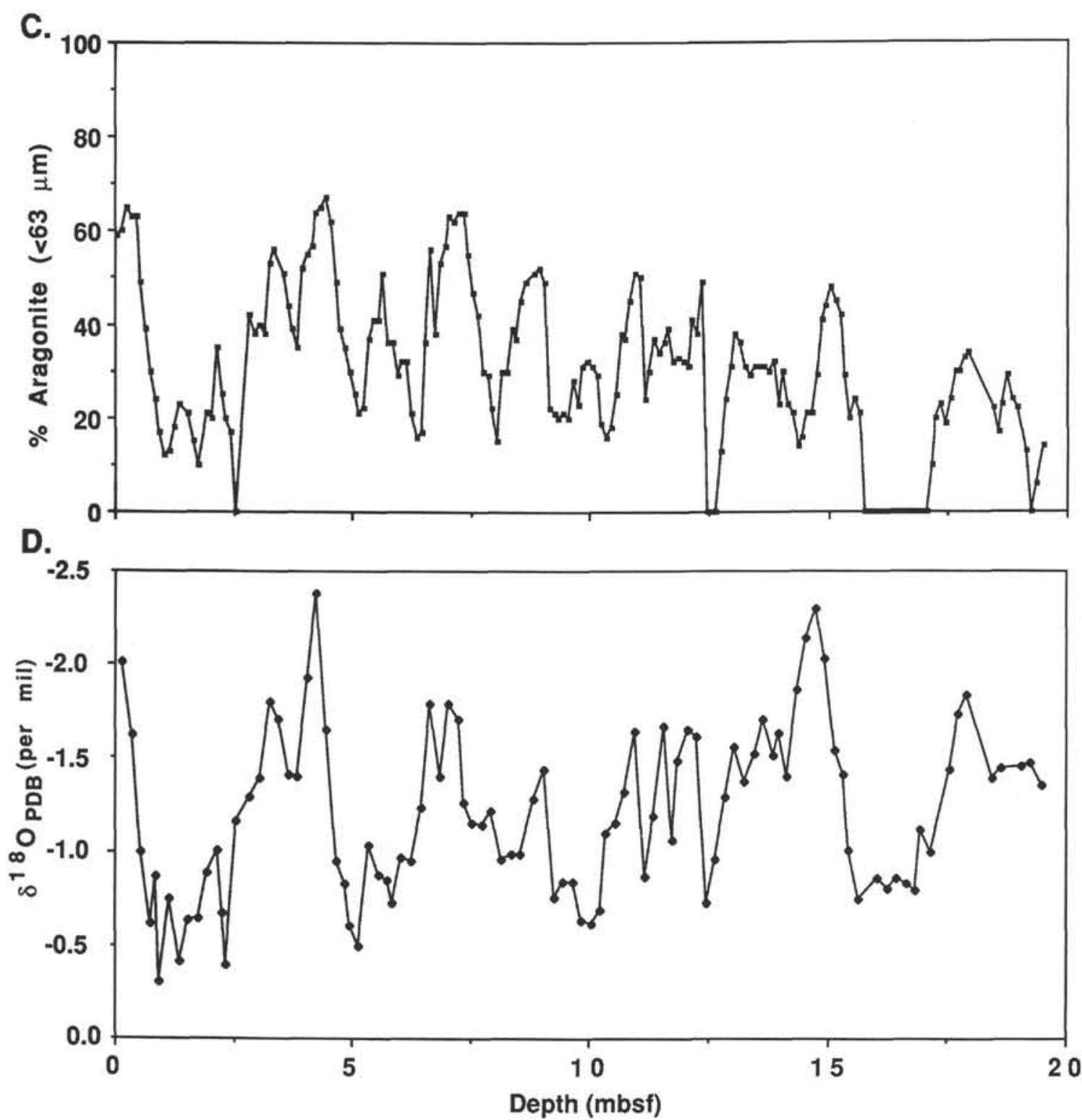

Figure 3 (continued).

cord are expanded in the "Isotope Stratigraphy" section (this chapter).

\section{Hole $714 A$}

In the top $19.5 \mathrm{~m}$ of Hole $714 \mathrm{~A}$, the $\delta^{18} \mathrm{O}$ record shows welldeveloped cyclic variations, with signal amplitudes ranging from $1.0 \%$ to $1.7 \%$, and corresponding to the $\delta^{18} \mathrm{O}$ record of the top $17 \mathrm{~m}$ in Hole 716B (Fig. 3E).

\section{Hole $633 A$}

The $\delta^{18} \mathrm{O}$ record for the top $44 \mathrm{~m}$ of Hole 633A (Fig. $4 \mathrm{E}$ ) is from Droxler et al. (1988a). This record is mainly based on Globigerinoides sacculifera with a few analyses performed on Globigerinoides rubra in the top $10 \mathrm{~m}$ of the hole (see Droxler et al., 1988 b, for more detail).

The three $\delta^{18} \mathrm{O}$ records from Holes 716B, 714A, and 633A will serve as a basis on which to establish a time scale for the last $1.1 \mathrm{~m}$.y. by comparing them with the SPECMAP $\delta^{18} \mathrm{O}$ record of Imbrie et al. (1984) and the composite $\delta^{18} \mathrm{O}$ record of Williams et al. (1988).

\section{TIME SCALE IN HOLES 716B, 714A, AND 633A}

The chronology developed for the three holes is based on nannofossil stratigraphy $(716 \mathrm{~B}, 714 \mathrm{~A}$, and 633A), magnetostratigraphy (633A), Globorotalia menardii complex stratigraphy $(633 \mathrm{~A})$, and oxygen isotope stratigraphy in Holes $716 \mathrm{~B}$ and $633 \mathrm{~A}$ for the last $1.1 \mathrm{~m} . \mathrm{y}$, , and in Hole $714 \mathrm{~A}$ for the last 0.55 m.y.

Late and Middle Pleistocene: 0-1.1 Ma, Holes 716B and 633A, and 0-0.55 Ma, Hole 714A

Our time scale for the last million years (more precisely, from 0 to $1.05 \mathrm{Ma}$ ) is based mainly on the identification of the oxygen isotope stages from the planktonic records that we generated for Holes $716 \mathrm{~B}, 714 \mathrm{~A}$, and $633 \mathrm{~A}$ by comparing them with such records as V28-239 (Shackleton and Opdyke, 1976), DSDP Site 502 (Prell, 1982), and DSDP 607 (Ruddiman et al., 1987), and with the smoothed-stack $\delta^{18} \mathrm{O}$ record of Imbrie et al. (1984) and the composite $\delta^{18} \mathrm{O}$ record of Williams et al. (1988). Sedimentation rates are assumed to be constant for each particular 

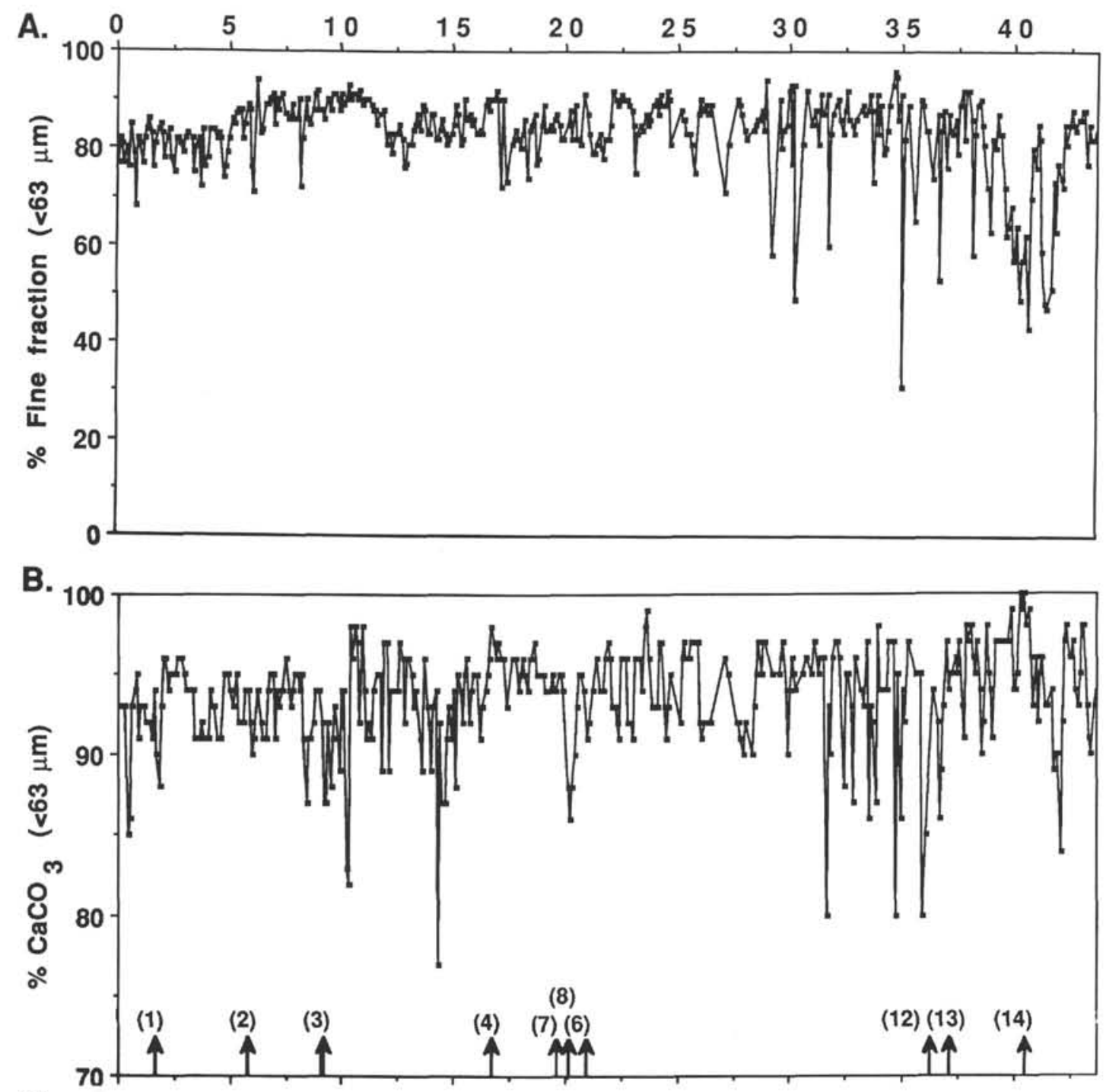

C.

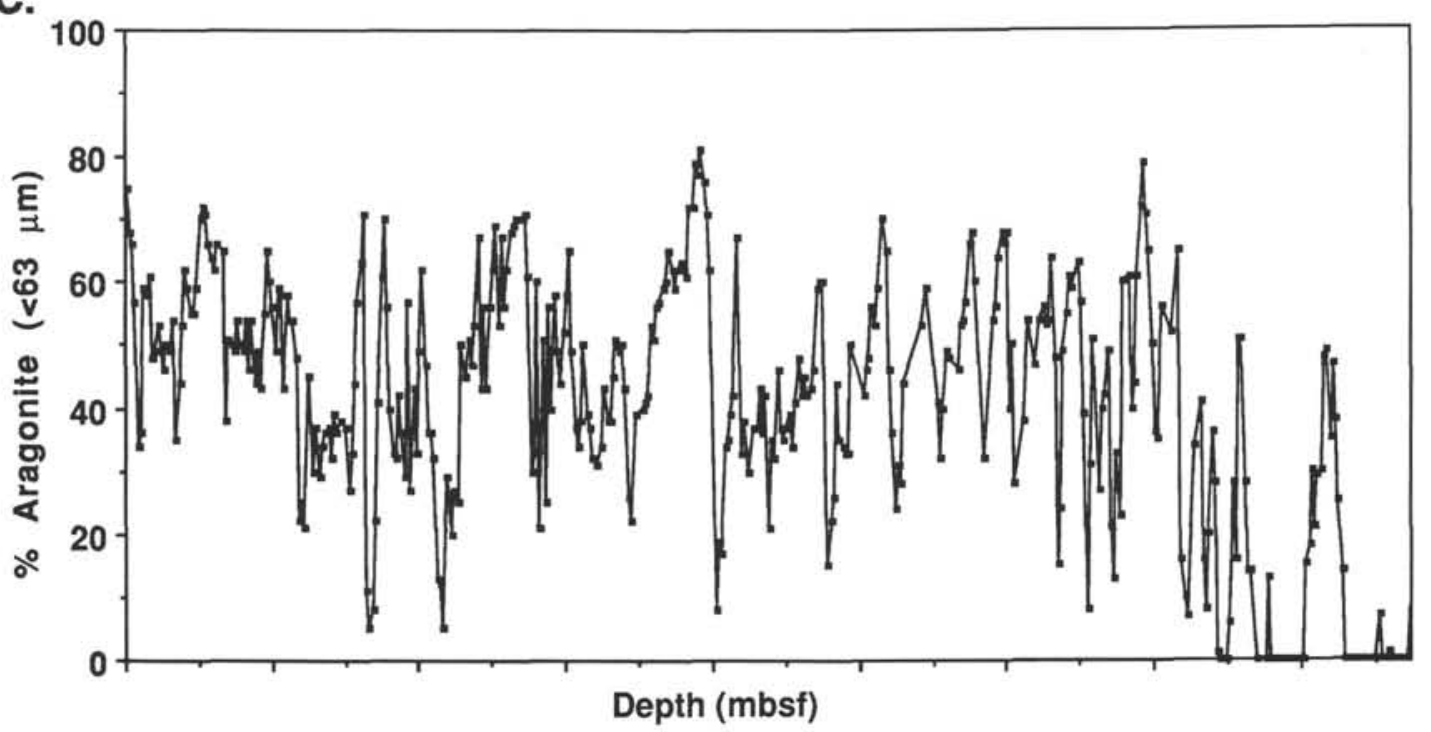

Figure 4. Depth variations for the top $43.5 \mathrm{~m}$ of Hole $633 \mathrm{~A}$ of $(\mathbf{A})$ the fine fraction, $(\mathbf{B})$ the $\mathrm{CaCO}_{3}$ content in the fine fraction, (C) aragonite and (D) magnesian calcite content in the carbonate fraction of the fine fraction, and (E) the planktonic record based mainly on Globigerinoides sacculifera, with some analyses done on Globigerinoides rubra in the top $8 \mathrm{~m}$ of Hole $633 \mathrm{~A}$. The numbers in parentheses refer to the datum levels based on nannofossil and magnetic stratigraphies; see Table 2 for corresponding datum levels. 

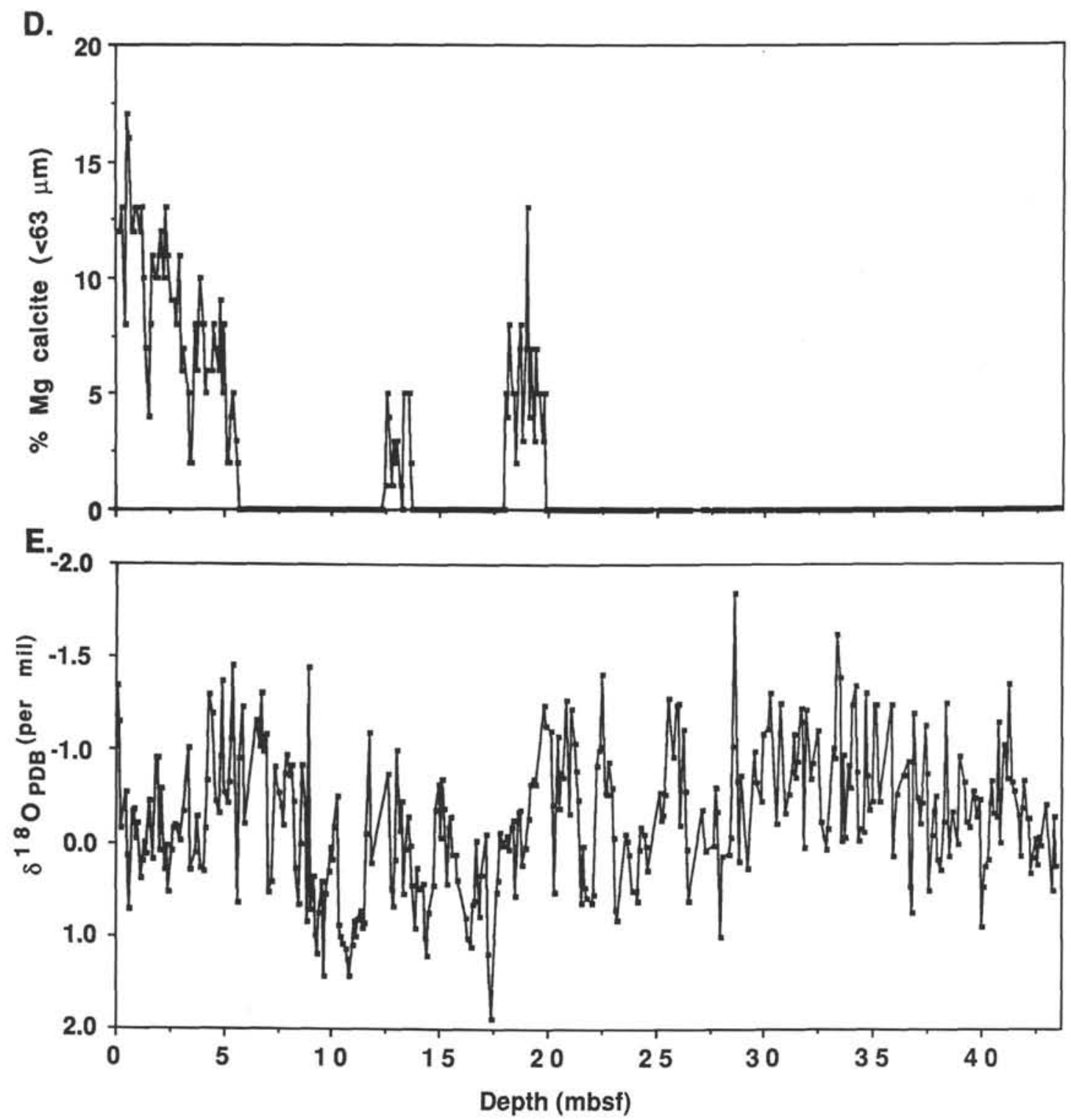

Figure 4 (continued).

isotope stage. The chronology of $\delta^{18} \mathrm{O}$ stage boundaries developed by Imbrie et al. (1984) is used for the last $0.8 \mathrm{~m}$.y., corresponding to the Stage $21 / 22$ boundary, and the chronology developed by Williams et al. (1988) for the time interval between 0.8 and $1.1 \mathrm{Ma}$, applying some modifications of the stage numbers used by Williams et al. (1988). Figure 5 shows $\delta^{18} \mathrm{O}$ chronologies based on Imbrie et al. (1984) and Williams et al. (1988). Discrepancies between the two chronologies are quite significant and range between $\sim 37$ and 24 k.y. (see Table IX in Williams et al., 1988) within the past $0.8 \mathrm{~m}$.y. The discrepancy between the time scales for the isotope Stage $21 / 22$ boundary is quite small ( $\sim 0.4$ k.y.). Preference was given to Imbrie's chronology for oxygen isotope stage boundaries down to the Stage $21 / 22$ boundary, since the papers to which we refer in our discussion have used the Imbrie et al. (1984) time scale. Further back in time, we have relied on the time scale of Williams et al. (1988). We have, however, maintained the stage numbers published by Shackleton and Opdyke (1976) on V28-239 and by Prell (1982) on DSDP Site 502, where the Stage 23/24 boundary is defined as the upper boundary $(0.92 \mathrm{Ma}$; Harland et al., 1982) of the normal polarity Jaramillo Subchron. In this paper, our Stage 23 includes Stages 23-27 of Williams et al. (1988). Our Stage 24 becomes their Stage 28 , and our Stage 26 is equivalent to their Stage 32. In summary, our Stage 23/24, 24/25, and $25 / 26$ boundaries are equivalent to the Stage $27 / 28,28 / 29$, and $31 / 32$ boundaries, respectively, of Williams et al. (1988) and their individual ages, therefore, are $0.917,0.930$, and 1.007 Ma (Fig. 5 and Table 1).

Figure 6 shows a comparison of the SPECMAP smoothedstack $\delta^{18} \mathrm{O}$ record with the three $\delta^{18} \mathrm{O}$ records of this study plotted vs. time, including the $1.1-\mathrm{Ma} \delta^{18} \mathrm{O}$ records for Holes $633 \mathrm{~A}$ and $716 \mathrm{~B}$, and the $0.55-\mathrm{Ma} \delta^{18} \mathrm{O}$ record for Hole $714 \mathrm{~A}$. In this comparative diagram, the correlation between the different records, although at a few levels somewhat laborious, gives an insight into the quality of the $\delta^{18} \mathrm{O}$ stratigraphy that can be applied to the three ODP sites of this study. Figure 7 shows depth vs age in the time scale based on $\delta^{18} \mathrm{O}$ stratigraphy for the three sites analyzed in this paper. In Hole 716B (Fig. 7A), the available nannofossil datums (Table 2) plot quite well within the $\delta^{18} \mathrm{O}$ time frame: datums 5 and 10 are somewhat off, but they have not been defined globally as have datums 2 and 3 (Thierstein et al., 1977). In Hole 714A (Fig. 7B), datums 2 and 3 (Table 2) fall 


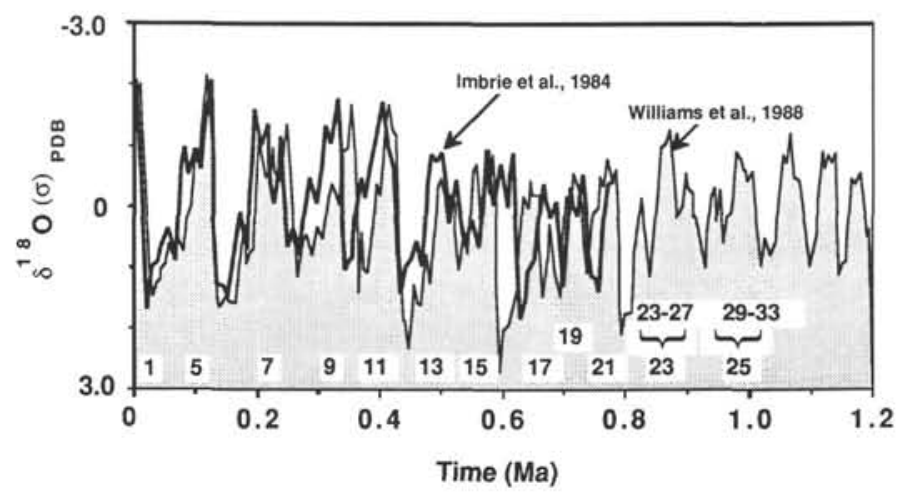

Figure 5. Comparison of mean linear interpolation ages (Williams et al., 1988) and SPECMAP ages (Imbrie et al., 1984) for stage boundaries, including the Stage $21 / 22$ boundary $(0.80 \mathrm{Ma})$. The stage numbers used in this paper are included. Stages 23,24 , and 25 , which are identified in this paper, correspond to Stages $23-27,28$, and 29-33, respectively, of Williams et al. (1988).

close to the $\delta^{18} \mathrm{O}$ time frame (within $1.5 \mathrm{~m}$ ). In Hole 633A (Fig. 7C), datums based on nannofossil stratigraphy and magnetostratigraphy are available (Table 2) and show that the $\delta^{18} \mathrm{O}$ time frame is correct. On the basis of Figure $7 \mathrm{~A}-7 \mathrm{C}$, general sedimentation rates remain quite constant for the last $1.1 \mathrm{~m}$.y., even though sedimentation rates during interglacial stages are much higher than during glacial stages.

\section{Early Pleistocene-Pliocene: 1.0-3.5 Ma, Hole 716B, and 1.0-2.15 Ma, Hole 633A}

Because a $\delta^{18} \mathrm{O}$ record is not yet available for Hole $716 \mathrm{~B}$ and because it is difficult to identify on the $\delta^{18} \mathrm{O}$ record in Hole $633 \mathrm{~A}$ the different stages that Williams et al. (1988) have numbered in their composite record for the early Pleistocene, the time scale for the early Pleistocene and late Pliocene is based on
Table 1. Isotope stage boundaries with corresponding ages and core depths for Holes 714A and 716B (Maldives) and Hole 633A (Bahamas).

\begin{tabular}{|c|c|c|c|c|}
\hline \multirow{2}{*}{$\begin{array}{l}\text { Isotope } \\
\text { stages }\end{array}$} & \multirow{2}{*}{$\begin{array}{l}\text { Age } \\
(\mathrm{Ma})\end{array}$} & \multicolumn{3}{|c|}{ Depth (mbsf) } \\
\hline & & Hole 716B & Hole $714 \mathrm{~A}$ & Hole $633 \mathrm{~A}$ \\
\hline $1 / 2$ & 0.012 & 0.50 & 0.65 & 0.40 \\
\hline $2 / 3$ & 0.024 & 1.00 & 1.45 & 0.50 \\
\hline $3 / 4$ & 0.059 & 2.00 & 2.20 & 1.75 \\
\hline $4 / 5$ & 0.710 & 2.20 & 2.45 & 1.95 \\
\hline $5 / 6$ & 0.128 & 4.10 & 4.50 & 3.60 \\
\hline $6 / 7$ & 0.186 & 5.20 & 6.20 & 4.30 \\
\hline $7 / 8$ & 0.245 & 7.45 & 9.15 & 5.90 \\
\hline $8 / 9$ & 0.303 & 8.45 & 10.40 & 6.70 \\
\hline $9 / 10$ & 0.339 & 10.40 & 12.35 & 8.30 \\
\hline $10 / 11$ & 0.362 & 11.30 & 12.70 & 8.90 \\
\hline $11 / 12$ & 0.423 & 12.75 & 15.30 & 9.20 \\
\hline $12 / 13$ & 0.478 & 13.60 & 16.50 & 9.75 \\
\hline $13 / 14$ & 0.524 & 16.10 & 19.00 & 10.30 \\
\hline $14 / 15$ & 0.565 & 16.75 & - & 11.55 \\
\hline $15 / 16$ & 0.620 & 20.00 & - & 13.75 \\
\hline $16 / 17$ & 0.659 & 22.05 & - & 14.80 \\
\hline $17 / 18$ & 0.689 & 23.80 & - & 15.80 \\
\hline $18 / 19$ & 0.726 & 24.45 & - & 16.70 \\
\hline $19 / 20$ & 0.736 & 25.60 & - & 17.20 \\
\hline $20 / 21$ & 0.763 & 26.35 & - & 17.80 \\
\hline $21 / 22$ & 0.790 & 27.30 & - & 18.50 \\
\hline $22 / 23$ & 0.813 & 28.20 & - & 19.05 \\
\hline $23 / 24(27 / 28)^{\mathrm{a}}$ & 0.917 & 32.75 & - & 20.15 \\
\hline $24 / 25(28 / 29)^{a}$ & 0.930 & 33.90 & - & 20.40 \\
\hline $25 / 26(29 / 30)^{a}$ & 1.007 & 36.40 & - & 21.50 \\
\hline $26 / 27(30 / 31)^{a}$ & 1.043 & 38.60 & - & 22.20 \\
\hline
\end{tabular}

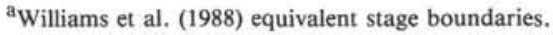

the most accepted nannofossil datums $(11,15,16$, and 17; Table 2) available for Hole $716 \mathrm{~B}$, and on magnetostratigraphy (normal polarity Olduvai Subchron upper and lower boundaries 13 and 14) and nannofossil datum 12 (Table 2) available for Hole 633A. Based on Figures 7A and 7C, sedimentation rates drop by almost a factor of 2 during the late Pliocene in Holes 716B and
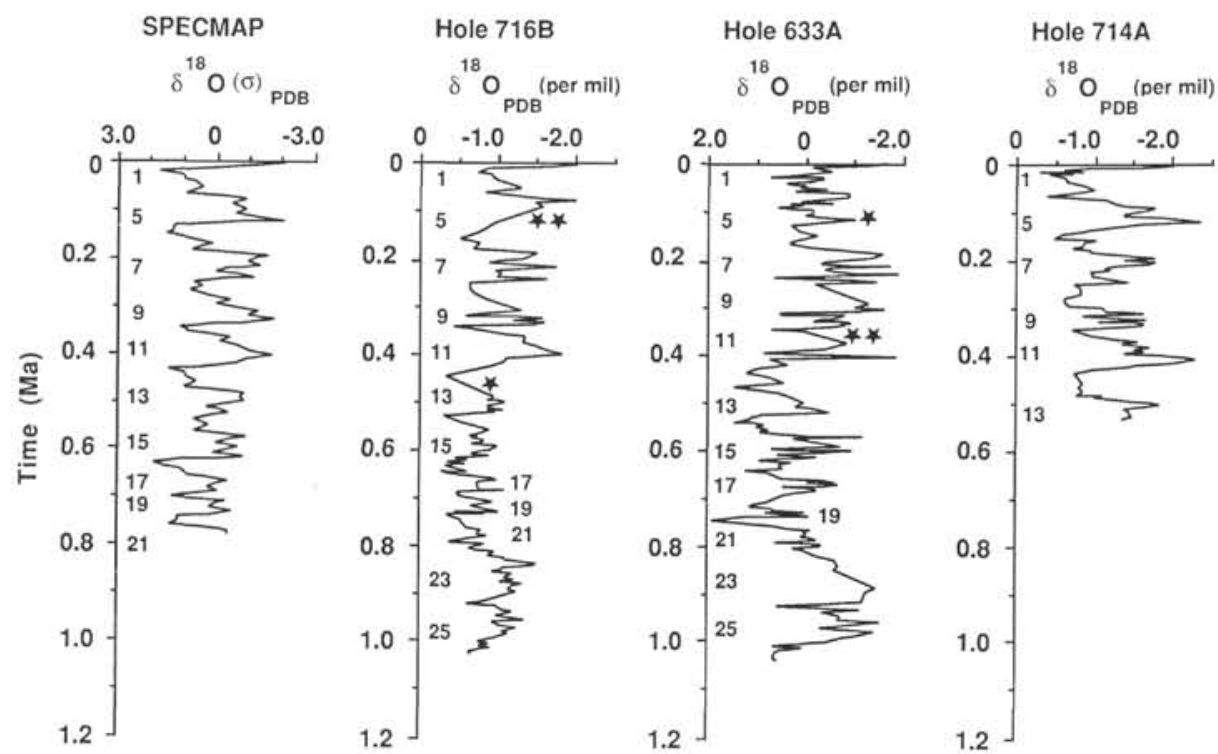

Figure 6. Comparison between SPECMAP smoothed $\delta^{18} \mathrm{O}$ record (Imbrie et al., 1984) and the planktonic $\delta^{18} \mathrm{O}$ records in Holes 716B, 633A, and 714A. Core-depth conversion to time is based on the identification of the oxygen-isotope stages in comparison with the SPECMAP $\delta^{18} \mathrm{O}$ record and the use of ages for stage boundaries down to the $21 / 22$ stage boundary from Imbrie et al. (1984). For earlier stages, boundary ages are from Williams et al. (1988) applied to their modified stage numbers (see text for details; selected ages for stage boundaries are included in Table 1). Sedimentation rates are assumed to be constant for each stage. ${ }^{*}=0.2-0.5-\mathrm{m}$ hiatus; ${ }^{* *}=0.5-1.0-\mathrm{m}$ hiatus. 
Table 2. Age controls for Holes 714A and 716B (Maldives) and Hole 633A (Bahamas).

\begin{tabular}{|c|c|c|c|c|}
\hline \multirow{2}{*}{$\begin{array}{l}\text { Age } \\
\text { (Ma) }\end{array}$} & \multirow[b]{2}{*}{ Datum levels } & \multicolumn{3}{|c|}{ Depth (mbsf) } \\
\hline & & Hole 716B & Hole 714A & Hole $633 \mathrm{~A}$ \\
\hline 0.08 & (1) E. huxleyi Acme Zone & - & - & 2.05 \\
\hline 0.27 & (2) FO E. huxleyi & 8.90 & 8.85 & 6.00 \\
\hline 0.46 & (3) LO $P$. lacunosa & 14.65 & 18.00 & 9.00 \\
\hline 0.73 & (4) Brunhes/Matuyama boundary & - & - & 17.11 \\
\hline 0.82 & (5) Reticulofenestra sp. A (L) & 23.90 & - & - \\
\hline 0.92 & $\begin{array}{l}\text { (6) Gephyrocapsa oceanica } \\
\text { rejuvenation }\end{array}$ & - & - & 21.10 \\
\hline 0.92 & $\begin{array}{l}\text { (7) Matuyama/upper Jaramillo } \\
\text { boundary }\end{array}$ & - & - & 19.50 \\
\hline 0.97 & (8) lower Jaramillo/Matuyama & - & - & 20.15 \\
\hline 1.10 & (9) LO large G. oceanica & 34.45 & - & - \\
\hline $1.29-1.36$ & (10) FO large $G$. oceanica & 43.20 & - & - \\
\hline $1.45-1.46$ & (11) LO Calcidiscus macintyrei & 52.30 & 一 & - \\
\hline 1.6 & (12) FO G. caribbeanica & & - & 36.40 \\
\hline 1.67 & (13) upper Olduvai boundary & - & - & 37.65 \\
\hline 1.87 & (14) lower Olduvai boundary & - & - & 40.65 \\
\hline 1.89 & (15) LO D. brouweri & 62.95 & - & - \\
\hline 2.35 & (16) LO $D$. pentaradiatus & 85.25 & - & - \\
\hline 3.45 & (17) LO Sphenolithus sp. & 106.00 & - & - \\
\hline
\end{tabular}

Note: $\mathrm{FO}=$ first occurrence and $\mathrm{LO}=$ last occurrence.

633A. In Hole $716 \mathrm{~B}$, sedimentation rates drop from 36 to $19 \mathrm{~m} /$ $\mathrm{m}$.y. just before $2.4 \mathrm{Ma}$, whereas in Hole $633 \mathrm{~A}$ sedimentation rates drop from 24 to $12 \mathrm{~m} / \mathrm{m}$.y. at the Pliocene/Pleistocene boundary (around 1.6 Ma; see also figs. 3 and 4 in Droxler et al., 1988a).

\section{RESULTS}

\section{Presentation of Results}

\section{Fine Aragonite to Total Sediment}

Because of the high and cyclic downcore variations in Holes 714A and 716B (Figs. 2 and 3) of (1) the fine fraction ( $<63 \mu \mathrm{m})$ $(=\%$ Fine Fract (tot sed) $;(2)$ the carbonate content in the fine fraction $(<63 \mu \mathrm{m})\left(=\%\right.$ Fine $\left.\mathrm{CaCO}_{3(\text { Fine Fract })}\right)$; and (3) the aragonite and magnesian calcite proportions in the carbonate content of the fine fraction itself $\left(=\%\right.$ Fine $\left.\mathrm{Arag}_{(\mathrm{Fine}} \mathrm{CaCO}_{3}\right)$ and $\left(=\%\right.$ Fine $\left.\mathrm{MgCalc}_{\text {(Fine CaCO3) }}\right)$, respectively, it is important to recalculate the "raw data" values for aragonite and magnesian calcite content relative to the total sediment by the following simple relation:

$\%$ Fine $\mathrm{Arag}_{(\text {tot sed })}=\left[\%\right.$ Fine $\operatorname{Arag}_{(\text {Fine CaCO3) }} \times \%$ Fine $\mathrm{CaCO}_{3 \text { (Fine Fract) }} \times \%$ Fine Fract (tot sed) $] / 10^{4}$

and

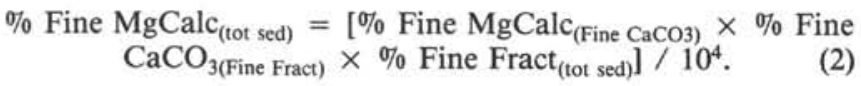

Even though downcore variations of the fine fraction $(<63$ $\mu \mathrm{m})$ and the carbonate content in the fine fraction $(<63 \mu \mathrm{m})$ were not as high in Hole 633A (Fig. 4) as in Holes 714A and $716 \mathrm{~B}$, the values of the raw data of Hole $633 \mathrm{~A}$ were also recalculated relative to the total sediment in order to make an easier comparison between holes in the Maldives and in the Bahamas.

\section{Aragonite and Magnesian Calcite vs. Time}

Since we were able to develop an age/depth model for the three holes based on oxygen isotope, nannofossil and magnetic stratigraphies (see previous section), we present the mineralogical data relative not only to the total sediment, but vs. "Time" rather than "Core Depth". Results are then displayed in two separate sections. The first section presents a comparison of the fine aragonite and magnesian calcite content $(\%)$ to "Total Sediment" with their respective $\delta^{18} \mathrm{O}$ record for the last $1.1 \mathrm{~m} . \mathrm{y}$. in Hole $716 \mathrm{~B}$, the last $0.55 \mathrm{~m} . \mathrm{y}$. in Hole $714 \mathrm{~A}$, and the last 2.0 $\mathrm{m} . \mathrm{y}$. in Hole $633 \mathrm{~A}$. The second results section presents a comparison between the different aragonite records from the three holes and the published carbonate (calcite) preservation records in deep-waters based on the carbonate content of the sediments (Hays et al., 1969; Farrell and Prell, 1987), and on the foraminifer dissolution (calcite) indexes of Peterson and Prell (1985) and Crowley (1985), as well as the pteropod dissolution (aragonite) index of Haddad (1986).

\section{Comparison between Fine Aragonite and $\delta^{18} \mathrm{O}$ Records}

The comparison between $\delta^{18} \mathrm{O}$ records and the fine aragonite cyclic variations downcore is quite important in understanding the origin of the aragonite cycles in periplatform sediments. Low-latitude $\delta^{18} \mathrm{O}$ planktonic records, in addition to their great potential in terms of Pleistocene stratigraphy, can also be used as a proxy sea-level curve (Shackleton and Opdyke, 1973; Shackleton, 1986). If one assumes that the aragonite cycles only reflect the input variations of bank-derived aragonite in relation to flooding and exposure of the shallow banks, then the aragonite cycles will be in phase with the proxy sea-level $\delta^{18} \mathrm{O}$ curve, which in turn will be roughly equivalent to a flooding curve. In this case, light oxygen isotope values during sea-level high stand will correspond to periods of flooded banks, whereas heavy oxygen isotope values during sea-level low stands will correspond to periods of exposed banks.

Figure 8 displays the comparison between $\delta^{18} \mathrm{O}$ and aragonite cycles in Holes 633A and 716B for the past $1.0 \mathrm{~m}$.y. and in Hole $714 \mathrm{~A}$ for the past $0.55 \mathrm{~m}$.y. Figures 9,10 , and 11 are enlarged segments from 0 to $0.4 \mathrm{Ma}$, from 0.3 to $0.7 \mathrm{Ma}$, and from 0.65 to $1.05 \mathrm{Ma}$ of the entire record shown in Figure 8 to aid the visual comparison of both records.

The aragonite and $\delta^{18} \mathrm{O}$ records for the three holes are usually in phase with one another; intervals of high aragonite content parallel intervals characterized by light $\delta^{18} \mathrm{O}$ values, which are thought to correspond with periods of flooded banks, whereas intervals of low aragonite content parallel intervals characterized by heavy $\delta^{18} \mathrm{O}$ values, which are assumed to correspond with periods of bank exposure. In isotope Stages 1-12, the phase relationship between aragonite content and $\delta^{18} \mathrm{O}$ is very 
A. W. DROXLER, G. A. HADDAD, D. A. MUCCIARONE, J. L. CULLEN

A

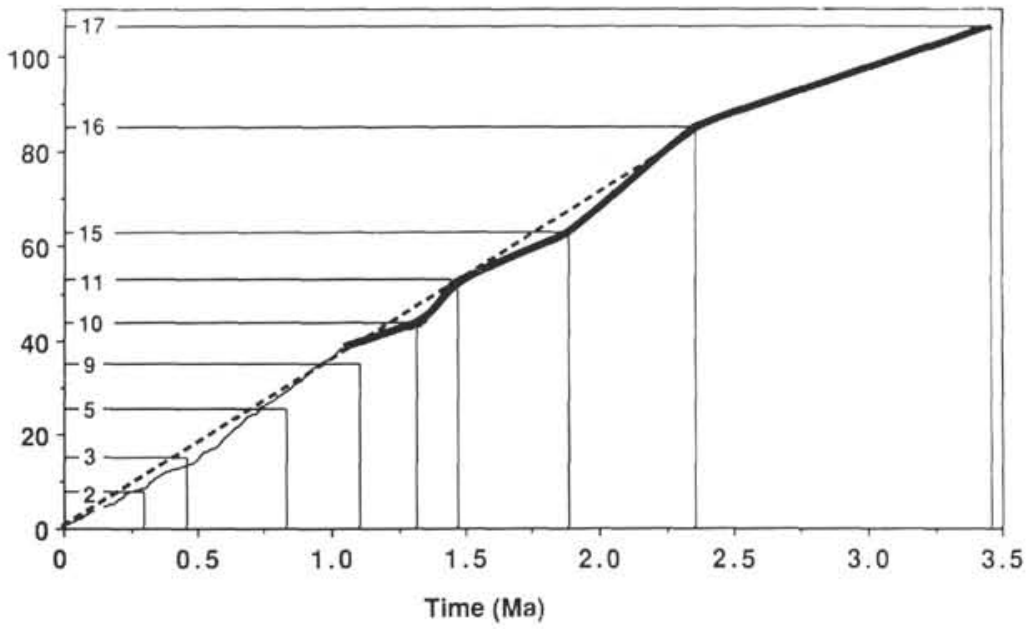

B

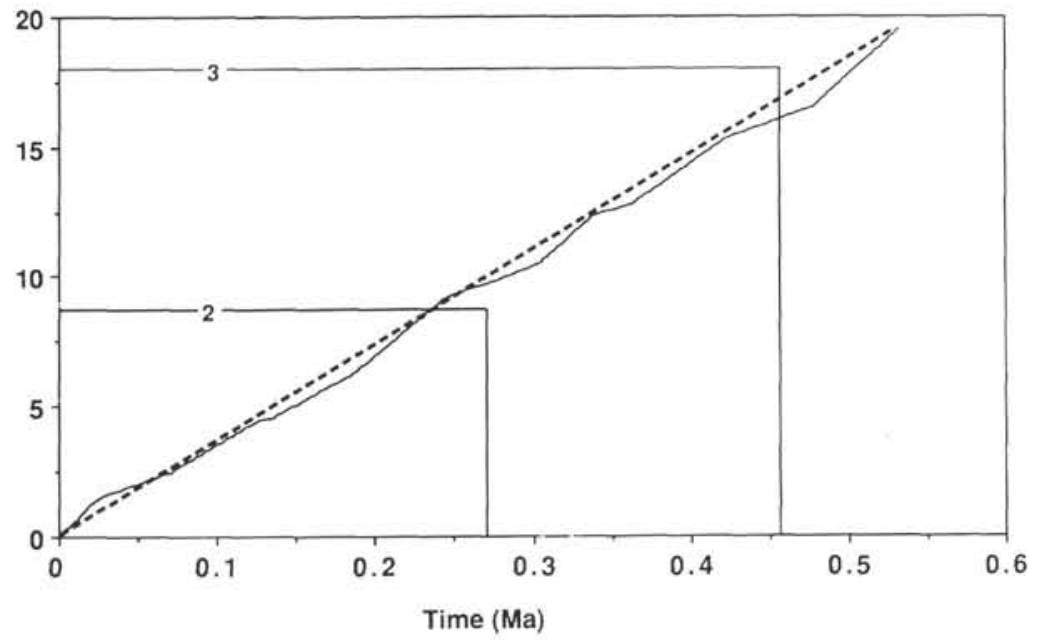

C

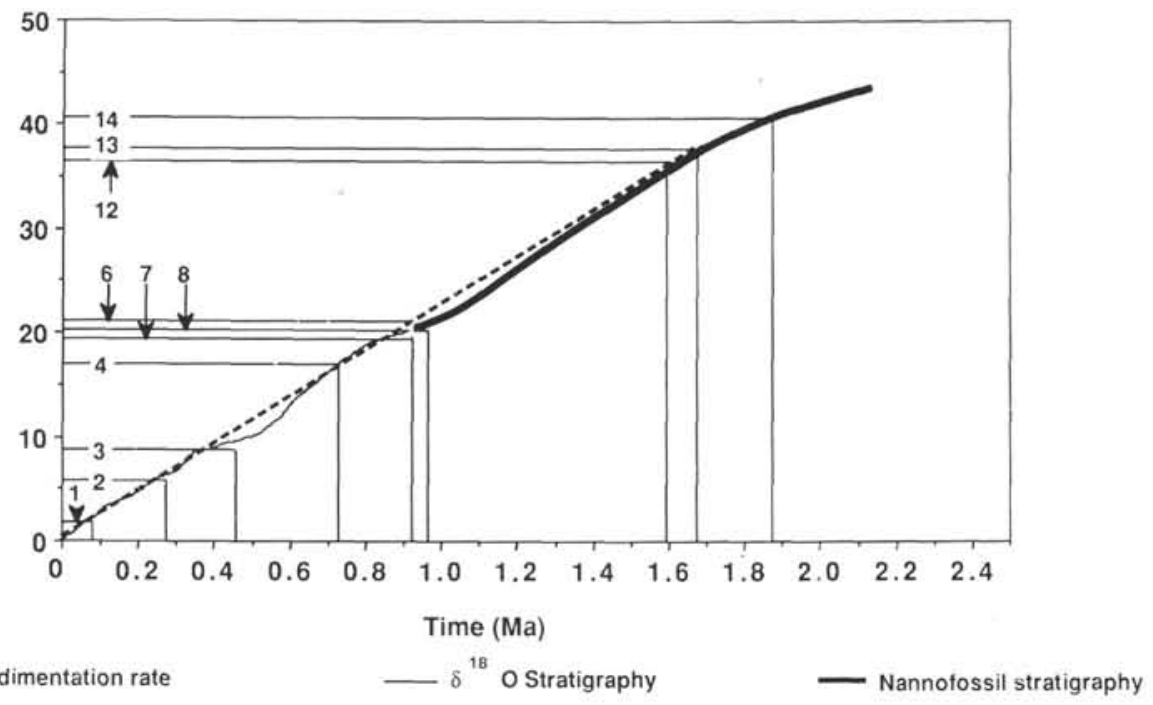

Constant sedimentation rate

Figure 7. Age vs. depth curves for (A) the top $108 \mathrm{~m}$ of Hole 716B, (B) the top $19.5 \mathrm{~m}$ of Hole $714 \mathrm{~A}$, and (C) the top $43.5 \mathrm{~m}$ of Hole $633 \mathrm{~A}$. Age vs. depth models for the last $1.1 \mathrm{~m} . \mathrm{y}$. in Holes $716 \mathrm{~B}$ and $633 \mathrm{~A}$ and for the last $0.55 \mathrm{~m} . \mathrm{y}$. in Hole $714 \mathrm{~A}$ (thin line) are based on oxygen isotope-stratigraphy, assuming constant sedimentation rates for each isotope stage. Available datum levels (plotted as numbers on the diagrams and identified in Table 2) are based on nannofossil stratigraphy (Holes 716B, 714A, and 633A) and magnetic stratigraphy (Hole 633A). Age vs. depth models for times earlier than 1.1 Ma in Holes 716B and 633A are based on established datum levels, nannofossil stratigraphy for Holes 716B and 633A, and magnetic stratigraphy for Hole 633A (thick line). Sedimentation rates are assumed constant between the different datum levels. Notice that the late Pliocene sedimentation rates are lower than the Pleistocene sedimentation rates by a almost a factor of 2. A change of sedimentation rates occurred at 2.5 Ma in Hole 716B and at $1.7 \mathrm{Ma}$ in Hole 633A. 
A

Hole 716B

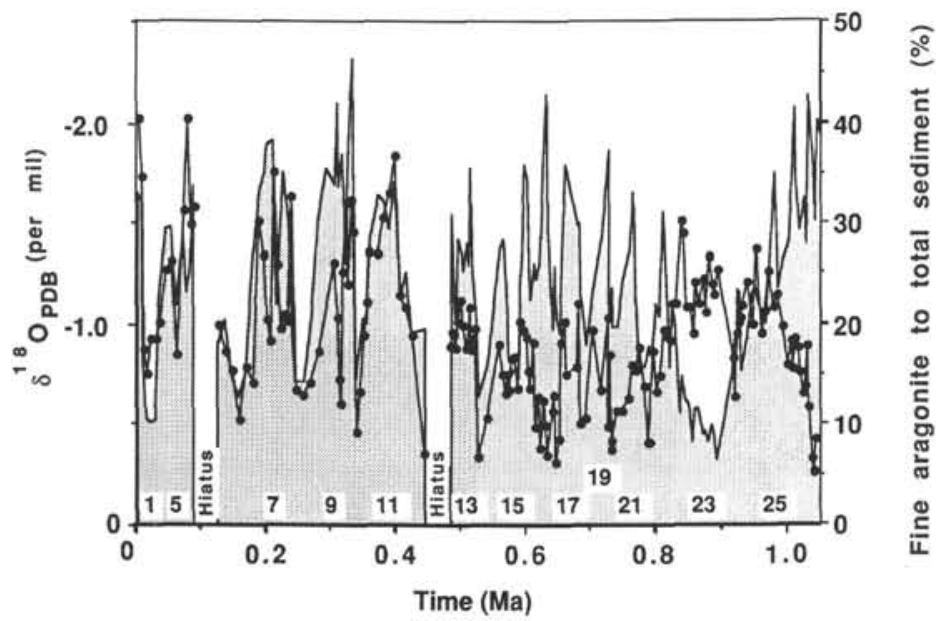

B

Hole 714A

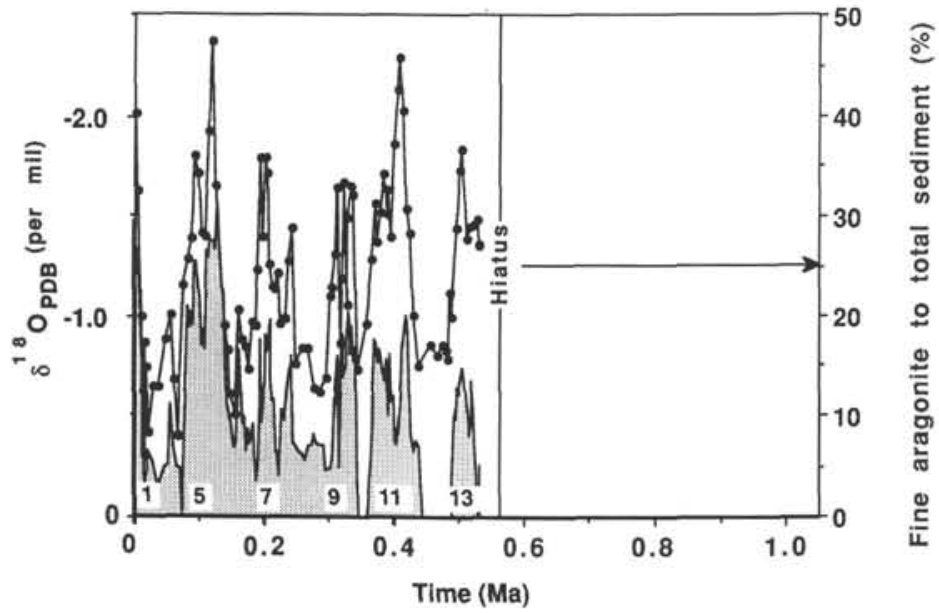

C

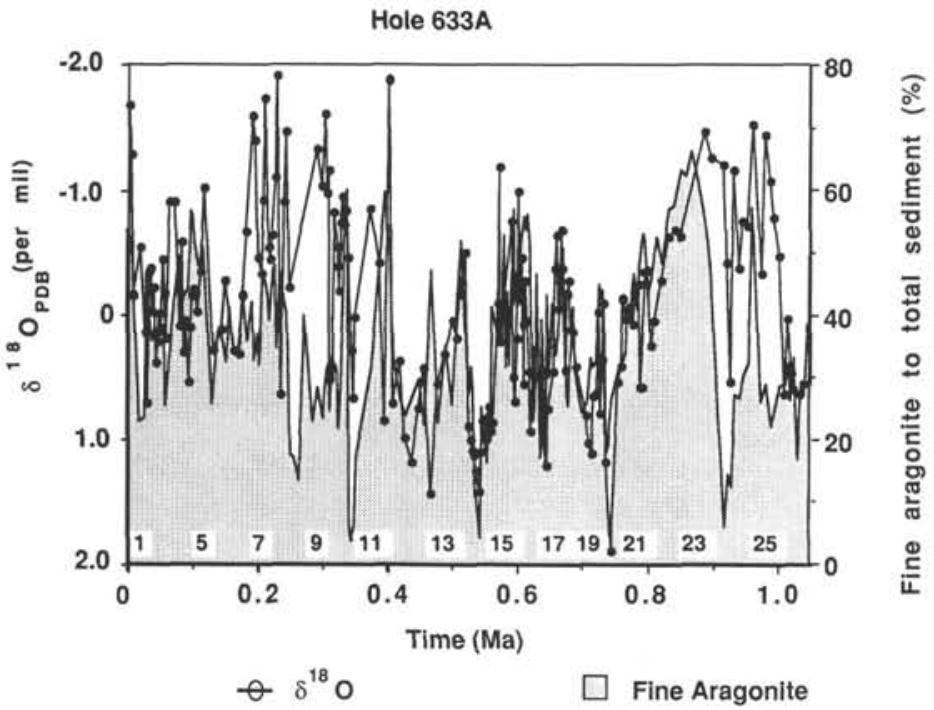

Figure 8. General comparison between planktonic $\delta^{18} \mathrm{O}$ and aragonite (fine aragonite to total sediment) records for the past $1.05 \mathrm{~m} . \mathrm{y}$. in Holes 716B (A), 714A (B), and Hole 633A (C). The $\delta^{18} \mathrm{O}$ and aragonite records are limited to the last $0.55 \mathrm{~m}$.y. in Hole 714A because of a 7.5-Malong hiatus at 19.5 mbsf. Oxygen isotope interglacial stages are identified by odd numbers from 1 to 25 . (Figures 9, 10, and 11 are blow ups of these three records). 
A

Hole 716B
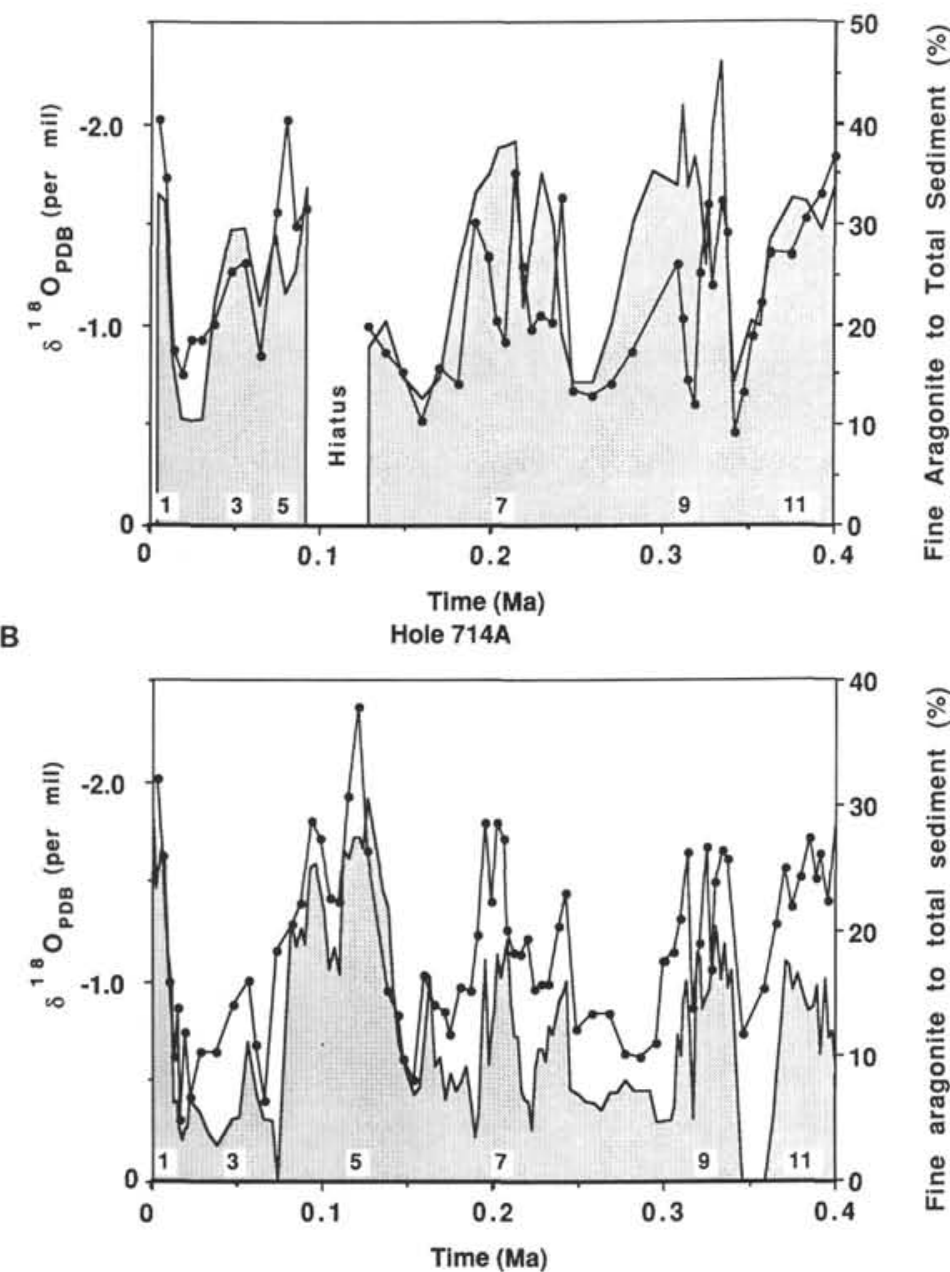

C

Hole 633 A

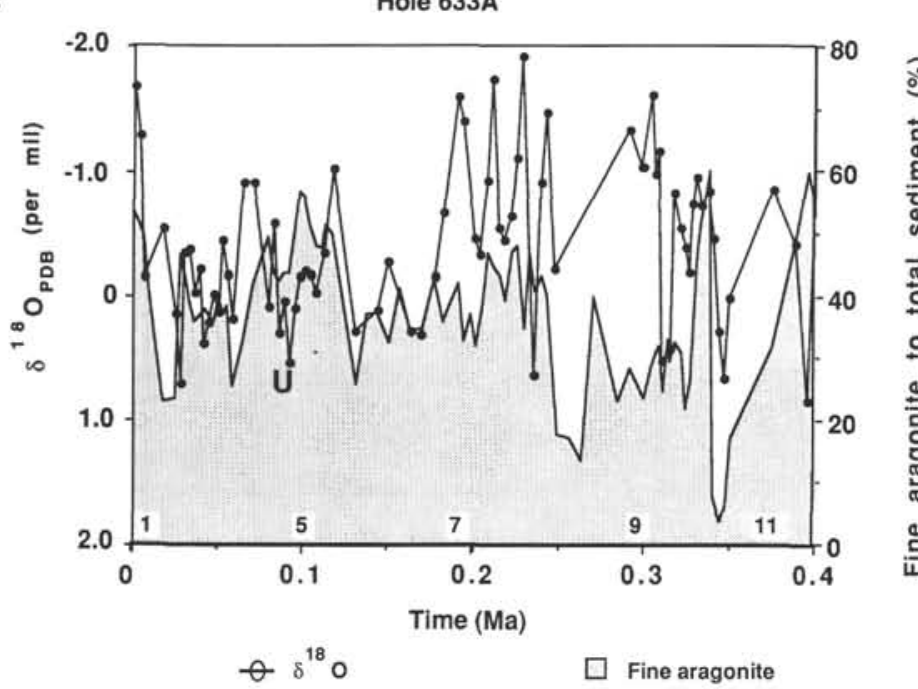

Figure 9. Detailed comparison between planktonic $\delta^{18} \mathrm{O}$ and aragonite records for the last $0.4 \mathrm{~m} . \mathrm{y}$. for Holes 716B (A), 714A (B), and 633A (C). Oxygen isotope interglacial stages are identified by odd numbers from 1 to 11 . Note the in-phase correlation between the $\delta^{18} \mathrm{O}$ and aragonite records. Hole 716B displays the best match between the two records. Note in Hole 714A and 633A the general aragonite decrease with time. Conversely, in Hole 716B, average aragonite values have a tendency to increase with time. In Hole $714 \mathrm{~A}$, the aragonite minima usually occur at the very end of each interglacial stage instead of during each glacial stages, as in Holes $716 \mathrm{~B}$ and $633 \mathrm{~A}$. 
A

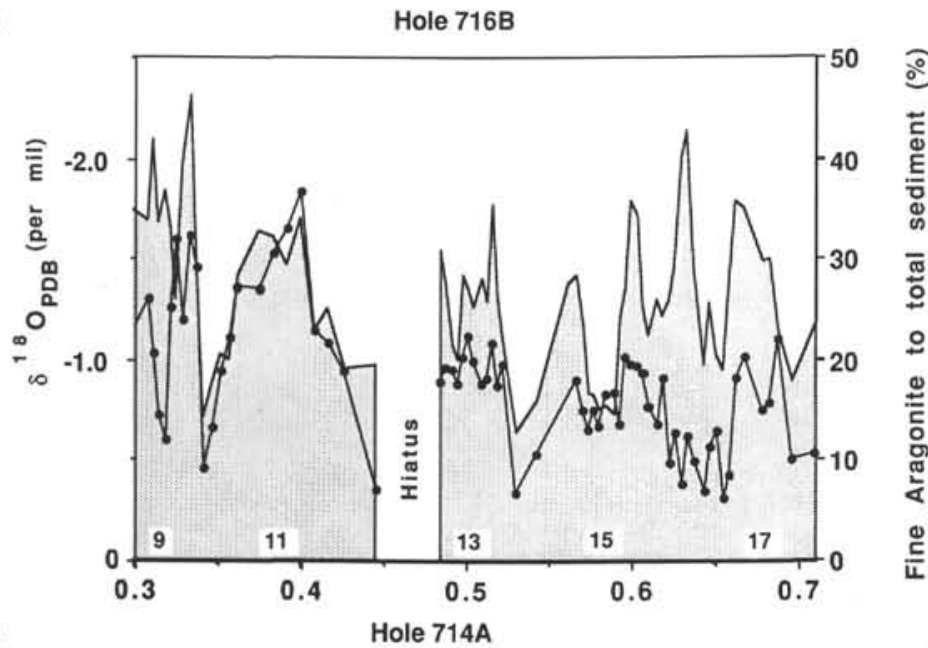

B

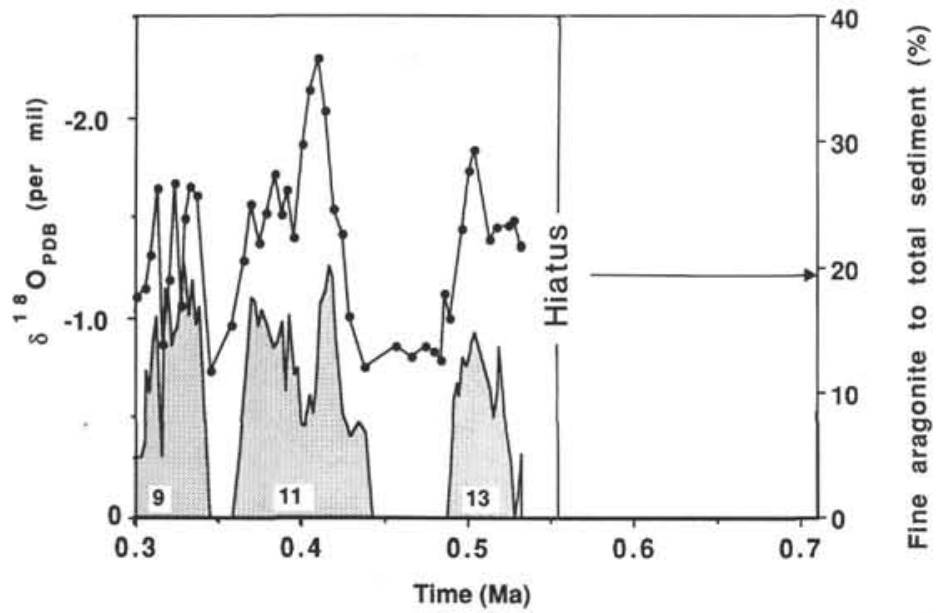

C

Hole 633A

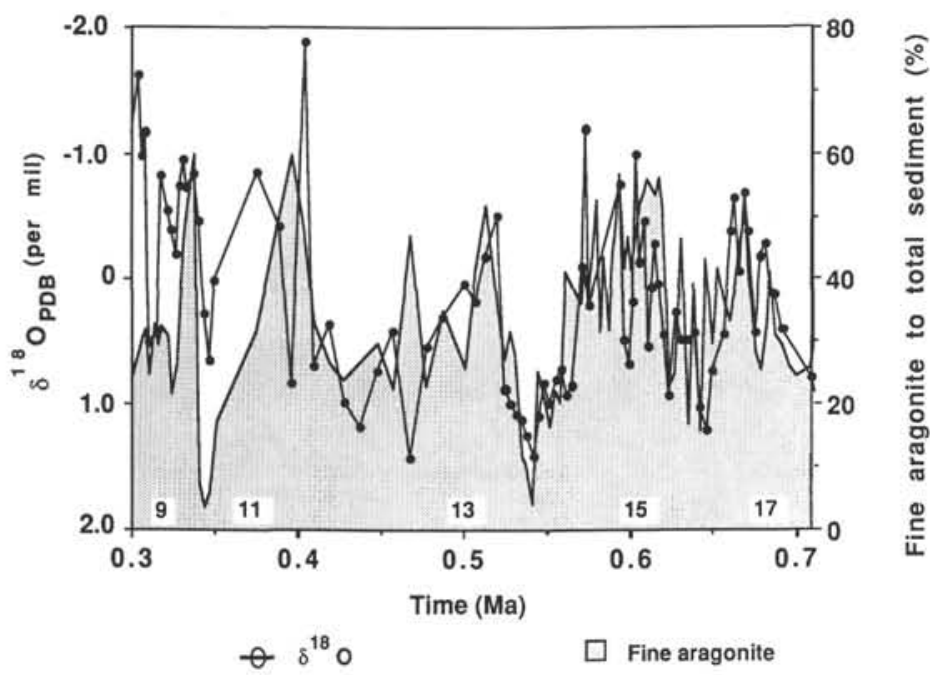

Figure 10. Detailed comparison between planktonic $\delta^{18} \mathrm{O}$ and aragonite records between 0.3 and $0.7 \mathrm{Ma}$ in Holes 716B (A), 714A (B), and 633A (C). Oxygen isotope interglacial stages are identified by odd numbers from 9 to 17 . Note the in-phase correlation between $\delta^{18} \mathrm{O}$ and aragonite records down to Stage 14. In Stages 15 and 16 of Hole $716 \mathrm{~B}, \delta^{18} \mathrm{O}$ and aragonite records are totally out of phase. A major aragonite peak occurs during the second half of glacial Stage 16 and an aragonite minimum is located in the middle of Stage 15. In Hole 633A, an aragonite maximum occurs just at the end of glacial Stage 16. 
A

Hole 716B

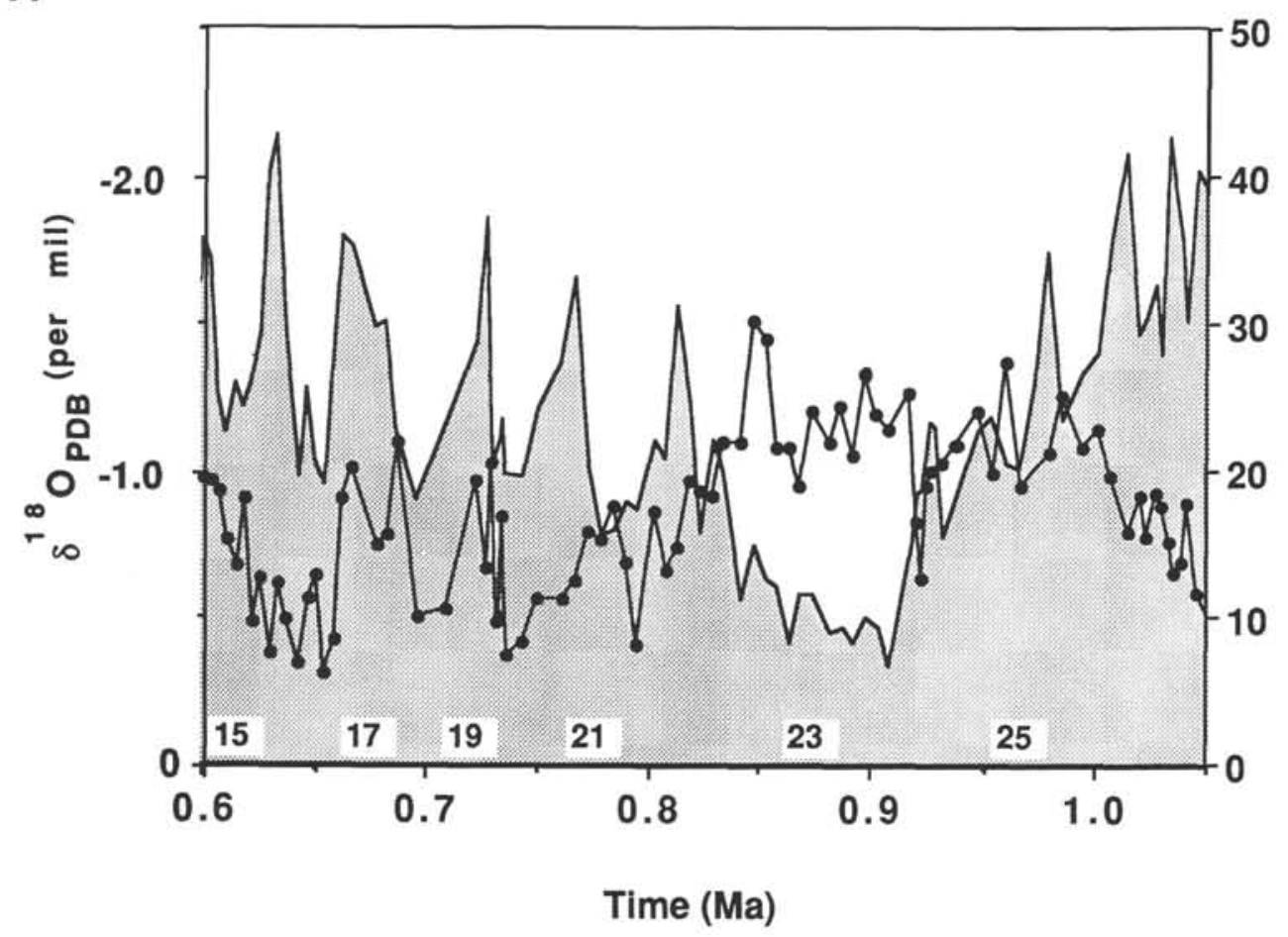

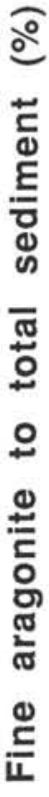

B

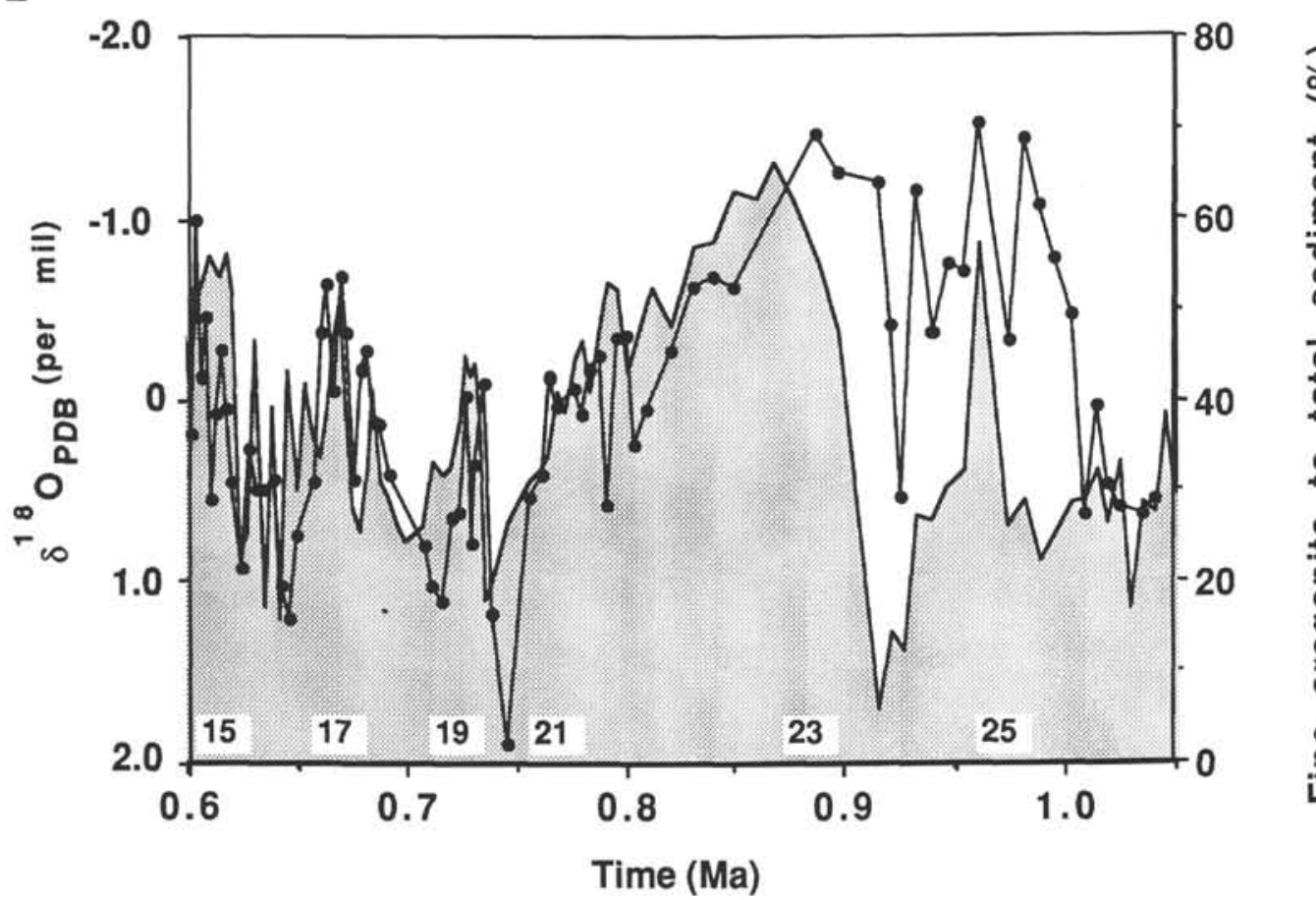

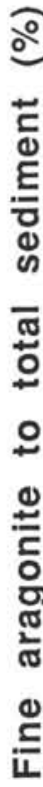

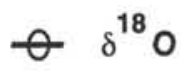

Fine aragonite

Figure 11. Detailed visual comparison between planktonic $\delta^{18} \mathrm{O}$ and aragonite records between 0.6 and $1.1 \mathrm{Ma}$ in Holes 716B (A) and 633A (B). Oxygen isotope interglacial stages are identified by odd numbers from 15 to 25 . Note the out-of-phase relationship between the $\delta^{18} \mathrm{O}$ and aragonite records in Stages 21-26 and particularly during interglacial Stage 23 in both holes. The strongest aragonite minimum of the last 1 m.y. occurred in both holes at the beginning of interglacial Stage $23(0.9 \mathrm{Ma})$, corresponding to light $\delta^{18} \mathrm{O}$ values. Hole $716 \mathrm{~B}$ displays an out-of-phase relationship between $\delta^{18} \mathrm{O}$ and aragonite records during the entire Stage 23, whereas the sharp aragonite increase in Hole $633 \mathrm{~A}$ clearly lags behind the $\delta^{18} \mathrm{O}$ depletion by at least $10 \mathrm{k} . \mathrm{y}$. 
clear in Hole 716B (Figs. 8A, 9A, and 10A). This phase relationship is also observed in Hole 714A (Figs. 8B, 9B, and 10B), with the exceptions of a few subtle lags at the interglacial to glacial boundaries, in which $\delta^{18} \mathrm{O}$ enrichment lags behind the aragonite decrease (i.e., the $\delta^{18} \mathrm{O}$ maximum occurs after the aragonite minimum). The aragonite $/ \delta^{18} \mathrm{O}$ relationship is not as clear for Hole $633 \mathrm{~A}$ as it is in the Maldives holes (Figs. $8 \mathrm{C}, 9 \mathrm{C}$, and $10 \mathrm{C})$. We are quite confident, however, that the few correlative problems encountered in Hole 633A might be more analytical than primary in origin and possibly related to the occurrence of small hiatuses, since good correlations have been observed in the Bahamas at least down to Stages 10 (Droxler et al., 1983) and 12 (Boardman et al., 1986).

Further back in time (Stages 13-26), the "in-phase correlations" between both aragonite and $\delta^{18} \mathrm{O}$ records disappear at certain levels. In Holes $716 \mathrm{~B}$ and $633 \mathrm{~A}$ (Figs. 8A and 8C, 10A and $10 \mathrm{C}$, and $11 \mathrm{~A}$ and $11 \mathrm{~B})$, Stages 15 and 16 and the interval including Stages 21, 23, 25, 26, and 27 are the most obvious cases in which aragonite and $\delta^{18} \mathrm{O}$ records are either out of phase or display major lag times. In Hole $716 \mathrm{~B}$, Stages 15 and 16 are clear examples in which both signals are out of phase (Fig. 10A). For instance, an aragonite peak occurs during the second part of Stage 16, well before the glacial-to-interglacial Stage 16/15 transition. An aragonite minimum also occurs in the middle of interglacial Stage 15 . In Hole 633A, at the same glacial/interglacial stage boundary, aragonite reaches a maximum well before the lightest $\delta^{18} \mathrm{O}$ value of Stage 15 (Fig. 10C). The other interval, during which aragonite and $\delta^{18} \mathrm{O}$ records are not in phase in Holes 633A and 716B, is in the general transition from early to middle Pleistocene Stages $27-21$, but especially during Stage 23 (Figs. 8A, 8C, 11A, and 11B).

In Stage 23 of Hole $716 \mathrm{~B}$, aragonite and $\delta^{18} \mathrm{O}$ are completely out of phase (Fig. 11A). The $\delta^{18} \mathrm{O}$ depletion at the glacial/interglacial Stage $24 / 23$ boundary corresponds to a decrease of aragonite, whereas some of the lightest $\delta^{18} \mathrm{O}$ values at the very beginning of Stage $23(0.9 \mathrm{Ma})$ correspond to the lowest aragonite values $(<10 \%)$ observed during the entire Pleistocene. In addition, the gradual enrichment of $\delta^{18} \mathrm{O}$ values toward the end of Stage 23 surprisingly corresponds to a gradual aragonite increase. Similar out-of-phase relationships can be observed in Stages $22 / 21$ and $26 / 25$. An aragonite minimum occurs at the beginning of Stage 21 defined with light values of $\delta^{18} \mathrm{O}$, an aragonite maximum at the transition between Stages $22 / 21$ and glacial Stage 26 corresponds to a general interval characterized by high aragonite values marked with two aragonite maxima.

The clearest case of aragonite increase lagging behind $\delta^{18} \mathrm{O}$ depletion occurs at the beginning of interglacial Stage 23 in Hole 633A (Fig. 11B). Therefore, the aragonite minimum at the very beginning of Stage $23(0.9 \mathrm{Ma})$, which corresponds to the lowest $\delta^{18} \mathrm{O}$ values, coincides with the aragonite minimum observed in Hole 716B (Figs. 8A, 8C, 11A, and 11B). Stages 22/21 cannot be well distinguished in Hole 633A and trying to observe phase changes or lags between aragonite and $\delta^{18} \mathrm{O}$ would be questionable. Aragonite reaches high values only during the second half of Stage 25. The coincidental occurrence of the most pronounced aragonite minimum during the beginning of Stage 23 in Holes 633A (Bahamas) and 716B (Maldives) cannot be as accidental as one would first think. This period of time (Stages $23 / 22$ ) is also marked in Holes $633 \mathrm{~A}$ and $716 \mathrm{~B}$ by the last short downcore appearance of magnesian calcite (Fig. 12). The penultimate downcore occurrence of magnesian calcite appears synchronously again in Holes $633 \mathrm{~A}$ and $716 \mathrm{~B}$ centered within Stage 15 , another interval in which aragonite and $\delta^{18} \mathrm{O}$ are also out of phase or lag behind one another as in Stage 23 (Figs. 10A and $10 \mathrm{C}$ ). The comparison between the aragonite records from the Bahamas and the Maldives, with the deep carbonate record in

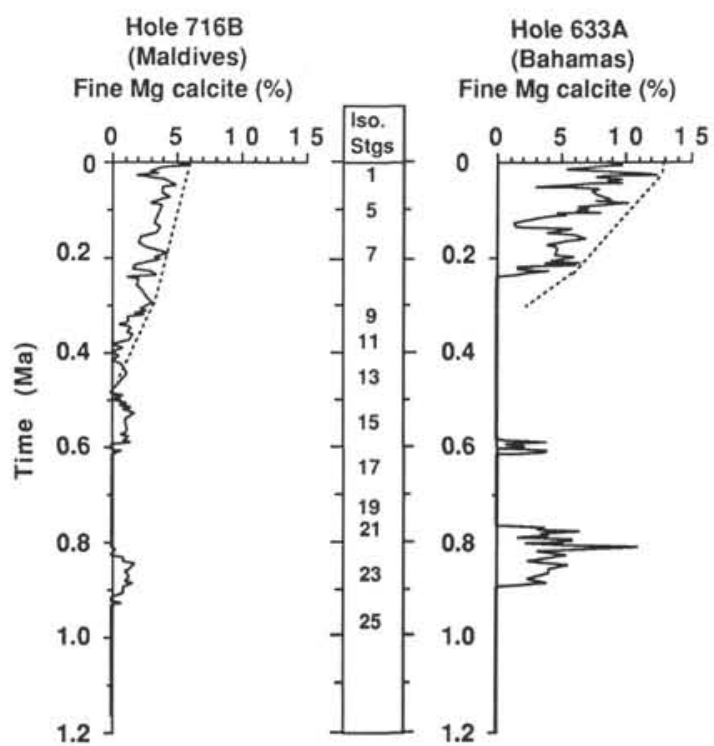

Figure 12. Time variations of magnesian calcite in Hole $716 \mathrm{~B}$ and Hole $714 \mathrm{~A}$ for the past $1.2 \mathrm{~m} . \mathrm{y}$. Note in Hole $716 \mathrm{~B}$ the gradual decrease of magnesian calcite from the surface sediment to $0.4 \mathrm{Ma}$, its reappearance between 0.5 and $0.6 \mathrm{Ma}$ (Stage 15), as well as its final reappearance between 0.8 and $0.9 \mathrm{Ma}$ (Stage 23). An identical pattern is observed in Holes 633A (this figure) and 632A (see Reymer et al., 1988, fig. 3).

the equatorial Pacific Ocean, will help in the interpretation of these peculiar Pleistocene intervals (see "Results" section below).

Below Stage 26, the aragonite record in Hole 716B is completed down to $108 \mathrm{mbsf}$, corresponding to the early Pleistocene and late Pliocene (1.0-3.5 Ma) (Fig. 13). As in the late and middle Pleistocene, aragonite cycles are well developed. Aragonite, ubiquitous in Hole 716B, decreases downcore mostly through one clear step between 1.8 and $2.0 \mathrm{Ma}$, separating two segments characterized by a distinct average aragonite content (Fig. 13). In the first segment (between 1.0 and $1.8 \mathrm{Ma}$ ), aragonite content roughly averages $30 \%$ and reaches the highest values for the entire 3.5-m.y. record. Aragonite content averages $15 \%$ in the second segment (between 2.0 and $3.5 \mathrm{Ma}$ ); this average value is the lowest for the past 3.5 m.y. (Fig. 13). The comparison between $\delta^{18} \mathrm{O}$ and aragonite records for the early Pleistocene and the late Pliocene is not possible since we have yet to produce a $\delta^{18} \mathrm{O}$ curve for Hole 716B below 1.1 Ma.

In Hole 633A from the Bahamas, existing aragonite and $\delta^{18} \mathrm{O}$ records (Droxler et al., 1988b) can be compared during the early Pleistocene and late Pliocene, equivalent to the period between 1.0 and $2.1 \mathrm{Ma}$ (Figs. 14, 15A, 15B, and 15C). Identification of $\delta^{18} \mathrm{O}$ stages during the early Pleistocene and part of the late Pliocene (up to 1.7 or $1.9 \mathrm{Ma}$ ) have been attempted by several authors (Van Donk, 1976; Ruddiman et al., 1986, 1987; and Williams et al., 1988). Each study came up with a different number of stages for the past $1.7 \mathrm{~m}$.y. At the top of the normal polarity Olduvai Subchron (1.67 Ma), Stage 37 was identified in V16-205 by Van Donk (1976), Stage 47 or 49 in V28-239 by Shackleton and Opdyke (1976), Stage 65 in Site 607 by Ruddiman et al. (1987), and finally Stage 59 in the composite record of Williams et al. (1988). In Hole 633A, the top of the Olduvai Subchron (1.67 Ma) corresponds to Stage 49 (Fig. 15B), a similar number of stages to those in V28-239 following Shackleton and Opdyke's stage selection. We use our stage numbers in this study for the early Pleistocene and late Pliocene in Hole 633A only to 

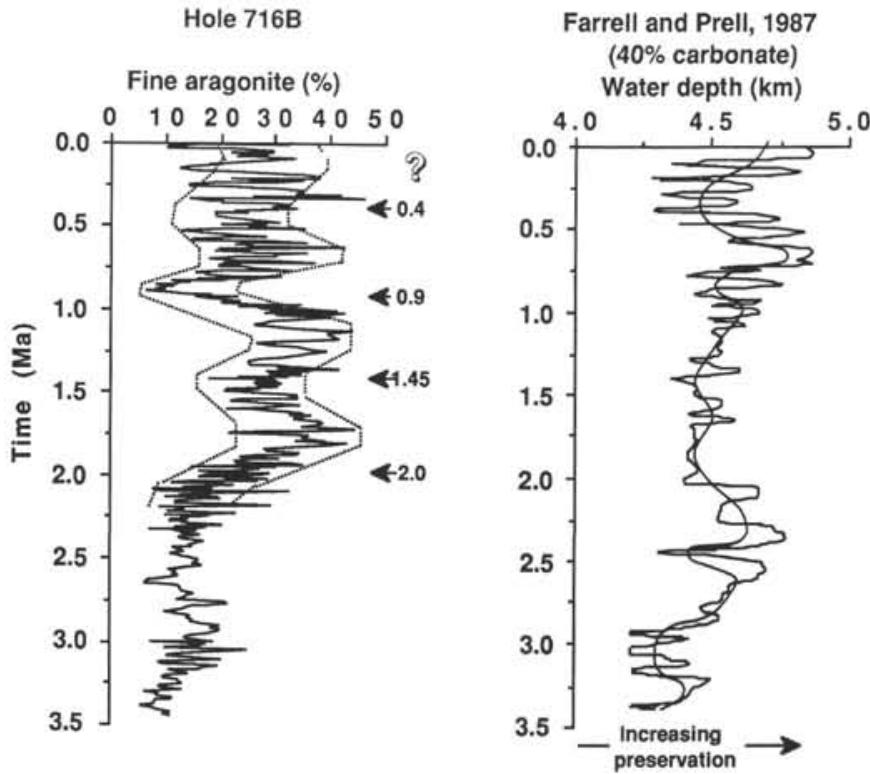

Figure 13. Time variations of aragonite in Hole 716B for the past 3.5 $\mathrm{m} . \mathrm{y}$. Note the aragonite supercycles (roughly with a $0.5-\mathrm{m} . \mathrm{y}$--long period) superposed on the aragonite cycles (visually estimated as 100- and $40-k . y$.-long cycles). Note also the obvious, but unexplained, deviation of the aragonite record from the supercycles during the past $0.4 \mathrm{~m} . \mathrm{y}$. The aragonite record is compared with the bathymetric time variations of the $40 \%$ carbonate contour in the equatorial Pacific Ocean (Farrell and Prell, 1987). Note the rather unimpressive comparison between the timing of the aragonite supercycles and the general carbonate record of Farrell and Prell (1987). This observation contrasts, however, in Figure 19 with the good agreement for the past $2.0 \mathrm{~m}$.y. between the timing of the aragonite supercycles and the carbonate record of Core RC11-209 from the equatorial Pacific Ocean (Hays et al., 1969; Moore et al., 1982).

be able to refer to specific cycles without claiming to introduce here a new stage numbering system.

In Hole 633A, asymmetric aragonite cycles are well defined during the early Pleistocene. Though the aragonite cycles are present during the late Pliocene, they are not as clear, however, as during the Pleistocene and aragonite is not detected during half of the time between 1.65 and $2.1 \mathrm{Ma}$. The early Pleistocene aragonite cycles are not always in phase with $\delta^{18} \mathrm{O}$. The in-phase relationship seems to be the case only for interglacial Stages 33, 39, 41, 45(?), and 47 (Fig. 15A and 15B). Most of the time (Stages 29, 31, 35, 37, and 49), as in interglacial Stage 23, the aragonite minimum occurs at the very beginning of the interglacial stage and the sharp aragonite increase lags roughly $10 \mathrm{k} . \mathrm{y}$. behind the rapid $\delta^{18} \mathrm{O}$ depletion at each glacial-to-interglacial transition. It is only in a few cases (for instance in Stage 27) that aragonite peaks occur during the second part of a glacial stage or at the glacial-to-interglacial transition.

In summary, during the late Pleistocene, aragonite and $\delta^{18} \mathrm{O}$ are usually in phase (i.e., in the Bahamas in several of the piston cores studied [Droxler et al., 1983, 1989; Boardman et al., 1986] and Hole 633A [Droxler et al., 1988b, and this chapter]). They are also in phase in piston cores from the Nicaragua Rise and the Maldives (Droxler et al., 1989) and in Holes 714A and 716B in the Maldives (this chapter), with the exception of piston cores on the Queensland Plateau (southwest Pacific Ocean), where aragonite and $\delta^{18} \mathrm{O}$ are out of phase during the past 100 k.y. (Droxler et al. 1989)]. Further back in time (middle/early Pleistocene and late Pleistocene), however, and during certain intervals, aragonite and $\delta^{18} \mathrm{O}$ records become out of phase or display detectable lags between one another. Intervals during which aragonite and $\delta^{18} \mathrm{O}$ do not appear in phase seem to be correlatable between the Maldives and Bahamas records. As mentioned above, these intervals, during the last $1.1 \mathrm{~m} . \mathrm{y}$., are Stages 15 and 16 and Stages 21-26 (an interval centered on Stage 23), located at the early to middle Pleistocene transition. In addition, magnesian calcite, as a secondary component, reappears unexpectedly during these two particular intervals (Stages 15 and 23). The observation that aragonite cycles are not always in phase with $\delta^{18} \mathrm{O}$ is important to our argument that the aragonite cycles are not only a direct input function resulting from bank flooding and exposure, but that these cycles are also the result of seafloor dissolution of this aragonite input. This is analogous with the carbonate sea floor dissolution of the planktonic calcitic input. We are aware that the $\delta^{18} \mathrm{O}$ record is only a proxy indicator of sea level and that sea-level high stands during certain interglacial stages can be short of flooding a flat top bank or can also overflow a bank and result in drowning it.

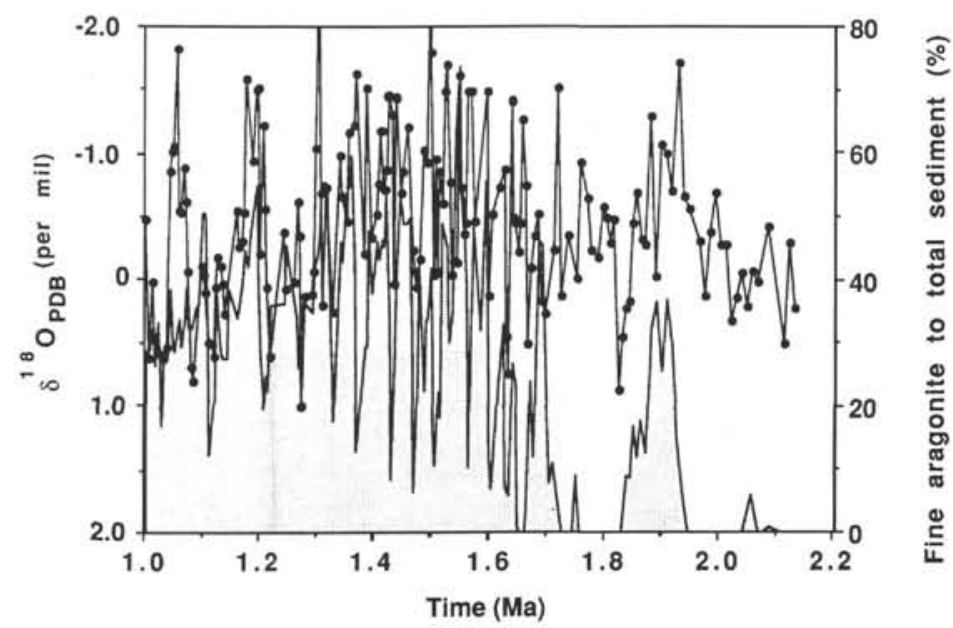

Figure 14. General comparison between planktonic $\delta^{18} \mathrm{O}$ and aragonite records from 1.0 to $2.1 \mathrm{Ma}$ in Hole 633A (see Fig. 15 for more detailed comparisons). 

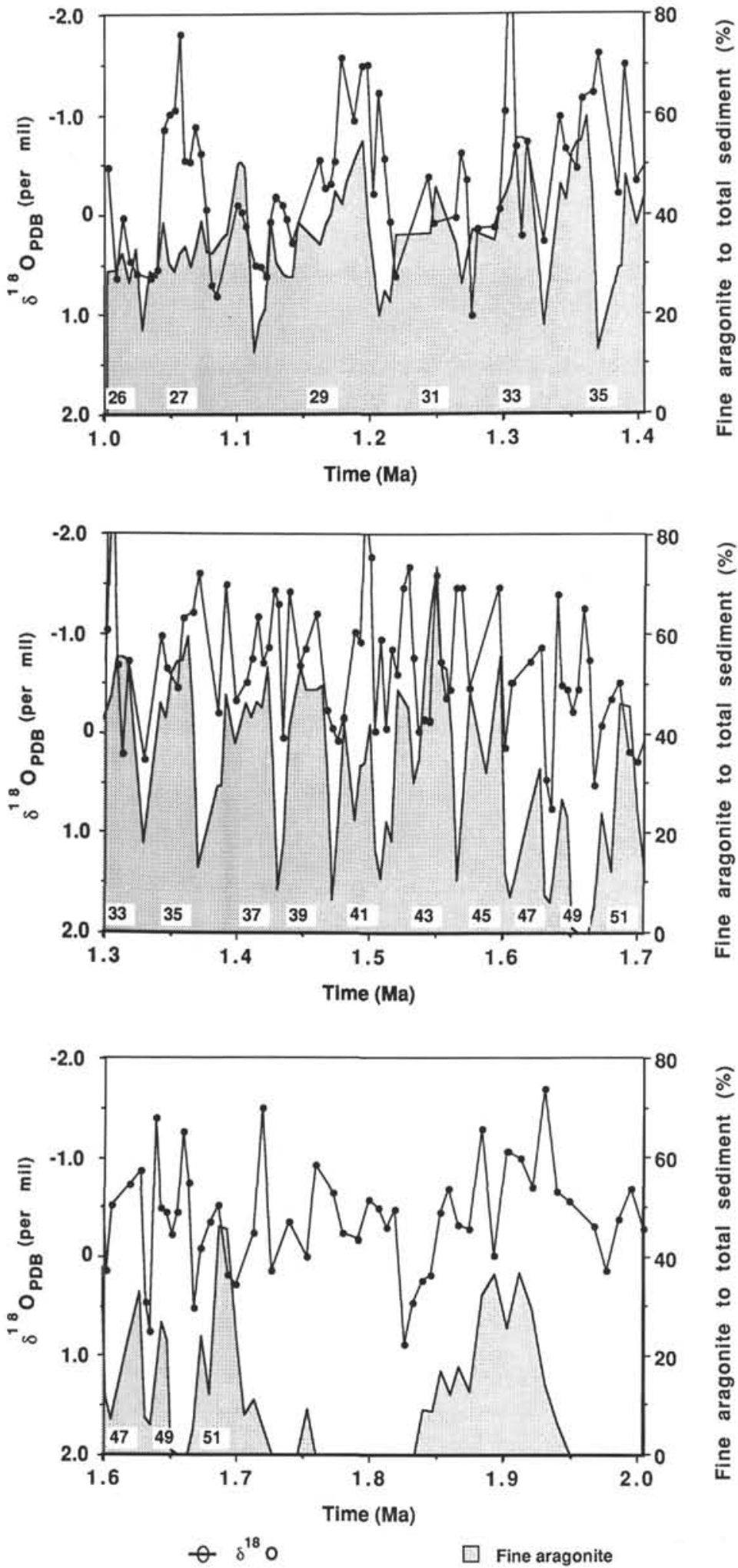

Figure 15. Detailed comparison between planktonic $\delta^{18} \mathrm{O}$ and aragonite records from 1.0 to $2.1 \mathrm{Ma}$ in Hole $633 \mathrm{~A}$. Oxygen isotope interglacial stages are identified by odd numbers from 27 to 51 between 1.0 and $1.7 \mathrm{Ma}$ (top of Olduvai Subchron). Aragonite cycles are either in phase with the $\delta^{18} \mathrm{O}$ cycles or the sharp aragonite increases lag behind the glacial-to-interglacial stage boundaries by $10 \mathrm{k} . \mathrm{y}$. or more, as is clearly the case in Stage 23 (Fig. 11). Note that the irregular low values of aragonite, or intervals characterized by the absence of aragonite, show no clear relationship with the $\delta^{18} \mathrm{O}$ record during the late Pliocene (1.6-2.1 Ma). 


\section{Comparison between Fine Aragonite and Carbonate Preservation Records}

\section{The Last 0.7 m.y. in Holes $714 A$ and $716 B$}

Peterson and Prell (1985) demonstrated in a set of piston cores from the Ninetyeast Ridge (eastern equatorial Indian Ocean) that carbonate preservation, based on a composite dissolution index (CDI), varies periodically through time with dominant 100 - and 40-k.y. cyclicity. In their data set, the carbonate preservation pattern appears to be offset from the $\delta^{18} \mathrm{O}$ glacial/interglacial records. Preservation maxima occur at glacial-to-interglacial transitions, whereas dissolution maxima occur at interglacial to glacial transitions. This particular pattern has been suggested to be global in several studies (e.g., Crowley, 1983, 1985). The data set of Peterson and Prell (1985) also shows evidence of the existence of a longer supercycle, illustrated by generally poor carbonate preservation between 0.3 and $0.6 \mathrm{Ma}$. This supercycle is also well developed in the carbonate records of the equatorial Pacific Ocean, where a poor carbonate interval occurred between 0.2 and 0.5 Ma (Adelseck, 1977; Hays et al., 1969; Moore et al., 1982; Vincent, 1985; Farrell and Prell, 1987, 1989), and in the North Atlantic Ocean, where the 0.20.45 -Ma interval in the mid-Brunhes is known for its poor preservation interval (Crowley, 1985).

Our interpretation of the aragonite cycles, since Droxler et al. (1983), says that these cycles not only record an input function of bank-derived aragonite, produced by alternate flooding and exposure of the nearby banks, but also a preservation of that input tied to climate-induced variable seafloor dissolution. To test our interpretation, we compared (Fig. 16) Peterson and Prell's CDI record with the carbonate preservation record based on the pteropod ratio of Hole $716 \mathrm{~B}$ and the aragonite $0.6-\mathrm{m} . \mathrm{y}$. record of Holes 714A and 716B. Peterson and Prell's age/depth model is based on oxygen isotope stratigraphy, as is our model with ages of stage boundaries defined by Imbrie et al. (1984). The pteropod ratio is defined as (\# whole pteropods)/(\# whole pteropods + \# pteropod fragments). Decreasing values of the pteropod ratio, therefore, correspond to decreasing preservation. The similarities between the aragonite record of Hole 714A (water depth, $2100 \mathrm{mbsl}$ ) and Peterson and Prell's preservation curve are quite impressive. The clear general aragonite decrease with time corresponds to the general decrease of preservation with age noticed by Peterson and Prell as part of the "Brunhes dissolution cycle," with the poorest preservation intervals located between 0.3 and $0.6 \mathrm{Ma}$. Peaks of dissolution in Peterson and Prell's curve correspond to well-defined aragonite minima in Hole 714A, which occur at the end of each interglacial stage, and peaks of preservation correspond to sharp aragonite increases at each glacial-to-interglacial transition (Fig. 16). As expected, the comparison between the aragonite record in Hole 716B (a rather shallow site with a water depth of $540 \mathrm{mbsl}$ ) and the Peterson and Prell's CDI record is not as convincing as it is with the aragonite record in the deepest site (Hole 714A). The aragonite record does not display a systematic decrease with time. Also, although sharp aragonite increases generally coincide with the preservation peaks in Peterson and Prell's CDI Record, the dissolution maxima on the CDI curve correspond to high aragonite values at about 0.3 and $0.4 \mathrm{Ma}$ or to aragonite decreases on the last two interglacial to glacial (7/6 and 5/4) transitions.

In Figure 16, the CDI carbonate preservation curve of Peterson and Prell (1985) is also juxtaposed with the variations with time of the pteropod ratio for Hole 716B during the past 0.6 m.y. The two curves (CDI and pteropod ratio) are again overlain on top of each other in Figure 17. The excellent match between the two curves, mostly between 0 and $0.35 \mathrm{Ma}$, illustrates that fragmentation of pteropod tests amply records the mid-Brunhes dissolution interval in Hole 716B (540 m of water depth). This

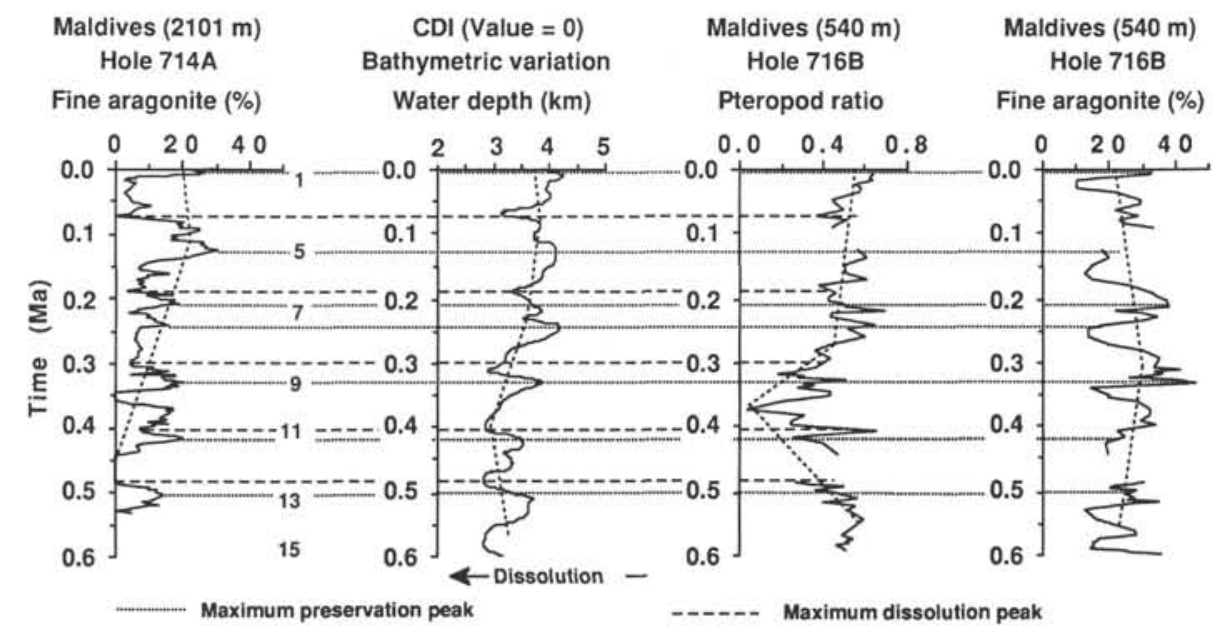

Figure 16. The 0.6-m.y.-long aragonite records for Holes 716B and 714A compared with the carbonate preservation record (CDI) of Peterson and Prell (1985) from the eastern equatorial Indian Ocean, and the Hole 716B pteropod ratio (whole tests/whole tests + fragments). The CDI and pteropod ratio curves are superposed on top of each other in Figure 17 to show the excellent correlation between the two. Note the general agreement between the Hole 714A aragonite record, the CDI from Peterson and Prell (1985), and the Hole 716B pteropod ratio for evidence of a mid-Brunhes poor preservation interval. Also, note the detailed correlations between the CDI record and the Hole 714A aragonite record: maximum preservation peaks correspond to aragonite maxima, and maximum dissolution peaks correspond to aragonite minima, or to an interval during which aragonite was not detected. Correlation between the Hole 714A aragonite record and the Hole 716B pteropod ratio curve shows some similarities, but not as good as with the CDI record. Correlation between the aragonite record and the pteropod ratio curve for the same samples in Hole 716B surprisingly shows no systematic similarities. 


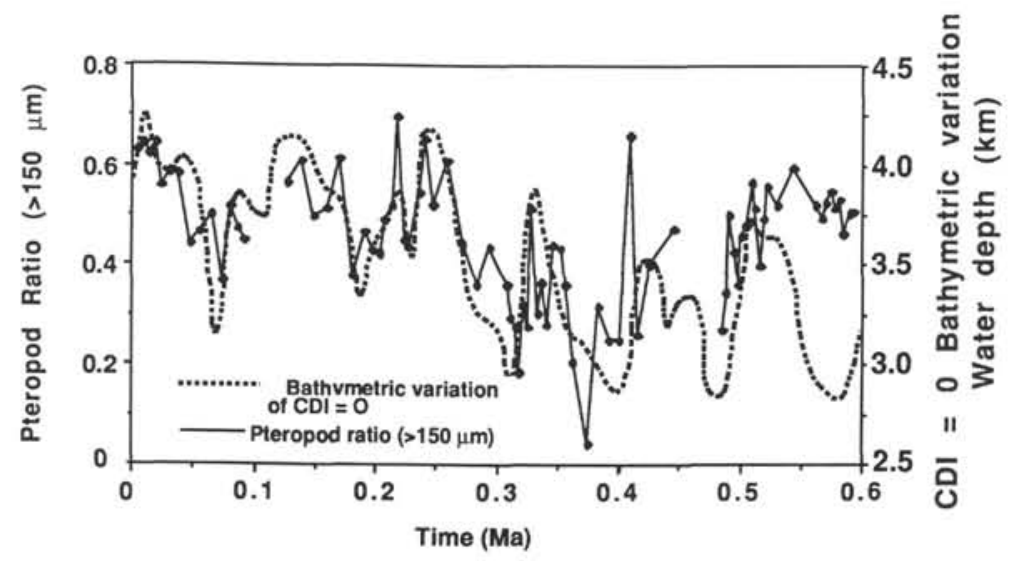

Figure 17. Variations with time of the Hole 716B pteropod ratio are superposed on the CDI bathymetric variations from the eastern equatorial Indian Ocean (Peterson and Prell, 1985) for the past $0.6 \mathrm{~m}$.y. to show the good correlation between the two records. Note the particularly excellent correlation for the past $0.35 \mathrm{~m} . \mathrm{y}$. Also, note the clear mid-Brunhes poor preservation interval between 0.3 and $0.5 \mathrm{Ma}$ in both records.

interval was clearly established in deeper waters (below the calcite lysocline) with the CDI of Peterson and Prell (1985). It is puzzling, however, that during the past $0.6 \mathrm{~m}$.y., well in phase with the $\delta^{18} \mathrm{O}$ record, the aragonite record in Hole 716B (see above) seems to be solely an input signal, even though variations in pteropod-ratio values clearly show the influence of the mid-Brunhes carbonate dissolution. This is an unsolved riddle, especially since the long 3.5-m.y. aragonite record in Hole 716B clearly displays aragonite $0.5-\mathrm{m}$.y. supercycles between 0.5 and 2.0 Ma, which correlate with the well-established carbonate preservation supercycles of the deep equatorial Pacific Ocean (Hays et al., 1969) (see below).

\section{The Last 0.4 m.y. in Hole $633 \mathrm{~A}$}

According to Crowley (1985), the Atlantic pattern of carbonate preservation for the past $0.4 \mathrm{~m}$.y. (i.e., interglacial carbonate preservation and glacial carbonate dissolution) is too simplistic and is not so distinct from the Pacific preservation pattern. Though carbonate dissolution is consistently at a minimum at the very beginning of each interglacial, when the lightest values of $\delta^{18} \mathrm{O}$ indicate minimum ice volume, dissolution intensity appears to increase with increasing ice volume in a nonlinear fashion (Fig. 18). For example, dissolution can be low during some glacial intervals, such as is the case for part of glacial

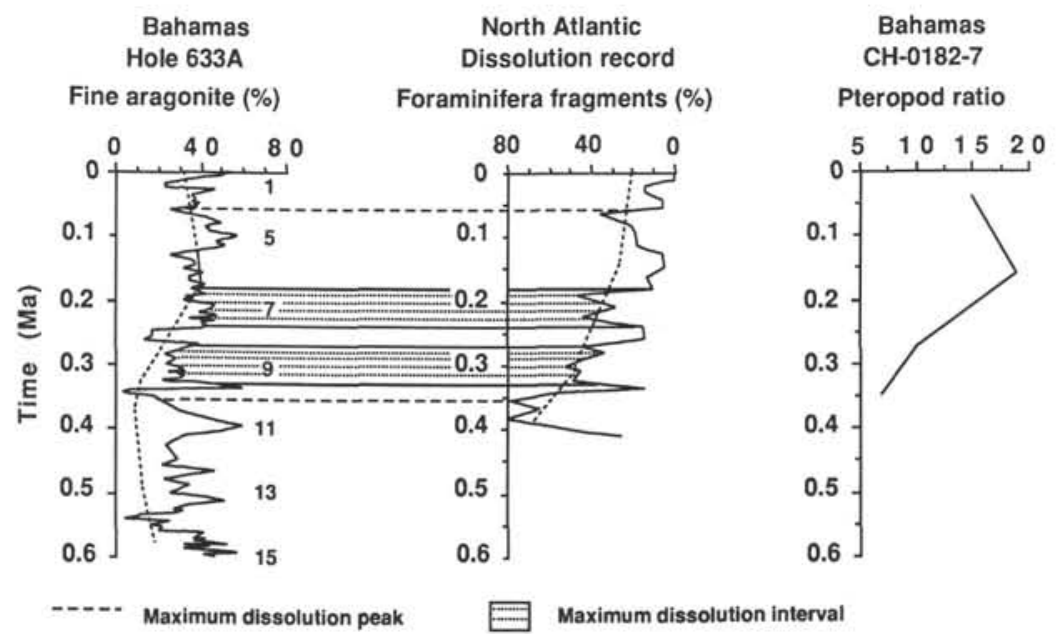

Figure 18. Comparison for the past $0.4 \mathrm{~m}$.y. between the Hole $633 \mathrm{~A}$ aragonite record, the eastern North Atlantic carbonate preservation record based on a foraminifer fragmentation curve (Crowley, 1985), and a carbonate preservation curve based on the pteropod ratio ( $=$ whole pteropods/[whole pteropods + fragments]; Haddad, 1986). Note the aragonite decrease with time in Hole 633A that parallels the decrease with time of carbonate preservation in foraminifer and pteropod curves, and clearly displays the second part of the mid-Brunhes poor preservation interval. Also, note the rather low aragonite values for interglacial Stages 7 and 9 that correspond to two well-defined strong dissolution intervals in the foraminifer carbonate preservation curve. Finally, note the similarities of the carbonate preservation records for the last $0.6 \mathrm{~m}$.y. between the Indian (Figs. 16 and 17) and the North Atlantic oceans (Fig. 18). 
Stages 6 and 8 , which are characterized by two distinct dissolution minima. On the other hand, dissolution in the second part of interglacial Stages 9 and 11 is particularly intense. These dissolution and preservation features, out of phase with the simple glacial/interglacial stage couplet, are part of the increased midBrunhes dissolution interval centered between 0.3 and $0.4 \mathrm{Ma}$. The mid-Brunhes change corresponds to the most recent dissolution maximum of the long-term 0.5 -m.y. carbonate preservation supercycles observed in the Pacific, Atlantic, and Indian oceans, indicating a long-term cyclic excursion of the oceanic carbonate reservoir on a global scale.

The good correlation between Crowley's (1985) 0.4-m.y. fragmentation curve for the northeast Atlantic Ocean (latitude $20^{\circ} \mathrm{N}$ ) and the aragonite $0.4-\mathrm{m} . \mathrm{y}$. aragonite record of Hole $633 \mathrm{~A}$ is a priori unexpected. The general trend of increasing foraminifer fragmentation with time is consistent with the general decrease of average aragonite value for each glacial stage. In addition, high fragmentation intervals within interglacial Stages 7 and 9 correspond to unusually low aragonite values for the interglacial stages. The well-defined, sharp aragonite peak at the very beginning of Stage 9 correlates with the brief carbonate preservation event of Stage 9, and the lowest average aragonite value of glacial Stage 10 corresponds to a maximum in foraminifer fragmentation (Fig. 18).

The mid-Brunhes interval of low carbonate preservation, based on high numbers of foraminifer fragments in the deep Atlantic Ocean (Crowley, 1985) and low aragonite content in the Bahamas, is also recorded by low values of the pteropod ratio in a rather shallow ( $680 \mathrm{~m}$ water depth) periplatform core from the northwest Providence Channel (Haddad, 1986) (Fig. 18). Therefore, the mid-Brunhes trend of poor preservation is clear and common in the periplatform ooze of the Maldives and the Bahamas.

\section{The Last 2.0 m.y. in Holes $633 \mathrm{~A}$ and $716 \mathrm{~B}$ and Core RC11-209 from the Equatorial Pacific Ocean}

Next to the high-frequency (visually estimated as 100 and 40 k.y.) cycles, the 2.0-m.y.-long aragonite record in Hole 716B displays long aragonite cycles in the general envelope of data that are characterized by a periodicity close to $0.5 \mathrm{~m}$.y. when estimated by eye. When one connects aragonite minima in the Pleistocene aragonite curve in Hole 633A from the Bahamas, similar low-frequency $(0.4-0.5 \mathrm{~m} . \mathrm{y}$.) aragonite supercycles appear superimposed on the high-frequency aragonite cycles (Droxler et al., 1988b). Figure 19 shows the 2.0-m.y. aragonite records of Holes 633A and 716B side by side with the carbonate record of Core RC11-209 from the equatorial Pacific Ocean (Hays et al., 1969; Moore et al., 1982; Vincent, 1985). The age/depth model for RC11-209 is based on the published magnetostratigraphy (Hays et al., 1969), assuming constant sedimentation rates within each chron and subchron. Ages of upper and lower chron and subchron boundaries are from Harland et al. (1982). The timing of the aragonite supercycles in Holes 633A and $716 \mathrm{~B}$ matches very well with the timing of the "carbonate preservation supercycles" in Core RC11-209, as well as in several deep carbonate (planktonic calcite) records in the Pacific (Hays et al., 1969; Saito et al., 1975; Adelseck, 1977; Moore et al., 1982; Vincent, 1985; Farrell and Prell, 1987), Indian (Oba, 1969; Peterson and Prell, 1985), and Atlantic oceans (Johnson et al., 1977; Crowley, 1985).

A priori, it is rather unexpected to observe such a correspondence between the two aragonite supercycles in Holes 633A and $716 \mathrm{~B}$, and more particularly with the Pacific long-term carbonate preservation cycles. The timing of the carbonate and aragonite supercycles is common to the three long records. Major intervals characterized by low carbonate values and low aragonite values occur between 0.4 and $0.5 \mathrm{Ma}, 0.8$ and $0.9 \mathrm{Ma}$, and 1.4 and 1.5 Ma. Most of the major carbonate dissolution events of
Hays et al. (1969) and Vincent (1985), such as B3, B7, ..., M1, $\mathrm{M} 3, \ldots \mathrm{M} 11, \mathrm{M} 13, \ldots$, can be correlated in both aragonite supercycles. The major carbonate dissolution event M3 at $0.9 \mathrm{Ma}$, in every long carbonate record, is also the most obvious event in both aragonite records. The M3 event separates the early Pleistocene from the late/middle Pleistocene and seems to have influenced carbonate sedimentation throughout the entire water column worldwide. The aragonite supercycles seem to have vanished during the late Pliocene interval between 1.6 and $2.0 \mathrm{Ma}$ in Hole $633 \mathrm{~A}$, where two distinct aragonite peaks at 1.7 and 1.9 $\mathrm{Ma}$ are separated by intervals during which no aragonite was detected in the carbonate fine fraction. During the same period of time in Hole $716 \mathrm{~B}$, the aragonite supercycles clearly appear and seem to correlate well with the carbonate record of the equatorial Pacific Ocean (Fig. 19).

\section{The Last 3.5 m.y. in Hole $716 B$ and the Equatorial Pacific Ocean Carbonate Preservation Record}

The most detailed Pliocene-Pleistocene carbonate records have been collected from the equatorial Pacific Ocean. Farrell and Prell (1987) displayed them as bathymetric variations in carbonate preservation (expressed as carbonate content in \%) vs. time. The carbonate record in the equatorial Pacific of Farrell and Prell (1987) displays clear carbonate preservation supercycles only during the last $1.0 \mathrm{~m}$.y., with low carbonate values centered on 0.4 and $0.9 \mathrm{Ma}$. Farrell and Prell's carbonate record before 1.0 Ma does not display clear carbonate supercycles, as is the case in the carbonate record of Core RC11-209 between 1.0 and 2.0 Ma (Hays et al., 1969; Moore et al., 1982; Vincent, 1985).

Figure 13 displays side-by-side the $3.5-\mathrm{m} . y$. aragonite record for Hole $716 \mathrm{~B}$ and the $40 \%$ contour of carbonate bathymetric variations for the past 3.5 m.y. (Farrell and Prell, 1987). The aragonite $0.5-\mathrm{m}$.y. supercycles clearly occur during the past 2.0 m.y. Intervals of generally low aragonite are spaced roughly every $0.5 \mathrm{~m} . \mathrm{y}$., at $0.4,0.9,1.45$, and $2.0 \mathrm{Ma}$, and intervals with generally high aragonite at $0.65,1.25$, and $1.75 \mathrm{Ma}$. The aragonite supercycles disappear between 2.0 and $3.5 \mathrm{Ma}$. The aragonite values that average $15 \%$ after $2.0 \mathrm{Ma}$ are the lowest of the entire 3.5-m.y. aragonite record. During the same time interval, however, carbonate preservation in the equatorial Pacific Ocean appears to be better than during the early Pleistocene (Farrell and Prell, 1987). The correspondence between the equatorial Pacific Ocean carbonate preservation record (Farrell and Prell, 1987) and the aragonite record in the Maldives is not as clear as with the carbonate preservation record based on the single Core RC11-209 (Hays et al., 1969; Fig. 19). Further back than 2.0 $\mathrm{Ma}$ (or $70 \mathrm{mbsf}$ ), the primary aragonite record might be significantly altered by burial diagenesis (Malone et al., this volume), which may explain the poor agreement between the aragonite record in the Maldives and the carbonate (calcite) record in the equatorial Pacific Ocean.

\section{DISCUSSION}

\section{Global Occurrence of the Aragonite Supercycles}

The rationale of this paper is based on two separate approaches: (1) comparison between $\delta^{18} \mathrm{O}$ and aragonite records and (2) comparison between aragonite records and the carbonate (calcite) preservation records of the equatorial Pacific, Indian, and Atlantic oceans. The results that emerge from these two approaches point toward the same conclusion. The aragonite cycles in periplatform sediments have recorded not only an input function related to alternate flooding and exposure of the nearby shallow carbonate banks, but are also related to variations in the carbonate chemistry of intermediate-water masses through the dissolution or preservation of bank-derived aragonite at the seafloor. 


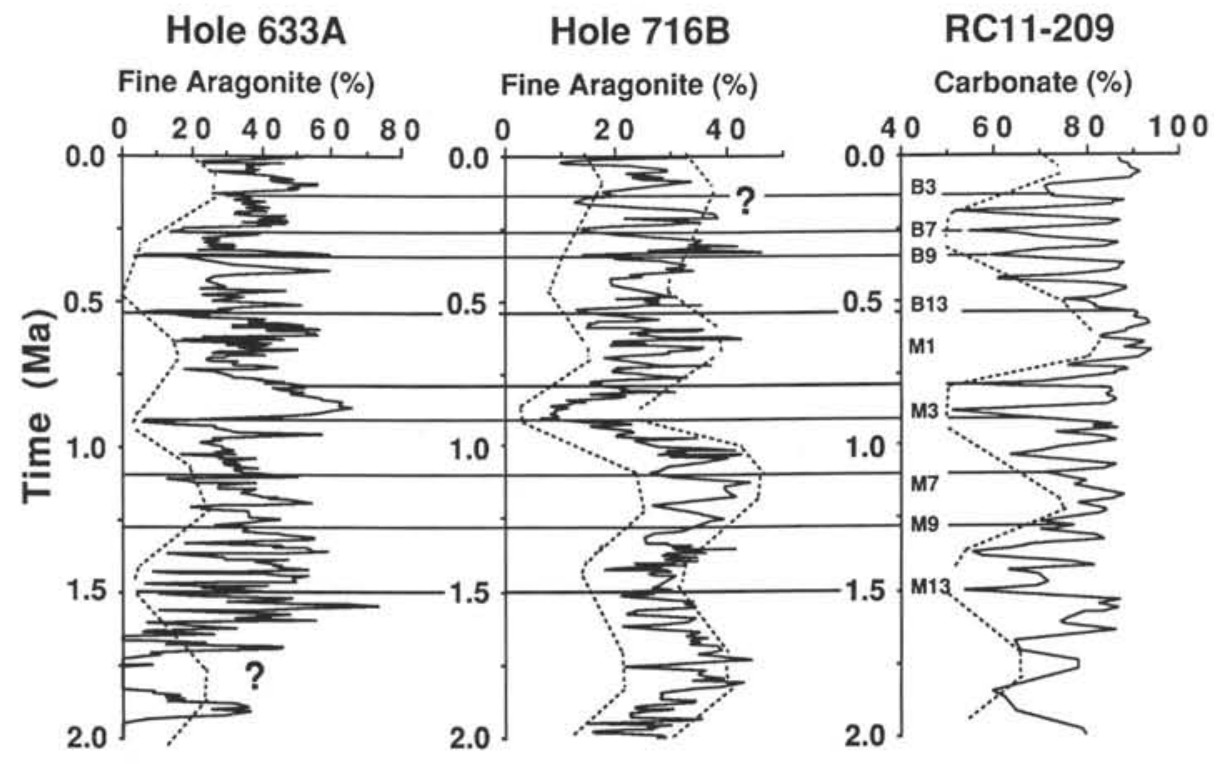

Figure 19. Comparison for the past $2.0 \mathrm{~m} . \mathrm{y}$. between the $0.5-\mathrm{m} . \mathrm{y}$. aragonite supercycles in Holes 633A and 716B, and the 0.5-m.y. carbonate (calcite) supercycles well illustrated in Core RC11-209 (Hays et al., 1969) from the equatorial Pacific Ocean. Timing of the supercycles is almost identical for the three areas. The major dissolution event (M3) of Hays et al. (1969) at $0.9 \mathrm{Ma}$ (early/middle Pleistocene boundary) corresponds to an interval of strong aragonite minima in both Holes 633A and $716 \mathrm{~B}$, and is centered at the beginning of interglacial oxygen isotope Stage 23 (see Fig. 11 for more details). The Hole $633 \mathrm{~A}$ aragonite record deviated from the supercycle trend during the late Pliocene, whereas the Hole 716B aragonite record has been off the supercycle beat in the past 0.3 m.y.

The best evidence for this conclusion is contained in the deep periplatform sites: Hole $633 \mathrm{~A}$ in the Bahamas and Hole $714 \mathrm{~A}$ in the Maldives. The good correlation in Hole 714A between the $0.6-\mathrm{Ma}$ aragonite record and the carbonate preservation record from the Ninetyeast Ridge (Fig. 16), and in Hole 633A between the $0.4-\mathrm{Ma}$ aragonite record and the carbonate preservation record from the tropical eastern North Atlantic Ocean (Fig. 18) show quite clearly that the influence of dissolution increases in each of these aragonite records during the mid-Brunhes. This trend of decreasing aragonite content within the past four or five glacial stages was also observed in three other cores in the Bahamas, where aragonite values are at a minimum during Stage 10 and at a maximum during isotope Stage 6 (Droxler et al., 1988b, fig. 11). In a fourth core, the same trend is strengthened by using pteropod tests and fragments as a dissolution index (Haddad, 1986); stage 10 shows maximum pteropod dissolution, corresponding to the lowest aragonite minimum values, whereas Stage 6 shows minimum dissolution, corresponding to the highest values of the aragonite minimum. This trend corresponds well with the last half of the mid-Brunhes aragonite supercycle (Fig. 18).

Although the trend from late to mid-Brunhes toward more dissolution does not seem to appear during the past 0.4-m.y. aragonite record in shallow Hole 716B (Figs. 13, 16, and 19), it is a priori unexpected that (1) the mid-Brunhes dissolution increase is well illustrated in the pteropod ratio of Hole $716 \mathrm{~B}$ (Figs. 16 and 17), and (2) the 2.0-Ma aragonite record in Hole $716 \mathrm{~B}$ displays distinct $0.5-\mathrm{m} . \mathrm{y}$. aragonite supercycles earlier than the mid-Brunhes (Figs. 13 and 19). The timing of these aragonite supercycles in Hole $716 \mathrm{~B}$ is compatible with the timing of the carbonate preservation supercycles well established in the three major oceans, especially in Core RC11-209 from the equatorial Pacific Ocean (Hays et al., 1969; Moore et al., 1982), as well as with the aragonite supercycles in deep Hole 633A, where the dissolution-increasing trend from the late to the mid-Brun- hes is clear. On the other hand, in Hole 633A, the aragonite supercycles, which are well established during the entire Pleistocene, become less distinct during the late Pliocene (1.6-2.0 Ma) period, during which the aragonite supercycles in Hole 716B are very distinct and regular.

The minima of the aragonite supercycles that correspond to the carbonate dissolution maxima in Hays et al. (1969) occurred approximately every $0.5 \mathrm{~m}$.y.: at $0.40 \mathrm{Ma}$ in Holes 633A, 714A, and $716 \mathrm{~B}$; at 0.90 and $1.45 \mathrm{Ma}$ in Holes 633A and 716B; and at $2.00 \mathrm{Ma}$ in Hole $716 \mathrm{~B}$. The maxima of the aragonite supercycles occurred at $0.15 \mathrm{Ma}$ in Hole $633 \mathrm{~A}$; at 0.65 and $1.20 \mathrm{Ma}$ in Holes 633A and 716B; and at 1.75 Ma in Hole 716B. We concluded that the mid-Brunhes dissolution event, well established as a carbonate low in the pelagic sediments (Farrell and Prell, 1989; Peterson and Prell, 1985; Crowley, 1985), or as an aragonite minimum in the periplatform sediment, is the youngest dissolution interval of the carbonate preservation supercycles. This interval, at least in the aragonite records, is clearly part of a cyclic change and not a steplike phenomenon, in the carbonate (calcite) records, as several authors have mentioned recently (Jansen et al., 1986; Chuey et al., 1987; Pisias and Rea, 1988). In addition, we stress that, because of the occurrence of aragonite supercycles at intermediate water depths in the periplatform environments of the Maldives and the Bahamas regions and the carbonate supercycles in deep waters of the Pacific, Indian, and Atlantic oceans at least during the Brunhes Epoch, we believe that these supercycles have affected the entire water column in low latitudes on a global scale.

Time lags and phase changes between $\delta^{18} \mathrm{O}$ and aragonite records in the Maldives and the Bahamas also provide good evidence that alternate flooding and emergence cannot be the only cause of the aragonite cycles. The synchronous occurrence of these lags and phase changes in aragonite periplatform records of the Maldives and the Bahamas and the relationship of lags and phase changes with the carbonate and aragonite supercycles 
show that they are part of a global phenomenon. In the late and middle Pleistocene, the time during which the aragonite records in Holes $633 \mathrm{~A}$ and $716 \mathrm{~B}$ become out of phase with the $\delta^{18} \mathrm{O}$ record corresponds to two distinct intervals within the carbonate preservation supercycles, as follows:

1. Stages 15 and 16 are recognized to be a time of rather good preservation. Farrell and Prell (1989) recognized a strong preservation event at $0.61-0.65 \mathrm{Ma}$. This is the time in Hole $716 \mathrm{~B}$ at which an aragonite peak $(45 \%)$ occurs. In the $\delta^{18} \mathrm{O}$ record, this peak appears during the second half of glacial Stage 16. The same trend is also observed in Hole 633A, in which an aragonite peak $(58 \%)$ occurs at the very end of glacial Stage 16. In Holes $633 \mathrm{~A}$ and $716 \mathrm{~B}$, the aragonite and $\delta^{18} \mathrm{O}$ records are in phase during Stages 17, 18, 19, and 20. This is a period of generally good preservation within the carbonate supercycles (i.e., see Farrell and Prell, 1989).

2. The second interval during which aragonite and $\delta^{18} \mathrm{O}$ records become either totally or partially out of phase in Holes $633 \mathrm{~A}$ and $716 \mathrm{~B}$ is during Stages $21-26$. This interval includes the very end of the Matuyama Chron and the Jaramillo Subchron and is centered on Stage 23. It is synchronous with a major carbonate dissolution event at $0.9 \mathrm{Ma}$, the M3 event of Hays et al. (1969) that corresponds to the major excursion in the carbonate preservation curve of Farrell and Prell (1987). In Hole $716 \mathrm{~B}$, Stage 23 is marked by one of the most extreme aragonite minima even though, based on the $\delta^{18} \mathrm{O}$ record, it corresponds to an interglacial stage. In Hole 633A, this M3 dissolution event is not as clearly defined as in Hole 716B, but it still corresponds to the most-developed Pleistocene mismatch between aragonite and $\delta^{18} \mathrm{O}$. The "M3/0.9 Ma" aragonite minimum occurs at the beginning of interglacial Stage 23. The sudden aragonite increase, from $<10 \%$ to $>65 \%$, lags behind the $\delta^{18} \mathrm{O}$ depletion, defining the Stage 24/23 glacial-to-interglacial transition by more than $10 \mathrm{k} . \mathrm{y}$. The occurrence of magnesian calcite during Stage 23 in Holes 633A and 716B is also quite significant. Magnesian calcite could have precipitated as cement as a result of the partial seafloor dissolution of aragonite. This interpretation remains hypothetical and will need to be tested by detailed petrographic and geochemical analyses.

\section{Implications}

Several implications are tied to the established occurrence of the global aragonite supercycles in periplatform sediments and their correlation with the carbonate (calcite) preservation supercycles in open-ocean pelagic sediments. The aragonite cycles and supercycles can no longer be treated simply as the response of the nearby shallow carbonate banks to sea-level fluctuations.

We think that modifications in the aragonite input, through partial or full dissolution at the sea floor of bank-derived aragonite, have recorded cyclic variations in carbonate chemistry of the overlying waters, though this interpretation seems better established in deep periplatform sites (Holes 633A and 714A) than in shallow sites (i.e., Hole 716B). Therefore, the aragonite cycles and supercycles become unique tools to understand how the carbonate chemistry of the water column at intermediatewater depths and low latitudes responded to Quaternary climatic changes. Carbonate chemistry variations at intermediate water-depths are practically unknown, since calcitic planktonic material is too stable to record subtle variations in the carbonate chemistry above the calcite lysocline. Based on the carbonate (calcite) records in the equatorial Pacific Ocean, Farrell and Prell (1989) were able to show that the top of the calcite lysocline (thought to correspond to the calcite saturation level in the water column) deepened by a minimum of 400 to $800 \mathrm{~m}$ during the last nine glacial stages corresponding to the past $0.8 \mathrm{~m} . \mathrm{y}$. Farrell and Prell related this deepening to an increase of the deep-water carbonate ion concentration, resulting in a more carbonate saturated-water mass. Climate-induced calcite lysocline excursions of similar magnitude have been reported by other authors. Berger (1977) suggested as much as a 1000-m lysocline excursion in the Pacific Ocean. In the Atlantic, Gardner (1975) reported a 200-700 m change, Berger (1968) and Crowley (1983) suggested that an excursion of $300 \mathrm{~m}$ may have occurred, and Balsam (1983) saw evidence for a change on the order of $1000-2000 \mathrm{~m}$ in the glacial-to-interglacial lysocline depth. Climate-induced shallowing and deepening of the water-column carbonate saturation levels over the orbital frequencies $\left(10^{\text {th }}\right.$ $100^{\text {th }} \mathrm{k} . \mathrm{y}$.), as positive or negative feedbacks, are directly related to the cycling of deep-sea carbonate sediment, as well as oceanic and atmospheric carbon reservoirs.

Shoaling of the aragonite lysocline (aragonite saturation level) in intermediate-water masses, in parallel with the excursion of the calcite lysocline in deeper waters, is not too difficult to conceive. The records of the carbonate chemistry variations of intermediate water masses in periplatform ooze, though more subtle than in deep-water masses because of their quicker turnover rates and their more direct connection to the atmosphere are essential to our quest for a better understanding of the role of the atmosphere, the ocean, and carbonate sediments in the carbon-cycling processes.

Aragonite supercycles are well developed during the late Pliocene-Pleistocene, mainly between 0.3 and $2.0 \mathrm{Ma}$ in the shallow Maldives site, Hole $716 \mathrm{~B}$. This would imply that the aragonite saturation level would have reached water depths shallow enough to be located within the oxygen minimum. Such a shallow aragonite saturation level is not unreasonable, given the shallow (300-400 m) aragonite saturation level in the central $\mathrm{Pa}-$ cific today at latitude $18^{\circ} \mathrm{N}$ (Berner, 1977). Another example from the Nicaragua Rise (Caribbean Sea) also shows waters within the oxygen minimum, between 700 and $1000 \mathrm{~m}$, just at or below the aragonite saturation level today. Deeper waters become saturated again between 1000 and $1900 \mathrm{~m}$ and finally become undersaturated at or below $1900 \mathrm{~m}$ (Droxler et al., 1988c). Aragonite records from the Maldives and the Bahamas, partially interpreted as carbonate preservation records, would therefore illustrate some major excursions through time of the aragonite saturation level, indicating that the carbonate chemistry of the entire water column, and not only of the deep-ocean basins, has varied within the beat of the climate-induced fluctuations.

Similarities between the different aragonite and carbonate records during some time intervals point out that the entire water column has responded as a whole to certain climatic modulators, whereas differences between the aragonite records themselves, or between the intermediate aragonite and the deep carbonate (calcite) records may be related to basin-to-basin or intermediate-to-deep-water carbonate fractions. A possible example of basin-to-basin fractionation is illustrated in the aragonite records during the late Pliocene (1.6-2.0 Ma). In the Maldives (Hole 716B) during that period of time, aragonite supercycles are well defined and can be correlated well with the carbonate (calcite) preservation record. On the other hand, aragonite supercycles in the Bahamas (Hole 633A) during the same period of time were not observed, perhaps because aragonite was not even detected during half of this time. This discrepancy, between the Bahamas and the Maldives, is possibly related to the onset of the major glaciations in the North Atlantic Ocean at 2.4 Ma (i.e., Shackleton et al., 1984). This event could have had a 1.0-Ma-long "local" influence on the formation of corrosive intermediate water masses in the North Atlantic Ocean.

The other mismatch between the two aragonite supercycles occurs during the past $0.3 \mathrm{~m}$.y. In the shallow Maldives site (Hole 716B), the Brunhes aragonite supercycle, clearly in sediment older than $0.3 \mathrm{Ma}$, displays a regular aragonite decrease 
since $0.3 \mathrm{Ma}$, instead of a general aragonite increase as expected during the period of time following the last mid-Brunhes carbonate preservation minimum (Figs. 13, 16, and 19). This mismatch is rather unexpected and not understood at this point because the mid-Brunhes dissolution interval based on the pteropod ratio is so clear in Hole 716B (Figs. 16 and 17). On the contrary, the last aragonite supercycle during the Brunhes Chron is well developed in the deep sites, in the Bahamas (Hole 633A) and in the Maldives (Hole 714A), following the trend of the deep carbonate (calcite) preservation record in the deep equatorial Pacific and Indian oceans, as well as in the deep tropical North Atlantic Ocean. Therefore, the paleoceanographic implications in relation to the establishment of the global aragonite supercycles in periplatform sediments become multifold.

Finally, mineralogical variations, observed downcore cannot be simply explained any more only by shallow burial diagenesis. First, the primary input of bank-derived metastable aragonite and magnesian calcite has changed through time. Then, chemical reactions occurring at the seafloor through interaction between surface sediments and overlying waters have also modified this primary input by removing, at specific time intervals, the primary input of bank-derived material. For instance, the general decrease of aragonite with time in the past $0.4 \mathrm{~m}$.y. in Holes $633 \mathrm{~A}$ and $714 \mathrm{~A}$, linked with the youngest mid-Brunhes interval of poor preservation and part of the global carbonate preservation supercycles, could easily be misinterpreted as early burial diagenesis (Mullins et al., 1985; Dix and Mullins, 1988). Good examples are (1) the reoccurrence of magnesian calcite in the Maldives and the Bahamas during Stages 15 and 23 and (2) the aragonite extreme minima during Stage 23 in both areas, correlated to the deep-water calcite dissolution event M3 of Hays et al. (1969). In Droxler et al. (1988a), we also demonstrated that major reversals of aragonite content occur within a longer time interval in Hole 633A. In this hole, aragonite is only partially detected during the late Pliocene (1.7-2.1 Ma), whereas during the early Pliocene (4.0-4.5 Ma) values of aragonite content $(70 \%)$ are equal to or higher than the aragonite values observed during the interglacial late Pleistocene stages. The establishment of the carbonate (aragonite) preservation supercycles in periplatform sediments shows the importance of chemical processes that occur at the seafloor during discrete climatic intervals.

\section{CONCLUSIONS}

Long-term (roughly 0.5 m.y.) aragonite supercycles have been recorded in the periplatform environments of the Maldives and the Bahamas at least for the past $2.0 \mathrm{~m}$.y. The aragonite supercycles generally correlate quite well not only between these two regions, but also with the carbonate (calcite) preservation records from the deep equatorial Pacific, Indian, and tropical North Atlantic oceans. By analogy, we interpret the aragonite supercycles in the periplatform environments as preservation cycles at intermediate-water depths.

Aragonite and planktonic $\delta^{18} \mathrm{O}$ records are not always in phase, as is usually the case during the late Pleistocene. These mismatches between aragonite and $\delta^{18} \mathrm{O}$ are good evidence that the aragonite cycles in periplatform sediments can no longer be explained solely by variations of aragonite input from the nearby shallow carbonate banks in response to their alternate flooding and exposure through cyclic sea-level fluctuations. Two major mismatches between the aragonite and $\delta^{18} \mathrm{O}$ records synchronously occur in the Maldives and Bahamas regions during the past $1.1 \mathrm{~m}$.y. During these two distinct time intervals (Stages 15 and 16 and Stages $21-27$ ), aragonite and $\delta^{18} \mathrm{O}$ are either totally out of phase or the aragonite record lags behind the $\delta^{18} \mathrm{O}$ by several tens of thousands of years. The major mismatch event, which is located at the beginning of Stage $23(0.9 \mathrm{Ma})$ and cor- responds to the early to middle Pleistocene boundary, is illustrated by one of the most extreme aragonite minima during the entire Pleistocene in the Maldives and the Bahamas. This 0.9m.y. event corresponds to the M3 major dissolution event in the carbonate preservation records of the equatorial Pacific Ocean.

The mid-Brunhes interval of poor carbonate preservation, well established in carbonate dissolution curves of the equatorial Pacific, Indian, and tropical Atlantic oceans, is clearly defined by aragonite lows in deep (1500-2000 m) periplatform sites of the Maldives and the Bahamas, as well as by increases in pteropod fragmentation in the shallow sites (500-700 m).

Paleoceanographic and paleoclimatologic implications linked to the occurrence of the aragonite cycles and supercycles in periplatform sediments at intermediate water depths are multifold. Their occurrence shows that the carbonate chemistry of the entire water column was influenced by long-term $(0.5 \mathrm{~m} . \mathrm{y}$.) climate-induced and cyclic variations during the past $2.0 \mathrm{~m}$.y. It also shows that the aragonite saturation levels were perhaps as shallow as $500 \mathrm{~m}$ at different time intervals in the equatorial Indian and tropical North Atlantic oceans, as is the case today in the central equatorial Pacific Ocean. Major changes of the water column carbonate chemistry, recorded in periplatform aragonite cycles and supercycles, are part of the climate-induced carbon cycling among the different atmospheric, oceanic, and sedimentary reservoirs.

The establishment of aragonite preservation supercycles in periplatform ooze shows the importance of the chemical processes that occur at the seafloor between surface sediments and the overlying waters, and that these processes are modulated by late Pliocene/Pleistocene climatic changes. Downcore decreases of aragonite and magnesian calcite, therefore, are not necessarily related to early burial diagenesis occurring within the top 10 $20 \mathrm{~m}$ of sediment. The mid-Brunhes climate-induced poor carbonate preservation interval (around $0.4 \mathrm{Ma}$ ) is a clear example, during which aragonite values reach a minimum and then increase further down the core. This trend is even more clear in the Bahamas where the aragonite, which disappears during the late Pliocene, reaches values that are as high during the early Pliocene as during the late Pleistocene.

\section{ACKNOWLEDGMENTS}

This research was supported by several grants from USSACJOI to A. W. Droxler (Leg 115), J. L. Cullen (Leg 115), and A. W. Droxler and W. Schlager (Leg 101), as well as partially by NSF Grant No. OCE-8796273 to A. W. Droxler. We thank the personnel of the ODP Core Depository of Texas A\&M in College Station, particularly C. Mato, for helping during the core sampling, and S. Walker, L. Baker, S. Staples, and D. Greene at Rice University for help during sample processing and analyses. We are particularly grateful to R. B. Dunbar, who made his Stable Isotope Laboratory at Rice University available to us for oxygen isotope analyses. J. W. Farrell and an anonymous person thoroughly reviewed the first manuscript.

\section{REFERENCES}

Adelseck, C. G., Jr., 1977. Recent and late Pleistocene sediments from the eastern equatorial Pacific Ocean: sedimentation and dissolution [Ph.D. dissert.]. Univ. California, San Diego.

Arrhenius, G., 1952. Sediment cores from the east Pacific. Rep. Swed. Deep-Sea Exped., 5:1-227.

Austin, J. A., Schlager, W., et al., 1986. Proc. ODP, Init. Repts., 101: College Station, TX (Ocean Drilling Program).

Backman, J., Duncan, R. A., et al., 1988. Proc. ODP, Init. Repts., 115: College Station, TX (Ocean Drilling Program).

Balsam, W. B., 1983. Carbonate dissolution on the Muir Seamount (western North Atlantic): interglacial/glacial changes. J. Sediment. Petrol., 53:719-731.

Berger, W. H., 1968. Planktonic foraminifera selective solution and paleoclimatic interpretation. Deep-Sea Res., 15:31-43. 
1973. Deep-sea carbonates: Pleistocene dissolution cycles. J. Foraminiferal Res., 3:187-195.

1977. Deep-sea carbonate and deglaciation preservation spike in pteropods and foraminifera. Nature, 269:301-304.

1978. Deep-sea carbonate: pteropod distribution and the aragonite compensation depth. Deep-Sea Res., 25:447-452.

Berner, R. A., 1977. Sedimentation and dissolution of pteropods in the ocean. In Andersen, N. R., and Malahoff, A. (Eds.), The Fate of Fossil Fuel $\mathrm{CO}_{2}$ in the Oceans: New York (Plenum Press), 243-260. 1981. Pelagic sedimentation of aragonite: its geochemical significance. Science, 211:940-942.

Berner, R. A., Berner, E. K., and Keir, R. S., 1976. Aragonite dissolution on the Bermuda Pedestal, its depth and geochemical significances. Earth Planet. Sci. Lett., 30: 169-178.

Birch, G. F., 1979. In-progress reports of the year 1978. Cape Town, Univ. Dept. Geol., Mar. Geol. Program, Tech. Rep., 11:122-126.

Boardman, M. R. 1978. Holocene deposition in northwest Providence Channel, Bahamas: a geochemical approach [Ph.D. dissert.]. Univ. North Carolina, Chapel Hill.

Boardman, M. R., and Neumann, A. C., 1984. Sources of periplatform carbonate: northwest Providence Channel, Bahamas. J. Sediment. Petrol., 54:1110-1112.

1985. Sources of periplatform carbonates: northwest Providence Channel, Bahamas-reply. J. Sediment. Petrol., 55:929-931. 1986. Reply on "Bank-top responses to Quaternary fluctuations in sea level recorded in periplatform sediments." Geology, 14: 1040-1041.

Boardman, M. R., Neumann, A. C., Baker, P. A., Dulin, L. A., Kenter, R. J., Hunter, G. E., and Kiefer, K. B., 1986. Bank-top responses to Quaternary fluctuations in sea level recorded in periplatform sediments. Geology, 14:28-31.

Burns, S. J., 1983. The sedimentary process of a deep-water carbonate slope: southern Little Bahama Bank, Bahamas [M.S. thesis]. Univ. North Carolina, Chapel Hill.

Burns, S. J., and Neumann, A. C., 1987. Pelagic sedimentation on an inactive gullied slope, northwest Providence Channel, Bahamas. Mar. Geol., 77:277-286.

Chen, C., 1964. Pteropod ooze from Bermuda Pedestal. Science, 144: 60-62.

1968. Pleistocene pteropods in pelagic sediments. Nature, 219:1145-1149.

Chuey, J. M., Rea, D. K, and Pisias, N. G., 1987. Late Pleistocene paleoclimatology of central equatorial Pacific, a quantitative record of eolian and carbonate deposition. Quat. Res., 28:323-339.

Crowley, T. J., 1983. Calcium carbonate preservation patterns in the central North Atlantic during the last 150,000 years. Mar. Geol., 51: $1-41$.

1985. Late Quaternary carbonate changes in the North Atlantic and Atlantic/Pacific comparisons. In Sundquist, E. T., and Broecker, W. S. (Eds.), The Carbon Cycle and Atmospheric $\mathrm{CO}_{2}$ : Natural Variations Archean to Present. Am. Geophys. Union Monogr., $32: 271-284$.

Diester-Haas, L., 1985. Late Quaternary sedimentation on the eastern Walvis Ridge, southeast Atlantic (HPC 532 and four piston cores). Mar. Geol., 65:145-189.

Dix, G. R., and Mullins, H. T., 1988. A regional perspective of shallowburial diagenesis of deep water periplatform carbonates from the Northern Bahamas. In Austin, J. A., Jr., Schlager, W., et al., Proc. ODP, Sci. Results, 101: Washington (Ocean Drilling Program), 279302.

Droxler, A. W., 1984. Late Quaternary glacial cycles in the Bahamian Deep Basins and in the adjacent ocean [Ph.D. dissert.]. Univ. Miami, Coral Gables, FL.

1985. Last deglaciation in the Bahamas: a dissolution record from variations of aragonite content? In Sundquist, E. T., and Broecker, W. S. (Eds.), The Carbon Cycle and Atmospheric $\mathrm{CO}_{2}$ : Natural Variations Archean to Present. Am. Geophys. Union Monogr., 32:195-207.

1986. Comment on "Bank-top responses to Quaternary fluctuations in sea level recorded in periplatform sediments. Geology, $14: 1039-40$.

Droxler, A. W., Bruce, C. H., Sager, W. W., and Watkins, D. H., 1988b. Pliocene-Pleistocene variations in aragonite content and planktonic oxygen-isotope record in Bahamian periplatform ooze, Hole 633A.
In Austin, J. A., Jr., Schlager, W., et al., Proc. ODP, Sci. Results, 101: College Station, TX (Ocean Drilling Program), 221-244.

Droxler, A. W., Glaser, K. S., Morse, J. W., and Baker, P. A., 1988c. Good agreement between carbonate mineralogical depth variations of surficial periplatform ooze and carbonate saturation levels of overlying intermediate water. New data from the Nicaragua Rise. Eos, 69:1048. (Abstract)

Droxler, A. W., Haddad, G. A., and Mucciarone, D. A., 1989. Influence of the "Brunhes Carbonate Cycle" on the periplatform 1-m.y.long aragonite record in the Bahamas and the Maldives. 3rd Int. Conf. Paleoceanogr., Terra Abstr., 1:16-17.

Droxler, A. W., Morse, J. W., and Kornicker, W. A., 1988a. Controls on carbonate mineral accumulation in Bahamian basins and adjacent Atlantic Ocean sediments. J. Sediment. Petrol., 58:120-130.

Droxler, A. W., and Schlager, W., 1985a. Glacial/interglacial sedimentation rates and turbidite frequency in the Bahamas. Geology, 13: 799-802.

1985b. Sources of periplatform carbonates: northwest Providence Channel, Bahamas-discussion. J. Sediment. Petrol., 55:928929.

Droxler, A. W., Schlager, W., and Whallon, C. C., 1983. Quaternary aragonite cycles and oxygen-isotope records in Bahamian carbonate ooze. Geology, 11:235-239.

Farrell, J. W., and Prell, W. L.,1987. Climate forcing of calcium carbonate sedimentation: a $4.0 \mathrm{~m}$.y. record from the central equatorial Pacific Ocean. Eos, 68:333.

1989. Climatic change and $\mathrm{CaCO}_{3}$ preservation: an 800,000 year bathymetric reconstruction from the central equatorial Pacific Ocean. Paleoceanography, 4:447-466.

Gardner, J. V., 1975. Late Pleistocene carbonate dissolution cycles in the eastern equatorial Atlantic. In Sliter, W. V., Bé, A.W.H., and Berger, W. H. (Eds.), Dissolution of Deep-Sea Carbonates. Spec. Publ., Cushman Found. Foraminiferal Res., 13:129-141.

Haddad, G. A., 1986. A study of carbonate dissolution, stable isotope chemistry, and minor element composition of pteropods and forams deposited in the Northwest Providence Channel, Bahamas, during the past 500,000 years [M.S. thesis]. Duke Univ., Durham, NC.

Hanna, J. C., and Moore, C. H., 1979. Quaternary temporal framework of reef to basin sedimentation, Grand Cayman, B.W.I. Geol. Soc. Am., Abstr. Programs, 11:438.

Harland, W. B., Cox, A. V., Llewellyn, P. G., Pickton, C.A.G., Smith, A. G., and Walters, R., 1982. A Geologic Time Scale: Cambridge (Cambridge Univ. Press).

Hays, J. D., Saito, T., Opdyke, N. D., and Burckle, L. H., 1969. Pliocene-Pleistocene sediments of the equatorial Pacific: their paleomagnetic biostratigraphic and climatic record. Geol. Soc. Am. Bull., 80:1481-1514.

Herman, Y., 1971. Vertical and horizontal distribution of pteropods in Quaternary sequences. In Funnel, B. M., and Riedel, W. R. (Eds.), The Micropaleontology of the Oceans: Cambridge (Cambridge Univ. Press), 463-486.

Hine, A. C., Wilber, R. J., and Neumann, C., 1981. Carbonate sand bodies along contrasting shallow bank margins facing open seaways in northern Bahamas. AAPG Bull., 65:261-290.

Imbrie, J., Hays, J. D., Martinson, D. G., McIntyre, A., Mix, A. C., Mortley, J. J., Pisias, N. G., Prell, W. S., and Shackleton, N. J., 1984. The orbital theory of Pleistocene climate: support from a revised chronology of the marine $\delta^{18} \mathrm{O}$ record. In Berger, A., Imbrie, J., Hays, J., Kukla, G., and Saltzman, B. (Eds.), Milankovitch and Climate (Pt. 1): Hingham, MA (D. Reidel), 69-305.

Jansen, J.H.F., Kuijpers, A., and Troelstra, S. R., 1986. A mid-Brunhes climatic event: long-term changes in global atmospheric and ocean circulation. Science, 232:619-622.

Johnson, D. A., Ledbetter, M., and Burckle, L. H., 1977. Vema Channel paleoceanography: Pleistocene dissolution cycles and episodic bottom water flow, Mar. Geol., 23:1-33.

Kier, J. S., and Pilkey, O. H., 1971. The influence of sea level changes on sediment carbonate mineralogy, Tongue of the Ocean, Bahamas. Mar. Geol., 11:189-200.

Lynts, G. W., Judd, J. B., and Stehman, C. F., 1973. Late Pleistocene history of Tongue of the Ocean, Bahama. Geol. Soc. Am. Bull., 84: 2605-2684.

Milliman, J. D., 1974. Marine Carbonates: Berlin-Heidelberg-New York (Springer-Verlag). 
Moore, T. C., Jr., Pisias, N. G., and Dunn, D. A., 1982. Carbonate time series of the Quaternary and late Miocene sediments in the Pacific Ocean: a spectral comparison. Mar. Geol., 46:217-233.

Müller, G., and Gastner, M., 1971. The "Karbonat-Bombe," a simple device for the determination of the carbonate content in sediments, soils and other materials. N. Jahrb. Mineral. Monatsh., 10:466-469.

Mullins, H. T., 1983. Comment on "Eustatic control of turbidites and winnowed turbidites." Geology, 11:57-58.

Mullins, H. T., Neumann, A. C., Wilber, R. J., Hine, A. C., and Chinsburg, S. J., 1980. Carbonate sediment drifts in northern Straits of Florida. AAPG Bull., 64:1701-1717

Mullins, H. T., Sherwood, W. W., Gardulski, A. F., Hinchey, E. J., Masters, P. M., and Siegel, D. I., 1985. Shallow subsurface diagenesis of Pleistocene periplatform ooze: northern Bahamas. Sedimentology, 32:473-494.

Oba, T., 1969. Biostratigraphy and isotopic paleotemperatures of some deep-sea cores from the Indian Ocean. Tohoku Univ. Sci. Rep., 2nd Ser. (Geol.), 41:129-195.

Peterson, L. C., and Prell, W. L., 1985a. Carbonate dissolution in Recent sediments of the eastern equatorian Indian Ocean: preservation and carbonate loss above the lysocline. Mar. Geol., 64:259-290. $1985 \mathrm{~b}$. Carbonate preservation and rates of climatic change: an $800 \mathrm{kyr}$ record from the Indian Ocean. In Sundquist, E. T., and Broecker, W. S. (Eds.), The Carbon Cycle and Atmospheric $\mathrm{Co}_{2}$ : Natural Variations Archean to Present. Am. Geophys. Union Monogr., 32:251-269.

Pisias, N. G., and Rea, D. K., 1988. Late Pleistocene paleoclimatology of the central equatorial Pacific: sea-surface temperature response to the southeast tradewinds. Paleoceanography, 3:21-37.

Pisias, N. G., Heath, R. G., and Moore, T. C., 1975. Lag times for oceanic responses to climatic change. Nature, 256:716-717.

Prell, W. L., 1982. Oxygen and carbon isotope stratigraphy for the Quaternary of Hole 502B: evidence for two modes of isotopic variability. In Prell, W. L., Gardner, J. F., et al., Init.Repts. DSDP, 68: Washington (U.S. Govt. Printing Office), 455-464.

Reymer, J.J.G., Schlager, W., and Droxler, A. W., 1988. ODP Site 632 Plio-Pleistocene sedimentation cycles in a Bahamian Basin. In Austin, J. A., Jr., Schlager, W., et al., Proc. ODP, Sci. Results, 101: College Station, TX (Ocean Drilling Program), 213-220.

Ruddiman, W. F., McIntyre, A., and Raymo, M., 1987. Paleo-environmental results from North Atlantic Sites 607 and 609. In Ruddiman, W. F., Kidd, R., Thomas, E., et al., Init. Repts. DSDP, 94, Pt. 2: Washington (U.S. Govt. Printing Office), 855-878.

Ruddiman, W. F., Raymo, M., and McIntyre, A., 1986. Matuyama 41,000-year cycles: North Atlantic Ocean and Northern Hemisphere ice sheets. Earth Planet. Sci. Lett., 80:117-129.

Saito, T., Burckle, L. H., and Hays, J. D., 1975. Late Miocene to Pleistocene biostratigraphy of equatorial Pacific sediments. In Saito, T., and Burckle, L. H. (Eds.), Late Neogene Epoch Boundaries: New York (Micropaleontology Press), 226-244.

Schlager, W., and Chermark, A., 1979. Modern sediment facies of platform-basin transition, Tongue of the Ocean, Bahamas. In Doyle, L., and Pilkey, O. H. (Eds.), Geological Continental Slopes. Spec. Publ., Soc. Econ. Paleontol. Mineral., 27:193-208.

Schlager, W., and James, N. P., 1978. Low-magnesian calcite limestones forming at the deep-sea floor, Tongue of the Ocean, Bahamas. Sedimentology, 15:675-702.
Shackleton, N. J., 1986. The Plio-Pleistocene Ocean: stable isotope history. In Hsü, K. J. (Ed.), Mesozoic and Cenozoic Oceans: Washington (American Geophysical Union), Geodyn. Ser., 15:141-153.

Shackleton, N. J., and Opdyke, N. D., 1973. Oxygen isotope and palaeomagnetic stratigraphy of equatorial Pacific core V28-238: oxygen isotope temperatures and ice volumes on a $10^{5}$ year and $10^{6}$ year scale. Quat. Res., 3:39-55.

1976. Oxygen isotope and paleomagnetic stratigraphy of $\mathrm{Pa}-$ cific core V28-239, late Pliocene to latest Pleistocene. In Cline, R. M., and Hays, J. D. (Eds.), Investigations of Late Quaternary Paleoceanography and Paleoclimatology. Mem. Geol. Soc. Am., 145:449-464.

Shackleton, N. J., Backman, J., Zimmerman, H., Kent, D. V., Hall, M. A., Schnitker, D., Baldauf, J., Desprairies, A., Homrighausen, R., Huddlestun, P., Keene, J. B., Kaltenback, A. J., Krumsiek, K.A.O., Morton, A. C., Murray, J. W., and Westberg-Smith, J., 1984. Oxygen isotope calibration of the onset of ice-rafting in DSDP Site 552A: history of glaciation in the North Atlantic region. $\mathrm{Na}$ ture, 307:620-623.

Slowey, N. C., Neumann, A. C., and Baldwin, K. C., 1989. Seismic expression of Quaternary climatic cycles in the periplatform carbonate ooze of the northern Bahamas. Geol. Soc. Am. Bull., 101:15631573.

Supko, P. R., 1963. A quantitative X-ray diffraction method for the mineralogical analysis of carbonate sediments from Tongue of the Ocean [M.S. thesis]. Univ. of Miami, Coral Gables, FL.

Thierstein, H. R., Geitzenauer, K. R., Molfino, B., and Shackleton, N. J., 1977. Global synchroneity of late Quaternary coccolith datum levels: validation by oxygen isotopes. Geology, 5:400-405.

Thompson, P. R., and Saito, T., 1974. Pacific Pleistocene sediments: planktonic foraminifera dissolution cycles and geochronology. Geology, 2:333-335.

Van Donk, J., 1976. ${ }^{18} \mathrm{O}$ record of the Atlantic Ocean for the entire Pleistocene Epoch. In Cline, R. M., and Hays, J. D. (Eds.), Investigations of Late Quaternary Paleoceanography and Paleoclimatology. Mem. Geol. Soc. Am., 145:147-163.

Vincent, E., 1985. Distribution stratigraphique de la teneur en carbonate dans les sédiments néogènes et quaternaires de l'océan Pacifique. Bull. Soc. Gol. Fr., 8:915-924.

Volat, J., Pastouret, L., and Vergnaud-Grazzini, C., 1980. Dissolution and carbonate fluctuations in Pleistocene deep-sea cores: a review. Mar. Geol., 34:1-28.

Williams, D. F., Gribble, D., Healy-Williams, N., and Leschak, P., 1985. Dissolution and water-mass patterns in the southeast Indian Ocean, Part II: the Pleistocene record from Brunhes to Matuyama age sediments. Geol. Soc. Am. Bull., 96:190-202.

Williams, D. F., Thunell, R. C., Tappa, E., Rio, D., and Raffi, I., 1988. Chronology of the Pleistocene oxygen-isotope record: $0-1.88$ m.y. B.P. Palaeogeogr., Palaeoclimatol., Palaeoecol., 64:221-240.

Wilson, J. L., 1975. Carbonate Facies in Geologic History: Berlin-Heidelberg-New York (Springer-Verlag).

Date of initial receipt: 28 June 1989

Date of acceptance: 11 January 1990

Ms 115B-179 
APPENDIX A

Carbonate Mineralogy and Oxygen Isotope Data and Pteropod Ratios for Sediment Samples from Hole 716B.

\begin{tabular}{|c|c|c|c|c|c|c|c|c|c|c|}
\hline \multirow[b]{2}{*}{$\begin{array}{l}\text { Core, section, } \\
\text { interval }(\mathrm{cm})\end{array}$} & \multirow[b]{2}{*}{$\begin{array}{l}\text { Depth } \\
\text { (m) }\end{array}$} & \multirow[b]{2}{*}{$\begin{array}{l}\text { Time } \\
\text { (Ma) }\end{array}$} & \multirow[b]{2}{*}{$\begin{array}{c}\text { Carbonate } \\
(\%)\end{array}$} & \multirow[b]{2}{*}{$\begin{array}{l}\text { Fine } \\
\text { fraction } \\
(\%)\end{array}$} & \multicolumn{3}{|c|}{ Carbonate mineralogy } & & & \\
\hline & & & & & $\begin{array}{c}\text { Aragonite } \\
(\%)\end{array}$ & $\begin{array}{l}\text { Calcite } \\
(\%)\end{array}$ & $\begin{array}{l}\mathrm{Mg} \\
\text { calcite } \\
(\%)\end{array}$ & $\begin{array}{c}\delta^{18} \mathrm{O} \text { PDB } \\
\text { G. sacculifera } \\
(\% 0)\end{array}$ & $\begin{array}{c}\text { Aragonite } \\
\text { to total } \\
\text { sediment }(\%)\end{array}$ & $\begin{array}{l}\text { Pteropod } \\
\text { ratio }\end{array}$ \\
\hline $1 \mathrm{H}-1,20-22$ & 0.2 & 0.005 & 92 & 51 & 70 & 19 & 11 & -2.02 & 33 & 0.63 \\
\hline $1 \mathrm{H}-1,40-42$ & 0.4 & 0.010 & 93 & 49 & 71 & 16 & 13 & -1.73 & 32 & 0.65 \\
\hline $1 \mathrm{H}-1,60-62$ & 0.6 & 0.014 & 86 & 31 & 61 & 24 & 15 & -0.88 & 16 & 0.62 \\
\hline $1 \mathrm{H}-1,80-82$ & 0.8 & 0.019 & 82 & 25 & 52 & 33 & 15 & -0.75 & 11 & 0.64 \\
\hline $1 \mathrm{H}-1,100-102$ & 1.0 & 0.024 & 82 & 25 & 49 & 34 & 17 & -0.93 & 10 & 0.56 \\
\hline $1 \mathrm{H}-1,120-122$ & 1.2 & 0.031 & 83 & 26 & 49 & 42 & 9 & -0.93 & 10 & 0.59 \\
\hline $1 \mathrm{H}-1,140-142$ & 1.4 & 0.038 & 87 & 40 & 65 & 23 & 12 & -1.01 & 22 & 0.58 \\
\hline $1 \mathrm{H}-2,20-22$ & 1.7 & 0.049 & 92 & 49 & 65 & 24 & 11 & -1.27 & 29 & 0.44 \\
\hline $1 \mathrm{H}-2,40-42$ & 1.9 & 0.055 & 91 & 49 & 67 & 24 & 9 & -1.32 & 30 & 0.47 \\
\hline $1 \mathrm{H}-2,60-62$ & 2.1 & 0.065 & 91 & 43 & 56 & 34 & 10 & -0.85 & 22 & 0.50 \\
\hline $1 \mathrm{H}-2,80-82$ & 2.3 & 0.074 & 92 & 49 & 64 & 26 & 10 & -1.57 & 29 & 0.37 \\
\hline $1 \mathrm{H}-2,100-102$ & 2.5 & 0.080 & 92 & 40 & 64 & 26 & 11 & -2.02 & 23 & 0.52 \\
\hline $1 \mathrm{H}-2,120-122$ & 2.7 & 0.086 & 90 & 42 & 68 & 24 & 8 & -1.49 & 25 & 0.47 \\
\hline $1 \mathrm{H}-2,140-142$ & 2.9 & 0.092 & 90 & 54 & 69 & 23 & 8 & -1.58 & 34 & 0.45 \\
\hline $2 \mathrm{H}-1,20-22$ & 4.1 & 0.128 & 86 & 33 & 63 & 25 & 12 & -0.99 & 18 & 0.57 \\
\hline $2 \mathrm{H}-1,40-42$ & 4.3 & 0.139 & 87 & 36 & 65 & 23 & 12 & -0.86 & 20 & 0.61 \\
\hline $2 \mathrm{H}-1,60-62$ & 4.5 & 0.149 & 81 & 33 & 56 & 31 & 13 & -0.77 & 15 & 0.50 \\
\hline $2 \mathrm{H}-1,80-82$ & 4.7 & 0.160 & 80 & 28 & 56 & 34 & 10 & -0.52 & 13 & 0.52 \\
\hline $2 \mathrm{H}-1,100-102$ & 4.9 & 0.170 & 82 & 31 & 58 & 34 & 8 & -0.79 & 15 & 0.61 \\
\hline $2 \mathrm{H}-1,120-122$ & 5.1 & 0.181 & 85 & 46 & 66 & 27 & 7 & -0.71 & 26 & 0.38 \\
\hline $2 \mathrm{H}-1,140-142$ & 5.3 & 0.191 & 89 & 54 & 69 & 22 & 9 & -1.51 & 33 & 0.47 \\
\hline $2 \mathrm{H}-2,20-22$ & 5.6 & 0.198 & 91 & 51 & 75 & 18 & 7 & -1.35 & 35 & 0.43 \\
\hline $2 \mathrm{H}-2,40-42$ & 5.8 & 0.203 & 92 & 59 & 70 & 23 & 7 & -1.03 & 38 & 0.42 \\
\hline $2 \mathrm{H}-2,60-62$ & 6 & 0.208 & 91 & 59 & 71 & 23 & 6 & -0.91 & 38 & 0.49 \\
\hline $2 \mathrm{H}-2,80-82$ & 6.2 & 0.213 & 93 & 53 & 77 & 18 & 5 & -1.76 & 38 & 0.512 \\
\hline $2 \mathrm{H}-2,100-102$ & 6.4 & 0.218 & 91 & 33 & 72 & 22 & 6 & -1.30 & 22 & 0.70 \\
\hline $2 \mathrm{H}-2,120-122$ & 6.6 & 0.223 & 91 & 47 & 69 & 27 & 4 & -0.98 & 30 & 0.45 \\
\hline $2 \mathrm{H}-2,140-142$ & 6.8 & 0.229 & 90 & 56 & 70 & 24 & 6 & -1.05 & 35 & 0.44 \\
\hline $2 \mathrm{H}-3,20-22$ & 7.1 & 0.236 & 92 & 47 & 69 & 23 & 8 & -1.01 & 30 & 0.54 \\
\hline $2 \mathrm{H}-3,40-42$ & 7.3 & 0.241 & 92 & 26 & 79 & 16 & 5 & -1.63 & 19 & 0.65 \\
\hline $2 \mathrm{H}-3,60-62$ & 7.5 & 0.248 & 85 & 30 & 55 & 37 & 8 & -0.67 & 14 & 0.52 \\
\hline $2 \mathrm{H}-3,80-82$ & 7.7 & 0.259 & 85 & 27 & 60 & 32 & 8 & -0.65 & 14 & 0.61 \\
\hline $2 \mathrm{H}-3,100-102$ & 7.9 & 0.271 & 82 & 38 & 66 & 26 & 8 & -0.71 & 20 & 0.44 \\
\hline $2 \mathrm{H}-3,120-122$ & 8.1 & 0.283 & 85 & 53 & 68 & 26 & 6 & -0.87 & 30 & 0.36 \\
\hline $2 \mathrm{H}-3,140-142$ & 8.3 & 0.294 & 90 & 58 & 68 & 26 & 6 & & 35 & 0.44 \\
\hline $2 \mathrm{H}-4,20-22$ & 8.6 & 0.308 & 94 & 49 & 73 & 22 & 5 & -1.31 & 34 & 0.36 \\
\hline $2 \mathrm{H}-4,40-42$ & 8.8 & 0.312 & 90 & 60 & 77 & 18 & 5 & -1.04 & 42 & 0.29 \\
\hline $2 \mathrm{H}-4,60-62$ & 9 & 0.315 & 89 & 57 & 66 & 30 & 4 & -0.73 & 34 & 0.27 \\
\hline $2 \mathrm{H}-4,80-82$ & 9.2 & 0.318 & 92 & 66 & 61 & 36 & 3 & -0.60 & 37 & 0.18 \\
\hline $2 \mathrm{H}-4,100-102$ & 9.4 & 0.322 & 92 & 56 & 65 & 30 & 5 & -1.26 & 34 & 0.32 \\
\hline $2 \mathrm{H}-4,120-122$ & 9.6 & 0.325 & 92 & 38 & 74 & 22 & 4 & -1.60 & 26 & 0.28 \\
\hline $2 \mathrm{H}-4,140-142$ & 9.8 & 0.329 & 92 & 62 & 69 & 29 & 2 & -1.20 & 39 & 0.51 \\
\hline $2 \mathrm{H}-6,20-22$ & 10.1 & 0.334 & 94 & 69 & 71 & 27 & 2 & -1.62 & 46 & 0.30 \\
\hline $2 \mathrm{H}-6,40-42$ & 10.3 & 0.337 & 93 & 43 & 76 & 21 & 3 & -1.46 & 30 & 0.36 \\
\hline $2 \mathrm{H}-6,60-62$ & 10.5 & 0.342 & 84 & 26 & 64 & 33 & 3 & -0.46 & 14 & 0.28 \\
\hline $2 \mathrm{H}-6,80-82$ & 10.7 & 0.347 & 86 & 33 & 62 & 33 & 5 & -0.66 & 18 & 0.44 \\
\hline $2 \mathrm{H}-6,100-102$ & 10.9 & 0.352 & 87 & 35 & 66 & 29 & 5 & -0.95 & 20 & 0.43 \\
\hline $2 \mathrm{H}-6,120-122$ & 11.1 & 0.357 & 91 & 32 & 69 & 27 & 4 & -1.12 & 20 & 0.36 \\
\hline $2 \mathrm{H}-6,140-142$ & 11.3 & 0.362 & 92 & 46 & 67 & 29 & 4 & -1.36 & 28 & 0.20 \\
\hline $2 \mathrm{H}-6,20-22$ & 11.6 & 0.375 & 90 & 48 & 75 & 22 & 3 & -1.35 & 33 & 0.04 \\
\hline $2 \mathrm{H}-6,40-42$ & 11.8 & 0.383 & 89 & 52 & 70 & 30 & 0 & -1.53 & 32 & 0.32 \\
\hline $2 \mathrm{H}-6,60-62$ & 12 & 0.391 & 90 & 48 & 68 & 30 & 2 & -1.65 & 29 & 0.25 \\
\hline $2 \mathrm{H}-6,80-82$ & 12.2 & 0.400 & 93 & 45 & 82 & 18 & 0 & -1.834 & 34 & 0.25 \\
\hline $2 \mathrm{H}-6,100-102$ & 12.4 & 0.408 & 89 & 34 & 76 & 22 & 2 & -1.15 & 23 & 0.66 \\
\hline $2 \mathrm{H}-6,120-122$ & 12.6 & 0.417 & 87 & 42 & 68 & 32 & 0 & -1.08 & 25 & 0.26 \\
\hline $2 \mathrm{H}-6,140-142$ & 12.8 & 0.426 & 83 & 33 & 70 & 27 & 3 & -0.94 & 19 & 0.40 \\
\hline $2 \mathrm{H}-7,20-22$ & 13.1 & 0.446 & 84 & 35 & 66 & 30 & 4 & -0.35 & 20 & 0.472 \\
\hline $3 \mathrm{H}-1,20-22$ & 13.7 & 0.485 & 92 & 50 & 67 & 33 & 0 & -0.89 & 31 & 0.27 \\
\hline $3 \mathrm{H}-1,40-42$ & 13.9 & 0.488 & 94 & 43 & 68 & 32 & 0 & -0.96 & 28 & 0.34 \\
\hline $3 \mathrm{H}-1,60-62$ & 14.1 & 0.491 & 90 & 34 & 70 & 27 & 3 & -0.95 & 22 & 0.50 \\
\hline $3 \mathrm{H}-1,80-82$ & 14.3 & 0.495 & 88 & 34 & 68 & 31 & 1 & -0.88 & 20 & 0.43 \\
\hline $3 \mathrm{H}-1,100-102$ & 14.5 & 0.498 & 89 & 39 & 81 & 17 & 2 & -1.02 & 28 & 0.36 \\
\hline $3 \mathrm{H}-1,120-122$ & 14.7 & 0.501 & 93 & 38 & 76 & 24 & 0 & -1.12 & 27 & 0.45 \\
\hline $3 \mathrm{H}-1,140-142$ & 14.9 & 0.505 & 90 & 36 & 77 & 21 & 2 & -1.00 & 25 & 0.48 \\
\hline $3 \mathrm{H}-2,20-22$ & 15.2 & 0.509 & 89 & 43 & 73 & 24 & 3 & -0.89 & 28 & 0.56 \\
\hline $3 \mathrm{H}-2,40-42$ & 15.4 & 0.513 & 92 & 36 & 78 & 20 & 2 & -0.92 & 26 & 0.51 \\
\hline $3 \mathrm{H}-2,60-62$ & 15.6 & 0.516 & 93 & 56 & 68 & 29 & 3 & -1.10 & 36 & 0.40 \\
\hline $3 \mathrm{H}-2,80-82$ & 15.8 & 0.519 & 94 & 42 & 66 & 31 & 3 & -0.90 & 26 & 0.49 \\
\hline $3 \mathrm{H}-2,100-102$ & 16.0 & 0.522 & 92 & 35 & 69 & 28 & 3 & -0.99 & 22 & 0.56 \\
\hline $3 \mathrm{H}-2,120-122$ & 16.2 & 0.530 & 84 & 27 & 56 & 36 & 8 & -0.34 & 13 & 0.52 \\
\hline $3 \mathrm{H}-2,140-142$ & 16.4 & 0.543 & 87 & 30 & 61 & 35 & 4 & -0.53 & 16 & 0.60 \\
\hline $3 \mathrm{H}-3,20-22$ & 16.7 & 0.562 & 87 & 48 & 66 & 31 & 3 & -0.90 & 28 & 0.52 \\
\hline $3 \mathrm{H}-3,40-42$ & 16.9 & 0.568 & 91 & 45 & 69 & 28 & 3 & -0.75 & 28 & 0.49 \\
\hline
\end{tabular}


APPENDIX A (continued).

\begin{tabular}{|c|c|c|c|c|c|c|c|c|c|c|}
\hline \multirow[b]{2}{*}{$\begin{array}{l}\text { Core, section, } \\
\text { interval }(\mathrm{cm})\end{array}$} & \multirow[b]{2}{*}{$\begin{array}{l}\text { Depth } \\
\text { (m) }\end{array}$} & \multirow[b]{2}{*}{$\begin{array}{l}\text { Time } \\
(\mathrm{Ma})\end{array}$} & \multirow[b]{2}{*}{$\begin{array}{c}\text { Carbonate } \\
(\%)\end{array}$} & \multirow[b]{2}{*}{$\begin{array}{l}\text { Fine } \\
\text { fraction } \\
(\%)\end{array}$} & \multicolumn{3}{|c|}{ Carbonate mineralogy } & & & \\
\hline & & & & & $\begin{array}{l}\text { Aragonite } \\
(\%)\end{array}$ & $\begin{array}{c}\text { Calcite } \\
(\%)\end{array}$ & $\begin{array}{l}\mathrm{Mg} \\
\text { calcite } \\
(\%)\end{array}$ & $\begin{array}{c}\delta^{18} \mathrm{O} \text { PDB } \\
\text { G. sacculifera } \\
(\% 0)\end{array}$ & $\begin{array}{c}\text { Aragonite } \\
\text { to total } \\
\text { sediment }(\%)\end{array}$ & $\begin{array}{l}\text { Pteropod } \\
\text { ratio }\end{array}$ \\
\hline $3 \mathrm{H}-3,60-62$ & 17.1 & 0.571 & 91 & 38 & 67 & 30 & 3 & -0.65 & 23 & 0.52 \\
\hline $3 \mathrm{H}-3,80-82$ & 17.3 & 0.574 & 91 & 29 & 64 & 33 & 3 & -0.75 & 17 & 0.55 \\
\hline $3 \mathrm{H}-3,100-102$ & 17.5 & 0.578 & 87 & 30 & 63 & 32 & 5 & -0.67 & 17 & 0.51 \\
\hline $3 \mathrm{H}-3,120-122$ & 17.7 & 0.581 & 87 & 29 & 60 & 35 & 5 & -0.83 & 15 & 0.53 \\
\hline $3 \mathrm{H}-3,140-142$ & 17.9 & 0.584 & 90 & 28 & 62 & 33 & 5 & -0.84 & 16 & 0.46 \\
\hline $3 \mathrm{H}-4,20-22$ & 18.2 & 0.590 & 90 & 27 & 60 & 36 & 4 & -0.68 & 15 & 0.50 \\
\hline $3 \mathrm{H}-4,40-42$ & 18.4 & 0.593 & 90 & 42 & 64 & 32 & 4 & -1.01 & 24 & 0.51 \\
\hline $3 \mathrm{H}-4,60-62$ & 18.6 & 0.596 & 93 & 43 & 68 & 32 & 0 & -0.98 & 27 & \\
\hline $3 \mathrm{H}-4,80-82$ & 18.8 & 0.600 & 93 & 55 & 70 & 30 & 0 & -0.97 & 36 & \\
\hline $3 \mathrm{H}-4,100-102$ & 19.0 & 0.603 & 95 & 51 & 72 & 28 & 0 & -0.94 & 34 & \\
\hline $3 \mathrm{H}-4,120-122$ & 19.2 & 0.606 & 92 & 37 & 75 & 25 & 0 & -0.77 & 25 & \\
\hline $3 \mathrm{H}-4,140-142$ & 19.4 & 0.610 & 91 & 38 & 66 & 32 & 2 & -0.68 & 23 & \\
\hline $3 \mathrm{H}-5,20-22$ & 19.7 & 0.615 & 92 & 42 & 68 & 32 & 0 & -0.91 & 26 & \\
\hline $3 \mathrm{H}-5,40-42$ & 19.9 & 0.618 & 91 & 37 & 73 & 27 & 0 & -0.48 & 24 & \\
\hline $3 \mathrm{H}-5,60-62$ & 20.1 & 0.622 & 91 & 39 & 73 & 27 & 0 & -0.63 & 26 & \\
\hline $3 \mathrm{H}-5,80-82$ & 20.3 & 0.626 & 93 & 45 & 70 & 30 & 0 & -0.38 & 29 & \\
\hline $3 \mathrm{H}-5,100-102$ & 20.5 & 0.630 & 94 & 62 & 69 & 31 & 0 & -0.61 & 40 & \\
\hline $3 \mathrm{H}-5,120-122$ & 20.7 & 0.633 & 93 & 63 & 73 & 27 & 0 & -0.49 & 43 & \\
\hline $3 \mathrm{H}-5,140-142$ & 20.9 & 0.637 & 90 & 44 & 73 & 27 & 0 & -0.34 & 29 & \\
\hline $3 \mathrm{H}-6,20-22$ & 21.2 & 0.643 & 87 & 34 & 66 & 34 & 0 & -0.56 & 20 & \\
\hline $3 \mathrm{H}-6,40-42$ & 21.4 & 0.647 & 92 & 40 & 70 & 30 & 0 & -0.64 & 26 & \\
\hline $3 \mathrm{H}-6,60-62$ & 21.6 & 0.650 & 87 & 36 & 66 & 34 & 0 & -0.31 & 21 & \\
\hline $3 \mathrm{H}-6,80-82$ & 21.8 & 0.654 & 85 & 33 & 68 & 32 & 0 & -0.42 & 19 & \\
\hline $3 \mathrm{H}-6,100-102$ & 22.0 & 0.658 & 87 & 46 & 66 & 34 & 0 & -0.91 & 27 & \\
\hline $3 \mathrm{H}-6,120-122$ & 22.2 & 0.662 & 90 & 58 & 68 & 32 & 0 & -1.01 & 36 & \\
\hline $3 \mathrm{H}-6,140-142$ & 22.4 & 0.665 & 95 & 53 & 70 & 30 & 0 & -0.75 & 35 & \\
\hline $4 \mathrm{H}-1,20-22$ & 23.3 & 0.680 & 91 & 48 & 68 & 32 & 0 & -0.78 & 30 & \\
\hline $4 \mathrm{H}-1,40-42$ & 23.5 & 0.684 & 90 & 47 & 71 & 29 & 0 & -1.11 & 30 & \\
\hline $4 \mathrm{H}-1,60-62$ & 23.7 & 0.687 & 91 & 37 & 68 & 32 & 0 & -0.50 & 23 & \\
\hline $4 \mathrm{H}-1,80-82$ & 23.9 & 0.695 & 92 & 43 & 46 & 54 & 0 & -0.53 & 18 & \\
\hline $4 \mathrm{H}-1,100-102$ & 24.1 & 0.706 & 89 & 43 & 62 & 38 & 0 & -0.97 & 23 & \\
\hline $4 \mathrm{H}-1,120-122$ & 24.3 & 0.717 & 89 & 46 & 71 & 29 & 0 & -0.67 & 29 & \\
\hline $4 \mathrm{H}-1,140-142$ & 24.5 & 0.729 & 88 & 62 & 68 & 32 & 0 & -1.03 & 37 & \\
\hline $4 \mathrm{H}-2,20-22$ & 24.8 & 0.729 & 92 & 28 & 80 & 20 & 0 & -0.48 & 20 & \\
\hline $4 \mathrm{H}-2,40-42$ & 25.0 & 0.731 & 92 & 34 & 68 & 32 & 0 & -0.50 & 21 & \\
\hline $4 H-2,60-62$ & 25.2 & 0.733 & 91 & 34 & 71 & 29 & 0 & -0.85 & 22 & \\
\hline $4 \mathrm{H}-2,80-82$ & 25.4 & 0.734 & 90 & 36 & 72 & 28 & 0 & -0.37 & 24 & \\
\hline $4 \mathrm{H}-2,100-102$ & 25.6 & 0.736 & 84 & 35 & 68 & 32 & 0 & -0.41 & 20 & \\
\hline $4 \mathrm{H}-2,120-122$ & 25.8 & 0.743 & 86 & 34 & 67 & 33 & 0 & -0.57 & 20 & \\
\hline $4 \mathrm{H}-2,140-142$ & 26.0 & 0.750 & 86 & 38 & 75 & 25 & 0 & -0.56 & 24 & \\
\hline $4 \mathrm{H}-3,20-22$ & 26.3 & 0.761 & 92 & 42 & 71 & 29 & 0 & -0.63 & 27 & \\
\hline $4 \mathrm{H}-3,40-42$ & 26.5 & 0.767 & 94 & 44 & 80 & 20 & 0 & -0.80 & 33 & \\
\hline $4 \mathrm{H}-3,60-62$ & 26.7 & 0.773 & 94 & 31 & 72 & 28 & 0 & -0.77 & 21 & \\
\hline $4 \mathrm{H}-3,80-82$ & 26.9 & 0.779 & 91 & 25 & 69 & 31 & 0 & -0.89 & 16 & \\
\hline $4 \mathrm{H}-3,100-102$ & 27.1 & 0.784 & 92 & 28 & 63 & 27 & 0 & -0.69 & 16 & \\
\hline $4 \mathrm{H}-3,120-122$ & 27.3 & 0.790 & 91 & 27 & 71 & 29 & 0 & -0.41 & 18 & \\
\hline $4 \mathrm{H}-3,140-142$ & 27.5 & 0.795 & 91 & 27 & 69 & 31 & 0 & -0.86 & 17 & \\
\hline $4 \mathrm{H}-4,20-22$ & 27.8 & 0.803 & 91 & 35 & 68 & 32 & 0 & -0.66 & 22 & \\
\hline $4 \mathrm{H}-4,40-42$ & 28.0 & 0.808 & 92 & 32 & 71 & 29 & 0 & -0.74 & 21 & \\
\hline $4 \mathrm{H}-4,60-62$ & 28.2 & 0.813 & 95 & 46 & 71 & 29 & 0 & -0.97 & 31 & \\
\hline $4 \mathrm{H}-4,80-82$ & 28.4 & 0.818 & 93 & 35 & 77 & 22 & 1 & -0.94 & 25 & \\
\hline $4 \mathrm{H}-4,100-102$ & 28.6 & 0.822 & 92 & 25 & 69 & 31 & 0 & -0.92 & 16 & \\
\hline $4 \mathrm{H}-4,120-122$ & 28.8 & 0.827 & 93 & 34 & 69 & 31 & 0 & -1.10 & 22 & \\
\hline $4 \mathrm{H}-4,140-142$ & 29.0 & 0.831 & 94 & 30 & 71 & 26 & 3 & -1.10 & 20 & \\
\hline $4 \mathrm{H}-5,20-22$ & 29.3 & 0.838 & 95 & 18 & 67 & 28 & 5 & -1.51 & 11 & \\
\hline $4 \mathrm{H}-5,40-42$ & 29.5 & 0.843 & 95 & 23 & 67 & 25 & 8 & -1.45 & 15 & \\
\hline $4 \mathrm{H}-5,60-62$ & 29.7 & 0.847 & 95 & 22 & 61 & 32 & 7 & -1.09 & 13 & \\
\hline $4 \mathrm{H}-5,80-82$ & 29.9 & 0.852 & 97 & 18 & 68 & 24 & 8 & -1.08 & 12 & \\
\hline $4 \mathrm{H}-5,100-102$ & 30.1 & 0.856 & 96 & 14 & 60 & 32 & 8 & -0.95 & 8 & \\
\hline $4 \mathrm{H}-5,120-122$ & 30.3 & 0.861 & 97 & 20 & 60 & 34 & 6 & -1.21 & 12 & \\
\hline $4 \mathrm{H}-5,140-142$ & 30.5 & 0.866 & 95 & 20 & 62 & 31 & 7 & -1.10 & 12 & \\
\hline $4 \mathrm{H}-6,20-22$ & 30.8 & 0.872 & 97 & 14 & 66 & 26 & 8 & -1.23 & 9 & \\
\hline $4 \mathrm{H}-6,40-42$ & 31.0 & 0.878 & 95 & 15 & 65 & 23 & 12 & -1.06 & 9 & \\
\hline $4 \mathrm{H}-6,60-62$ & 31.2 & 0.882 & 96 & 14 & 60 & 31 & 9 & -1.33 & 8 & \\
\hline $4 \mathrm{H}-6,80-82$ & 31.4 & 0.886 & 93 & 17 & 63 & 31 & 6 & -1.20 & 10 & \\
\hline $4 \mathrm{H}-6,100-102$ & 31.6 & 0.891 & 94 & 16 & 62 & 32 & 6 & -1.15 & 9 & \\
\hline $4 \mathrm{H}-6,120-122$ & 31.8 & 0.895 & 95 & 12 & 58 & 34 & 8 & -1.27 & 7 & \\
\hline $5 \mathrm{H}-1,20-22$ & 33.0 & 0.920 & 92 & 25 & 66 & 34 & 0 & -0.83 & 15 & \\
\hline $5 \mathrm{H}-1,40-42$ & 33.2 & 0.922 & 85 & 34 & 64 & 36 & 0 & -0.63 & 18 & \\
\hline $5 \mathrm{H}-1,60-62$ & 33.4 & 0.924 & 85 & 35 & 63 & 37 & 0 & -0.96 & 19 & \\
\hline $5 \mathrm{H}-1,80-82$ & 33.6 & 0.927 & 89 & 40 & 66 & 34 & 0 & -1.01 & 23 & \\
\hline $5 \mathrm{H}-1,100-102$ & 33.8 & 0.929 & 91 & 38 & 67 & 31 & 2 & -1.03 & 23 & \\
\hline $5 \mathrm{H}-1,120-122$ & 34.0 & 0.933 & 91 & 26 & 66 & 34 & 0 & -1.01 & 15 & \\
\hline $5 \mathrm{H}-1,140-142$ & 34.2 & 0.939 & 91 & 31 & 65 & 35 & 0 & -1.21 & 19 & \\
\hline
\end{tabular}


APPENDIX A (continued).

\begin{tabular}{|c|c|c|c|c|c|c|c|c|c|c|}
\hline \multirow[b]{2}{*}{$\begin{array}{l}\text { Core, section, } \\
\text { interval }(\mathrm{cm})\end{array}$} & \multirow[b]{2}{*}{$\begin{array}{l}\text { Depth } \\
\text { (m) }\end{array}$} & \multirow[b]{2}{*}{$\begin{array}{l}\text { Time } \\
\text { (Ma) }\end{array}$} & \multirow[b]{2}{*}{$\begin{array}{c}\text { Carbonate } \\
(\%)\end{array}$} & \multirow[b]{2}{*}{$\begin{array}{l}\text { Fine } \\
\text { fraction } \\
(\%)\end{array}$} & \multicolumn{3}{|c|}{ Carbonate mineralogy } & & & \\
\hline & & & & & $\begin{array}{l}\text { Aragonite } \\
(\%)\end{array}$ & $\begin{array}{c}\text { Calcite } \\
(\%)\end{array}$ & $\begin{array}{l}\mathrm{Mg} \\
\text { calcite } \\
(\%)\end{array}$ & $\begin{array}{c}\delta^{18} \mathrm{O} \text { PDB } \\
\text { G. sacculifera } \\
(\% 0)\end{array}$ & $\begin{array}{c}\text { Aragonite } \\
\text { to total } \\
\text { sediment }(\%)\end{array}$ & $\begin{array}{l}\text { Pteropod } \\
\text { ratio }\end{array}$ \\
\hline $5 \mathrm{H}-2,20-22$ & 34.5 & 0.948 & 93 & 37 & 67 & 33 & 0 & -1.00 & 23 & \\
\hline $5 \mathrm{H}-2,40-42$ & 34.7 & 0.955 & 91 & 38 & 68 & 32 & 0 & -1.37 & 24 & \\
\hline $5 \mathrm{H}-2,60-62$ & 34.9 & 0.961 & 94 & 32 & 69 & 31 & 0 & -0.95 & 21 & \\
\hline $5 \mathrm{H}-2,80-82$ & 35.1 & 0.967 & 92 & 35 & 63 & 37 & 0 & -1.07 & 20 & \\
\hline $5 \mathrm{H}-2,100-102$ & 35.3 & 0.973 & 92 & 42 & 67 & 33 & 0 & -1.26 & 26 & \\
\hline $5 \mathrm{H}-2,120-122$ & 35.5 & 0.979 & 94 & 54 & 69 & 31 & 0 & -1.09 & 35 & \\
\hline $5 \mathrm{H}-2,140-142$ & 35.7 & 0.985 & 93 & 37 & 68 & 32 & 0 & -1.15 & 24 & \\
\hline $5 \mathrm{H}-3,2 \mathrm{O}-22$ & 36.0 & 0.995 & 91 & 43 & 68 & 32 & 0 & -0.99 & 27 & \\
\hline $5 \mathrm{H}-3,40-42$ & 36.2 & 1.001 & 92 & 46 & 67 & 33 & 0 & -0.79 & 28 & \\
\hline $5 \mathrm{H}-3,60-62$ & 36.4 & 1.007 & 94 & 54 & 70 & 30 & 0 & -0.92 & 36 & \\
\hline $5 \mathrm{H}-3,80-82$ & 36.6 & 1.010 & 94 & 62 & 71 & 29 & 0 & -0.78 & 41 & \\
\hline $5 \mathrm{H}-3,100-102$ & 36.8 & 1.014 & 95 & 53 & 69 & 31 & 0 & -0.93 & 34 & \\
\hline $5 \mathrm{H}-3,120-122$ & 37.0 & 1.017 & 93 & 48 & 65 & 35 & 0 & -0.88 & 29 & \\
\hline $5 \mathrm{H}-3,140-142$ & 37.2 & 1.020 & 92 & 54 & 61 & 39 & 0 & -0.76 & 30 & \\
\hline $5 \mathrm{H}-4,20-22$ & 37.5 & 1.025 & 93 & 56 & 62 & 38 & 0 & -0.66 & 33 & \\
\hline $5 \mathrm{H}-4,40-42$ & 37.7 & 1.028 & 95 & 51 & 58 & 42 & 0 & -0.69 & 28 & \\
\hline $5 \mathrm{H}-4,60-62$ & 37.9 & 1.031 & 96 & 67 & 66 & 34 & 0 & -0.89 & 43 & \\
\hline $5 \mathrm{H}-4,80-82$ & 38.1 & 1.035 & 96 & 55 & 75 & 25 & 0 & -0.58 & 40 & \\
\hline $5 \mathrm{H}-4,100-102$ & 38.3 & 1.038 & 96 & 54 & 69 & 31 & 0 & -0.33 & 36 & \\
\hline $5 \mathrm{H}-4,120-122$ & 38.5 & 1.041 & 94 & 45 & 71 & 29 & 0 & -0.26 & 30 & \\
\hline $5 \mathrm{H}-4,140-142$ & 38.7 & 1.046 & 96 & 62 & 68 & 32 & 0 & -0.45 & 40 & \\
\hline $5 \mathrm{H}-5,20-22$ & 39.0 & 1.063 & 94 & 52 & 73 & 27 & 0 & -0.36 & 36 & \\
\hline $5 \mathrm{H}-5,40-42$ & 39.2 & 1.074 & 92 & 46 & 70 & 30 & 0 & -0.05 & 30 & \\
\hline $5 \mathrm{H}-5,60-62$ & 39.4 & 1.085 & 92 & 43 & 71 & 29 & 0 & -0.29 & 28 & \\
\hline $5 \mathrm{H}-5,80-82$ & 39.6 & 1.096 & 91 & 42 & 69 & 31 & 0 & -0.34 & 26 & \\
\hline $5 \mathrm{H}-5,100-102$ & 39.8 & 1.107 & 94 & 48 & 68 & 32 & 0 & -0.37 & 30 & \\
\hline $5 \mathrm{H}-5,120-122$ & 40.0 & 1.118 & 93 & 53 & 70 & 30 & 0 & -0.61 & 35 & \\
\hline $5 \mathrm{H}-5,140-142$ & 40.2 & 1.129 & 93 & 70 & 68 & 32 & 0 & -0.60 & 44 & \\
\hline $5 \mathrm{H}-6,20-22$ & 40.5 & 1.146 & 95 & 72 & 58 & 42 & 0 & -0.83 & 39 & \\
\hline $5 \mathrm{H}-6,40-42$ & 40.7 & 1.157 & 96 & 70 & 59 & 41 & 0 & -0.65 & 40 & \\
\hline $5 \mathrm{H}-6,60-62$ & 40.9 & 1.169 & 96 & 69 & 62 & 38 & 0 & -0.26 & 41 & \\
\hline $5 \mathrm{H}-6,80-82$ & 41.1 & 1.180 & 99 & 57 & 73 & 27 & 0 & & 42 & \\
\hline $5 \mathrm{H}-6,100-102$ & 41.3 & 1.191 & 99 & 48 & 72 & 28 & 0 & & 34 & \\
\hline $5 \mathrm{H}-6,120-122$ & 41.5 & 1.202 & 97 & 39 & 71 & 29 & 0 & & 27 & \\
\hline $5 \mathrm{H}-6,140-142$ & 41.7 & 1.213 & 98 & 42 & 70 & 30 & 0 & & 29 & \\
\hline $5 \mathrm{H}-7,20-22$ & 42.0 & 1.230 & 97 & 52 & 68 & 32 & 0 & & 35 & \\
\hline $5 \mathrm{H}-7,40-42$ & 42.2 & 1.241 & 99 & 51 & 71 & 29 & 0 & & 36 & \\
\hline $5 \mathrm{H}-7,60-62$ & 42.4 & 1.252 & 98 & 56 & 72 & 28 & 0 & & 40 & \\
\hline $5 \mathrm{H}-7,80-82$ & 42.6 & 1.264 & 98 & 50 & 75 & 25 & 0 & & 37 & \\
\hline $6 \mathrm{H}-1,20-22$ & 42.7 & 1.294 & 96 & 49 & 68 & 32 & 0 & & 32 & \\
\hline $6 \mathrm{H}-1,40-42$ & 42.9 & 1.305 & 97 & 42 & 67 & 33 & 0 & & 27 & \\
\hline $6 \mathrm{H}-1,60-62$ & 43.1 & 1.317 & 97 & 43 & 61 & 39 & 0 & & 25 & \\
\hline $6 \mathrm{H}-1,80-82$ & 43.3 & 1.336 & 96 & 40 & 66 & 34 & 0 & & 26 & \\
\hline $6 \mathrm{H}-1,100-102$ & 43.5 & 1.339 & 97 & 47 & 65 & 35 & 0 & & 30 & \\
\hline $6 \mathrm{H}-1,120-122$ & 43.7 & 1.342 & 97 & 45 & 66 & 34 & 0 & & 29 & \\
\hline $6 \mathrm{H}-1,140-142$ & 43.9 & 1.344 & 97 & 47 & 67 & 33 & 0 & & 30 & \\
\hline $6 \mathrm{H}-2,20-22$ & 44.2 & 1.348 & 98 & 51 & 67 & 33 & 0 & & 33 & \\
\hline $6 \mathrm{H}-2,40-42$ & 44.4 & 1.351 & 97 & 47 & 67 & 33 & 0 & & 30 & \\
\hline $6 \mathrm{H}-2,60-62$ & 44.6 & 1.353 & 95 & 62 & 52 & 48 & 0 & & 31 & \\
\hline $6 \mathrm{H}-2,80-82$ & 44.8 & 1.356 & 93 & 61 & 61 & 39 & 0 & & 35 & \\
\hline $6 \mathrm{H}-2,100-102$ & 45.0 & 1.359 & 94 & 69 & 64 & 36 & 0 & & 42 & \\
\hline $6 \mathrm{H}-2,120-122$ & 45.2 & 1.361 & 94 & 53 & 61 & 39 & 0 & & 31 & \\
\hline $6 \mathrm{H}-2,140-142$ & 45.4 & 1.364 & 95 & 62 & 60 & 40 & 0 & & 35 & \\
\hline $6 \mathrm{H}-3,20-22$ & 45.7 & 1.368 & 95 & 61 & 56 & 44 & 0 & & 32 & \\
\hline $6 \mathrm{H}-3,40-42$ & 45.9 & 1.371 & 94 & 69 & 56 & 44 & 0 & & 36 & \\
\hline $6 \mathrm{H}-3,60-62$ & 46.1 & 1.373 & 97 & 66 & 47 & 53 & 0 & & 30 & \\
\hline $6 \mathrm{H}-3,80-82$ & 46.3 & 1.376 & 95 & 54 & 57 & 43 & 0 & & 29 & \\
\hline $6 \mathrm{H}-3,100-102$ & 46.5 & 1.379 & 97 & 49 & 62 & 38 & 0 & & 29 & \\
\hline $6 \mathrm{H}-3,120-122$ & 46.7 & 1.381 & 97 & 51 & 58 & 42 & 0 & & 29 & \\
\hline $6 \mathrm{H}-3,140-142$ & 46.9 & 1.384 & 96 & 58 & 62 & 38 & 0 & & 34 & \\
\hline $6 \mathrm{H}-4,20-22$ & 47.2 & 1.388 & 96 & 66 & 55 & 45 & 0 & & 35 & \\
\hline $6 \mathrm{H}-4,40-42$ & 47.4 & 1.390 & 95 & 60 & 57 & 43 & 0 & & 32 & \\
\hline $6 \mathrm{H}-4,60-62$ & 47.6 & 1.393 & 96 & 55 & 55 & 45 & 0 & & 29 & \\
\hline $6 \mathrm{H}-4,80-82$ & 47.8 & 1.396 & 96 & 50 & 61 & 39 & 0 & & 29 & \\
\hline $6 \mathrm{H}-4,100-102$ & 48.0 & 1.398 & 96 & 56 & 62 & 38 & 0 & & 33 & \\
\hline $6 \mathrm{H}-4,120-122$ & 48.2 & 1.401 & 98 & 58 & 62 & 38 & 0 & & 35 & \\
\hline $6 \mathrm{H}-4,140-142$ & 48.4 & 1.402 & 96 & 54 & 60 & 40 & 0 & & 32 & \\
\hline $6 \mathrm{H}-5,20-22$ & 48.7 & 1.407 & 97 & 52 & 60 & 40 & 0 & & 30 & \\
\hline $6 \mathrm{H}-5,40-42$ & 48.9 & 1.410 & 96 & 53 & 46 & 54 & 0 & & 23 & \\
\hline $6 \mathrm{H}-5,60-62$ & 49.1 & 1.412 & 97 & 54 & 52 & 48 & 0 & & 27 & \\
\hline $6 \mathrm{H}-5,80-82$ & 49.3 & 1.415 & 98 & 61 & 55 & 45 & 0 & & 32 & \\
\hline $6 \mathrm{H}-5,100-102$ & 49.5 & 1.418 & 97 & 55 & 49 & 51 & 0 & & 26 & \\
\hline $6 \mathrm{H}-5,120-122$ & 49.7 & 1.421 & 97 & 55 & 54 & 46 & 0 & & 28 & \\
\hline $6 \mathrm{H}-5,140-142$ & 49,9 & 1.423 & 96 & 46 & 50 & 50 & 0 & & 22 & \\
\hline
\end{tabular}


APPENDIX A (continued).

\begin{tabular}{|c|c|c|c|c|c|c|c|c|c|c|}
\hline \multirow[b]{2}{*}{$\begin{array}{l}\text { Core, section, } \\
\text { interval (cm) }\end{array}$} & \multirow[b]{2}{*}{$\begin{array}{l}\text { Depth } \\
\text { (m) }\end{array}$} & \multirow[b]{2}{*}{$\begin{array}{l}\text { Time } \\
\text { (Ma) }\end{array}$} & \multirow[b]{2}{*}{$\begin{array}{c}\text { Carbonate } \\
(\%)\end{array}$} & \multirow[b]{2}{*}{$\begin{array}{l}\text { Fine } \\
\text { fraction } \\
(\%)\end{array}$} & Carbor & te minera & ogy & & & \\
\hline & & & & & $\begin{array}{c}\text { Aragonite } \\
\text { (\%) }\end{array}$ & $\begin{array}{c}\text { Calcite } \\
(\%)\end{array}$ & $\begin{array}{l}\mathrm{Mg} \\
\text { calcite } \\
(\%)\end{array}$ & $\begin{array}{c}\delta^{18} \mathrm{O} \text { PDB } \\
\text { G. sacculifera } \\
(\%(\%)\end{array}$ & $\begin{array}{c}\text { Aragonite } \\
\text { to total } \\
\text { sediment }(\%)\end{array}$ & $\begin{array}{l}\text { Pteropod } \\
\text { ratio }\end{array}$ \\
\hline $6 \mathrm{H}-6,20-22$ & 50.2 & 1.427 & 96 & 41 & 47 & 53 & 0 & & 18 & \\
\hline $6 \mathrm{H}-6,40-42$ & 50.4 & 1.430 & 97 & 57 & 53 & 47 & 0 & & 30 & \\
\hline $6 \mathrm{H}-6,60-62$ & 50.6 & 1.433 & 98 & 58 & 52 & 48 & 0 & & 30 & \\
\hline $6 \mathrm{H}-6,80-82$ & 50.8 & 1.435 & 95 & 61 & 52 & 48 & 0 & & 30 & \\
\hline $6 \mathrm{H}-6,100-102$ & 51.0 & 1.438 & 94 & 48 & 60 & 40 & 0 & & 27 & \\
\hline $6 \mathrm{H}-6,120-122$ & 51.2 & 1.441 & 94 & 51 & 56 & 44 & 0 & & 27 & \\
\hline $6 \mathrm{H}-6,140-142$ & 51.4 & 1.443 & 95 & 48 & 57 & 43 & 0 & & 26 & \\
\hline $6 \mathrm{H}-7,20-22$ & 51.7 & 1.447 & 96 & 51 & 58 & 42 & 0 & & 28 & \\
\hline $6 \mathrm{H}-7,40-42$ & 51.9 & 1.450 & 95 & 52 & 56 & 44 & 0 & & 27 & \\
\hline $6 \mathrm{H}-7,60-62$ & 52.1 & 1.452 & 95 & 55 & 60 & 40 & 0 & & 31 & \\
\hline $6 \mathrm{H}-7,80-82$ & 52.3 & 1.455 & 96 & 52 & 61 & 39 & 0 & & 31 & \\
\hline $7 \mathrm{H}-1,20-22$ & 51.31 & 1.455 & 94 & 60 & 50 & 50 & 0 & & 28 & \\
\hline $7 \mathrm{H}-1,40-42$ & 52.5 & 1.463 & 95 & 60 & 47 & 53 & 0 & & 27 & \\
\hline $7 \mathrm{H}-1,60-62$ & 52.7 & 1.471 & 92 & 65 & 51 & 49 & 0 & & 31 & \\
\hline $7 \mathrm{H}-1,80-82$ & 52.9 & 1.480 & 94 & 53 & 43 & 57 & 0 & & 21 & \\
\hline $7 \mathrm{H}-1,100-102$ & 53.1 & 1.488 & 95 & 52 & 55 & 45 & 0 & & 27 & \\
\hline $7 \mathrm{H}-1,120-122$ & 53.3 & 1.496 & 95 & 54 & 41 & 59 & 0 & & 21 & \\
\hline $7 \mathrm{H}-1,140-142$ & 53.5 & 1.504 & & 16 & & & & & & \\
\hline $7 \mathrm{H}-2,20-22$ & 53.8 & 1.516 & 93 & 63 & 58 & 42 & 0 & & 34 & \\
\hline $7 \mathrm{H}-2,40-42$ & 54.0 & 1.524 & 94 & 66 & 52 & 48 & 0 & & 32 & \\
\hline $7 \mathrm{H}-2,60-62$ & 54.2 & 1.533 & 93 & 67 & 55 & 45 & 0 & & 34 & \\
\hline $7 \mathrm{H}-2,80-82$ & 54.4 & 1.541 & 92 & 68 & 55 & 45 & 0 & & 34 & \\
\hline $7 \mathrm{H}-2,100-102$ & 54.6 & 1.549 & 93 & 48 & 54 & 46 & 0 & & 24 & \\
\hline $7 \mathrm{H}-2,120-122$ & 54.8 & 1.557 & 94 & 45 & 52 & 48 & 0 & & 22 & \\
\hline $7 \mathrm{H}-2,140-142$ & 55.0 & 1.565 & & 77 & & & & & & \\
\hline $7 \mathrm{H}-3,20-22$ & 55.3 & 1.578 & 95 & 70 & 52 & 48 & 0 & & 35 & \\
\hline $7 \mathrm{H}-3,40-42$ & 55.5 & 1.586 & 95 & 61 & 57 & 43 & 0 & & 33 & \\
\hline $7 \mathrm{H}-3,60-62$ & 55.7 & 1.594 & 93 & 55 & 58 & 42 & 0 & & 30 & \\
\hline $7 \mathrm{H}-3,80-82$ & 55.9 & 1.602 & 94 & 53 & 43 & 57 & 0 & & 21 & \\
\hline $7 \mathrm{H}-3,100-102$ & 56.1 & 1.610 & 94 & 49 & 55 & 45 & 0 & & 25 & \\
\hline $7 \mathrm{H}-3,120-122$ & 56.3 & 1.618 & 93 & 47 & 70 & 30 & 0 & & 31 & \\
\hline $7 \mathrm{H}-3,140-142$ & 56.5 & 1.627 & 92 & 54 & 71 & 29 & 0 & & 35 & \\
\hline $7 \mathrm{H}-4,20-22$ & 56.8 & 1.639 & 94 & 52 & 67 & 33 & 0 & & 33 & \\
\hline $7 \mathrm{H}-4,40-42$ & 57.0 & 1.647 & 94 & 55 & 71 & 29 & 0 & & 37 & \\
\hline $7 \mathrm{H}-4,60-62$ & 57.2 & 1.655 & 94 & 52 & 68 & 32 & 0 & & 33 & \\
\hline $7 \mathrm{H}-4,80-82$ & 57.4 & 1.663 & 94 & 58 & 65 & 35 & 0 & & 35 & \\
\hline $7 \mathrm{H}-4,100-102$ & 57.6 & 1.671 & 94 & 57 & 62 & 38 & 0 & & 33 & \\
\hline $7 \mathrm{H}-4,120-122$ & 57.8 & 1.680 & 94 & 66 & 61 & 39 & 0 & & 38 & \\
\hline $7 \mathrm{H}-4,140-142$ & 58.0 & 1.688 & 94 & 71 & 58 & 42 & 0 & & 39 & \\
\hline $7 \mathrm{H}-5,20-22$ & 58.3 & 1.700 & 94 & 65 & 61 & 39 & 0 & & 37 & \\
\hline $7 \mathrm{H}-5,40-42$ & 58.5 & 1.708 & 92 & 74 & 51 & 49 & 0 & & 35 & \\
\hline $7 \mathrm{H}-5,60-62$ & 58.7 & 1.716 & 92 & 73 & 56 & 44 & 0 & & 38 & \\
\hline $7 \mathrm{H}-5,80-82$ & 58.9 & 1.725 & 92 & 79 & 61 & 39 & 0 & & 45 & \\
\hline $7 \mathrm{H}-5,100-102$ & 59.1 & 1.733 & 89 & 77 & 52 & 48 & 0 & & 36 & \\
\hline $7 \mathrm{H}-5,120-122$ & 59.3 & 1.741 & 92 & 71 & 46 & 54 & 0 & & 30 & \\
\hline $7 \mathrm{H}-5,140-142$ & 59.5 & 1.749 & 94 & 50 & 46 & 54 & 0 & & 22 & \\
\hline $7 \mathrm{H}-6,20-22$ & 59.8 & 1.761 & 95 & 61 & 63 & 37 & 0 & & 36 & \\
\hline $7 \mathrm{H}-6,40-42$ & 60.0 & 1.769 & 93 & 67 & 56 & 44 & 0 & & 35 & \\
\hline $7 \mathrm{H}-6,60-62$ & 60.2 & 1.778 & 97 & 72 & 50 & 50 & 0 & & 35 & \\
\hline $7 \mathrm{H}-6,80-82$ & 60.4 & 1.786 & 93 & 68 & 57 & 43 & 0 & & 36 & \\
\hline $7 \mathrm{H}-6,100-102$ & 60.6 & 1.794 & 92 & 65 & 66 & 34 & 0 & & 39 & \\
\hline $7 \mathrm{H}-6,120-122$ & 60.8 & 1.802 & 94 & 55 & 66 & 34 & 0 & & 34 & \\
\hline $7 \mathrm{H}-6,140-142$ & 61.0 & 1.810 & 91 & 69 & 69 & 31 & 0 & & 43 & \\
\hline $7 \mathrm{H}-7,20-22$ & 61.3 & 1.823 & 93 & 75 & 57 & 43 & 0 & & 39 & \\
\hline $7 \mathrm{H}-7,40-42$ & 61.5 & 1.831 & 93 & 72 & 51 & 49 & 0 & & 34 & \\
\hline $8 \mathrm{H}-1,20-22$ & 61.9 & 1.847 & 91 & 70 & 44 & 56 & 0 & & 28 & \\
\hline $8 \mathrm{H}-1,40-42$ & 62.1 & 1.855 & 93 & 67 & 46 & 54 & 0 & & 29 & \\
\hline $8 \mathrm{H}-1,60-62$ & 62.3 & 1.863 & 93 & 70 & 43 & 57 & 0 & & 28 & \\
\hline $8 \mathrm{H}-1,80-82$ & 62.5 & 1.872 & 93 & 72 & 51 & 49 & 0 & & 34 & \\
\hline $8 \mathrm{H}-1,100-102$ & 62.7 & 1.880 & 92 & 73 & 50 & 50 & 0 & & 34 & \\
\hline $8 \mathrm{H}-1,120-122$ & 62.9 & 1.888 & 93 & 75 & 39 & 61 & 0 & & 27 & \\
\hline $8 \mathrm{H}-1,140-142$ & 63.1 & 1.893 & 94 & 68 & 37 & 63 & 0 & & 24 & \\
\hline $8 \mathrm{H}-2,20-22$ & 63.4 & 1.899 & 93 & 66 & 39 & 61 & 0 & & 24 & \\
\hline $8 \mathrm{H}-2,40-42$ & 63.6 & 1.903 & 94 & 64 & 51 & 49 & 0 & & 31 & \\
\hline $8 \mathrm{H}-2,60-62$ & 63.8 & 1.908 & 96 & 54 & 54 & 46 & 0 & & 28 & \\
\hline $8 \mathrm{H}-2,80-82$ & 64.0 & 1.912 & 96 & 56 & 49 & 51 & 0 & & 26 & \\
\hline $8 \mathrm{H}-2,100-102$ & 64.2 & 1.916 & 95 & 60 & 40 & 60 & 0 & & 23 & \\
\hline $8 \mathrm{H}-2,120-122$ & 64.4 & 1.920 & 95 & 62 & 39 & 61 & 0 & & 23 & \\
\hline $8 \mathrm{H}-2,140-142$ & 64.6 & 1.924 & 94 & 58 & 43 & 57 & 0 & & 23 & \\
\hline $3 \mathrm{H}-3,20-22$ & 64.9 & 1.930 & 94 & 51 & 48 & 52 & 0 & & 23 & \\
\hline $3 \mathrm{H}-3,40-42$ & 65.1 & 1.934 & 93 & 58 & 60 & 40 & 0 & & 33 & \\
\hline $3 \mathrm{H}-3,60-62$ & 65.3 & 1.939 & 93 & 71 & 54 & 46 & 0 & & 35 & \\
\hline $3 \mathrm{H}-3,80-82$ & 65.5 & 1.943 & 94 & 64 & 53 & 47 & 0 & & 32 & \\
\hline $3 \mathrm{H}-3,100-102$ & 65.7 & 1.947 & 93 & 62 & 52 & 48 & 0 & & 30 & \\
\hline $3 \mathrm{H}-3,120-122$ & 65.9 & 1.951 & 94 & 32 & 50 & 50 & 0 & & 15 & \\
\hline $3 \mathrm{H}-3,140-142$ & 66.1 & 1.955 & 93 & 74 & 44 & 56 & 0 & & 30 & \\
\hline
\end{tabular}


APPENDIX A (continued).

\begin{tabular}{|c|c|c|c|c|c|c|c|c|c|c|}
\hline \multirow[b]{2}{*}{$\begin{array}{l}\text { Core, section, } \\
\text { interval }(\mathrm{cm})\end{array}$} & \multirow[b]{2}{*}{$\begin{array}{l}\text { Depth } \\
\text { (m) }\end{array}$} & \multirow[b]{2}{*}{$\begin{array}{l}\text { Time } \\
\text { (Ma) }\end{array}$} & \multirow[b]{2}{*}{$\begin{array}{c}\text { Carbonate } \\
(\%)\end{array}$} & \multirow[b]{2}{*}{$\begin{array}{l}\text { Fine } \\
\text { fraction } \\
(\%)\end{array}$} & Carbon & te minera & gy & & & \\
\hline & & & & & $\begin{array}{c}\text { Aragonite } \\
(\%)\end{array}$ & $\begin{array}{c}\text { Calcite } \\
(\%)\end{array}$ & $\begin{array}{l}\mathrm{Mg} \\
\text { calcite } \\
(\%)\end{array}$ & $\begin{array}{c}\delta^{18} \text { O PDB } \\
\text { G. sacculifera } \\
\left(\%_{00}\right)\end{array}$ & $\begin{array}{c}\text { Aragonite } \\
\text { to total } \\
\text { sediment }(\%)\end{array}$ & $\begin{array}{l}\text { Pteropod } \\
\text { ratio }\end{array}$ \\
\hline $3 \mathrm{H}-4,20-22$ & 66.4 & 1.961 & 93 & 60 & 46 & 54 & 0 & & 26 & \\
\hline $3 \mathrm{H}-4,40-42$ & 66.6 & 1.965 & 92 & 69 & 43 & 57 & 0 & & 27 & \\
\hline $3 \mathrm{H}-4,60-62$ & 66.8 & 1.969 & 92 & 58 & 51 & 49 & 0 & & 27 & \\
\hline $3 \mathrm{H}-4,80-82$ & 67.0 & 1.974 & 95 & 47 & 50 & 50 & 0 & & 22 & \\
\hline $3 \mathrm{H}-4,100-102$ & 67.2 & 1.978 & 94 & 44 & 39 & 61 & 0 & & 16 & \\
\hline $3 \mathrm{H}-4,120-122$ & 67.4 & 1.982 & 95 & 47 & 37 & 63 & 0 & & 17 & \\
\hline $3 \mathrm{H}-4,140-142$ & 67.6 & 1.986 & 94 & 57 & 39 & 61 & 0 & & 21 & \\
\hline $3 \mathrm{H}-5,20-22$ & 67.9 & 1.992 & 95 & 58 & 51 & 49 & 0 & & 28 & \\
\hline $3 \mathrm{H}-5,40-42$ & 68.1 & 1.996 & 93 & 58 & 54 & 46 & 0 & & 29 & \\
\hline $3 \mathrm{H}-5,60-62$ & 68.3 & 2.000 & 94 & 60 & 49 & 51 & 0 & & 28 & \\
\hline $3 \mathrm{H}-5,80-82$ & 68.5 & 2.004 & 94 & 56 & 40 & 60 & 0 & & 21 & \\
\hline $3 \mathrm{H}-5,100-102$ & 68.7 & 2.009 & 94 & 48 & 39 & 61 & 0 & & 18 & \\
\hline $3 \mathrm{H}-5,120-122$ & 68.9 & 2.013 & 94 & 40 & 43 & 57 & 0 & & 16 & \\
\hline $3 \mathrm{H}-5,140-142$ & 69.1 & 2.017 & 94 & 52 & 48 & 52 & 0 & & 24 & \\
\hline $3 \mathrm{H}-6,20-22$ & 69.4 & 2.023 & 94 & 51 & 60 & 40 & 0 & & 29 & \\
\hline $3 \mathrm{H}-6,40-42$ & 69.6 & 2.027 & 93 & 45 & 54 & 46 & 0 & & 22 & \\
\hline $3 \mathrm{H}-6,60-62$ & 69.8 & 2.031 & 93 & 42 & 53 & 47 & 0 & & 21 & \\
\hline $3 \mathrm{H}-6,80-82$ & 70.0 & 2.035 & 91 & 57 & 52 & 48 & 0 & & 28 & \\
\hline $3 \mathrm{H}-6,100-102$ & 70.2 & 2.040 & 92 & 58 & 50 & 50 & 0 & & 27 & \\
\hline $3 \mathrm{H}-6,120-122$ & 70.4 & 2.044 & 92 & 56 & 30 & 70 & 0 & & 16 & \\
\hline $3 \mathrm{H}-6,140-142$ & 71.6 & 2.048 & 92 & 48 & 25 & 75 & 0 & & 11 & \\
\hline $3 \mathrm{H}-7,20-22$ & 70.9 & 2.054 & 94 & 53 & 42 & 48 & 0 & & 21 & \\
\hline $3 \mathrm{H}-7,40-42$ & 71.1 & 2.058 & 93 & 42 & 51 & 49 & 0 & & 20 & \\
\hline $9 \mathrm{H}-1,20-22$ & 71.6 & 2.068 & 91 & 57 & 44 & 53 & 0 & & 23 & \\
\hline $9 \mathrm{H}-1,40-42$ & 71.8 & 2.073 & 93 & 49 & 29 & 69 & 0 & & 13 & \\
\hline $9 \mathrm{H}-1,60-62$ & 72.0 & 2.077 & 95 & 45 & 33 & 66 & 0 & & 14 & \\
\hline $9 \mathrm{H}-1,80-82$ & 72.2 & 2.081 & 94 & 48 & 40 & 59 & 0 & & 18 & \\
\hline $9 \mathrm{H}-1,100-102$ & 72.4 & 2.085 & 92 & 52 & 39 & 61 & 0 & & 19 & \\
\hline $9 \mathrm{H}-1,120-122$ & 72.6 & 2.089 & 92 & 46 & 43 & 57 & 0 & & 18 & \\
\hline $9 \mathrm{H}-1,140-142$ & 72.8 & 2.093 & 94 & 36 & 24 & 76 & 0 & & 8 & \\
\hline $9 \mathrm{H}-2,20-22$ & 73.1 & 2.099 & 95 & 34 & 29 & 71 & 0 & & 9 & \\
\hline $9 \mathrm{H}-2,40-42$ & 73.3 & 2.103 & 93 & 60 & 59 & 41 & 0 & & 31 & \\
\hline $9 \mathrm{H}-2,60-62$ & 73.5 & 2.108 & 90 & 46 & 48 & 49 & 3 & & 20 & \\
\hline $9 \mathrm{H}-2,80-82$ & 73.7 & 2.112 & 90 & 51 & 40 & 56 & 0 & & 18 & \\
\hline $9 \mathrm{H}-2,100-102$ & 73.9 & 2.116 & 91 & 46 & 47 & 52 & 0 & & 20 & \\
\hline $9 \mathrm{H}-2,120-122$ & 74.1 & 2.120 & 95 & 36 & 37 & 63 & 0 & & 13 & \\
\hline $9 \mathrm{H}-2,140-142$ & 74.3 & 2.124 & 91 & 44 & 46 & 50 & 0 & & 18 & \\
\hline $9 \mathrm{H}-3,20-22$ & 74.6 & 2.130 & 94 & 37 & 29 & 69 & 0 & & 10 & \\
\hline $9 \mathrm{H}-3,40-42$ & 74.8 & 2.134 & 94 & 43 & 31 & 69 & 0 & & 13 & \\
\hline $9 \mathrm{H}-3,60-62$ & 75.0 & 2.139 & 91 & 55 & 39 & 58 & 0 & & 19 & \\
\hline $9 \mathrm{H}-3,80-82$ & 75.2 & 2.143 & 91 & 58 & 38 & 61 & 0 & & 20 & \\
\hline $9 \mathrm{H}-3,100-102$ & 75.4 & 2.147 & 92 & 53 & 33 & 67 & 0 & & 16 & \\
\hline $9 \mathrm{H}-3,120-122$ & 75.6 & 2.151 & 91 & 47 & 39 & 61 & 0 & & 17 & \\
\hline $9 \mathrm{H}-3,140-142$ & 75.8 & 2.155 & 93 & 34 & 37 & 63 & 0 & & 12 & \\
\hline $9 \mathrm{H}-4,20-22$ & 76.1 & 2.161 & 92 & 31 & 47 & 53 & 0 & & 13 & \\
\hline $9 \mathrm{H}-4,40-42$ & 76.3 & 2.165 & 92 & 31 & 44 & 55 & 0 & & 12 & \\
\hline $9 \mathrm{H}-4,60-62$ & 76.5 & 2.169 & 94 & 31 & 41 & 59 & 0 & & 12 & \\
\hline $9 \mathrm{H}-4,80-82$ & 76.7 & 2.174 & 92 & 36 & 42 & 58 & 0 & & 14 & \\
\hline $9 \mathrm{H}-4,100-102$ & 76.9 & 2.178 & 92 & 31 & 50 & 49 & 0 & & 14 & \\
\hline $9 \mathrm{H}-4,120-122$ & 77.1 & 2.182 & 90 & 52 & 59 & 40 & 0 & & 28 & \\
\hline $9 \mathrm{H}-4,140-142$ & 77.3 & 2.186 & 92 & 58 & 56 & 42 & 0 & & 30 & \\
\hline $9 \mathrm{H}-5,20-22$ & 77.6 & 2.192 & 94 & 37 & 39 & 61 & 0 & & 14 & \\
\hline $9 \mathrm{H}-5,40-42$ & 77.8 & 2.193 & 96 & 32 & 29 & 71 & 0 & & 9 & \\
\hline $9 \mathrm{H}-5,60-62$ & 78.0 & 2.200 & 95 & 36 & 35 & 65 & 0 & & 12 & \\
\hline $9 \mathrm{H}-5,80-82$ & 78.2 & 2.205 & 94 & 37 & 38 & 62 & 0 & & 13 & \\
\hline $9 \mathrm{H}-5,100-102$ & 78.4 & 2.208 & 94 & 35 & 40 & 60 & 0 & & 13 & \\
\hline $9 \mathrm{H}-5,120-122$ & 78.6 & 2.213 & 94 & 31 & 47 & 53 & 0 & & 14 & \\
\hline $9 \mathrm{H}-5,140-142$ & 78.8 & 2.217 & 95 & 29 & 41 & 59 & 0 & & 11 & \\
\hline $9 \mathrm{H}-6,20-22$ & 79.1 & 2.223 & 96 & 29 & 38 & 62 & 0 & & 10 & \\
\hline $9 \mathrm{H}-6,40-42$ & 79.3 & 2.227 & 93 & 38 & 56 & 44 & 0 & & 20 & \\
\hline $9 \mathrm{H}-6,60-62$ & 79.5 & 2.231 & 92 & 52 & 48 & 52 & 0 & & 23 & \\
\hline $9 \mathrm{H}-6,80-82$ & 79.7 & 2.235 & 92 & 49 & 50 & 48 & 0 & & 22 & \\
\hline $9 \mathrm{H}-6,100-102$ & 79.9 & 2.240 & 93 & 37 & 44 & 56 & 0 & & 15 & \\
\hline $9 \mathrm{H}-6,120-122$ & 80.1 & 2.244 & 94 & 31 & 36 & 64 & 0 & & 10 & \\
\hline $9 \mathrm{H}-6,140-142$ & 80.3 & 2.248 & 93 & 42 & 47 & 53 & 0 & & 18 & \\
\hline $9 \mathrm{H}-7,20-22$ & 80.6 & 2.254 & 93 & 34 & 51 & 49 & 0 & & 16 & \\
\hline $9 \mathrm{H}-7,40-42$ & 80.8 & 2.258 & 93 & 33 & 42 & 55 & 0 & & 13 & \\
\hline $10 \mathrm{H}-1,20-22$ & 81.3 & 2.268 & 92 & 37 & 42 & 57 & 1 & & 14 & \\
\hline $10 \mathrm{H}-1,40-42$ & 81.5 & 2.273 & 92 & 37 & 34 & 65 & 1 & & 11 & \\
\hline $10 \mathrm{H}-1,60-62$ & 81.7 & 2.277 & 92 & 29 & 40 & 60 & 0 & & 11 & \\
\hline $10 \mathrm{H}-1,80-82$ & 81.9 & 2.281 & 92 & 33 & 39 & 61 & 0 & & 12 & \\
\hline $10 \mathrm{H}-1,100-102$ & 82.1 & 2.285 & 94 & 32 & 46 & 54 & 0 & & 14 & \\
\hline $10 \mathrm{H}-1,120-122$ & 82.3 & 2.289 & 93.5 & 33 & 42 & 58 & 0 & & 13 & \\
\hline $10 \mathrm{H}-1,140-142$ & 82.5 & 2.293 & 94 & 31 & 49 & 51 & 0 & & 14 & \\
\hline $10 \mathrm{H}-2,20-22$ & 82.8 & 2.299 & 93 & 42 & 52 & 48 & 0 & & 20 & \\
\hline $10 \mathrm{H}-2,40-42$ & 83.0 & 2.304 & 93 & 46 & 36 & 61 & 3 & & 15 & \\
\hline
\end{tabular}


APPENDIX A (continued).

\begin{tabular}{|c|c|c|c|c|c|c|c|c|c|c|}
\hline \multirow[b]{2}{*}{$\begin{array}{l}\text { Core, section, } \\
\text { interval (cm) }\end{array}$} & \multirow[b]{2}{*}{$\begin{array}{l}\text { Depth } \\
\text { (m) }\end{array}$} & \multirow[b]{2}{*}{$\begin{array}{l}\text { Time } \\
(\mathrm{Ma})\end{array}$} & \multirow[b]{2}{*}{$\begin{array}{c}\text { Carbonate } \\
(\%)\end{array}$} & \multirow[b]{2}{*}{$\begin{array}{l}\text { Fine } \\
\text { fraction } \\
(\%)\end{array}$} & Carbor & te miner & ogy & & & \\
\hline & & & & & $\begin{array}{c}\text { Aragonite } \\
(\%)\end{array}$ & $\begin{array}{c}\text { Calcite } \\
(\%)\end{array}$ & $\begin{array}{l}\mathrm{Mg} \\
\text { calcite } \\
(\%)\end{array}$ & $\begin{array}{c}\delta^{18} \mathrm{O} \text { PDB } \\
\text { G. sacculifera } \\
\left(\%_{0}\right)\end{array}$ & $\begin{array}{c}\text { Aragonite } \\
\text { to total } \\
\text { sediment }(\%)\end{array}$ & $\begin{array}{c}\text { Pteropod } \\
\text { ratio }\end{array}$ \\
\hline $10 \mathrm{H}-2,60-62$ & 83.2 & 2.308 & 94 & 44 & 39 & 60 & 1 & & 16 & \\
\hline $10 \mathrm{H}-2,80-82$ & 83.4 & 2.312 & 95 & 34 & 36 & 64 & 0 & & 12 & \\
\hline $10 \mathrm{H}-2,100-102$ & 83.6 & 2.316 & 95 & 39 & 32 & 68 & 0 & & 12 & \\
\hline $10 \mathrm{H}-2,120-122$ & 83.8 & 2.320 & 94 & 37 & 50 & 50 & 0 & & 18 & \\
\hline $10 \mathrm{H}-2,140-142$ & 84.0 & 2.324 & 93 & 33 & 49 & 51 & 0 & & 15 & \\
\hline $10 \mathrm{H}-3,20-22$ & 84.3 & 2.330 & 93 & 31 & 25 & 73 & 2 & & 7 & \\
\hline $10 \mathrm{H}-3,40-42$ & 84.5 & 2.335 & 95 & 36 & 31 & 69 & 0 & & 11 & \\
\hline $10 \mathrm{H}-3,60-62$ & 84.7 & 2.339 & 95 & 34 & 39 & 61 & 0 & & 13 & \\
\hline $10 \mathrm{H}-3,80-82$ & 84.9 & 2.343 & 93 & 41 & 42 & 58 & 0 & & 16 & \\
\hline $10 \mathrm{H}-3,100-102$ & 85.1 & 2.347 & 94 & 36 & 43 & 56 & 1 & & 14 & \\
\hline $10 \mathrm{H}-3,120-122$ & 85.3 & 2.353 & 95 & 33 & 41 & 54 & 5 & & 13 & \\
\hline $10 \mathrm{H}-3,140-142$ & 85.5 & 2.363 & 94 & 39 & 46 & 54 & 0 & & 17 & \\
\hline $10 \mathrm{H}-4,20-22$ & 85.8 & 2.379 & 94 & 31 & 43 & 57 & 0 & & 13 & \\
\hline $10 \mathrm{H}-4,40-42$ & 86.0 & 2.390 & 95 & 32 & 45 & 55 & 0 & & 14 & \\
\hline $10 \mathrm{H}-4,60-62$ & 86.2 & 2.400 & 94 & 33 & 45 & 0 & & & 17 & \\
\hline $10 \mathrm{H}-4,80-82$ & 86.4 & 2.411 & 93 & 30 & 56 & 44 & 0 & & 16 & \\
\hline $10 \mathrm{H}-4,100-102$ & 86.6 & 2.422 & 95 & 28 & 55 & 43 & 2 & & 14 & \\
\hline $10 \mathrm{H}-4,120-122$ & 86.8 & 2.432 & 94 & 30 & 53 & 45 & 2 & & 15 & \\
\hline $10 \mathrm{H}-4,140-142$ & 87.0 & 2.443 & 94 & 25 & 49 & 51 & 0 & & 11 & \\
\hline $10 \mathrm{H}-5,20-22$ & 87.3 & 2.459 & 94 & 31 & 48 & 51 & 1 & & 14 & \\
\hline $10 \mathrm{H}-5,40-42$ & 87.5 & 2.469 & 93 & 30 & 41 & 56 & 3 & & 11 & \\
\hline $10 \mathrm{H}-5,60-62$ & 87.7 & 2.480 & 94 & 30 & 39 & 60 & 1 & & 11 & \\
\hline $10 \mathrm{H}-5,80-82$ & 87.9 & 2.490 & 93 & 30 & 46 & 54 & 0 & & 13 & . \\
\hline $10 \mathrm{H}-5,100-102$ & 88.1 & 2.501 & 93 & 29 & 54 & 46 & 0 & & 14 & \\
\hline $10 \mathrm{H}-5,120-122$ & 88.3 & 2.510 & 95 & 29 & 58 & 42 & 0 & & 16 & \\
\hline $10 \mathrm{H}-5,140-142$ & 88.5 & 2.520 & 94 & 27 & 64 & 36 & 0 & & 16 & \\
\hline $10 \mathrm{H}-6,20-22$ & 88.8 & 2.538 & 93 & 30 & 55 & 45 & 0 & & 15 & \\
\hline $10 \mathrm{H}-6,40-42$ & 89.0 & 2.549 & 93 & 29 & 61 & 39 & 0 & & 17 & \\
\hline $10 \mathrm{H}-6,60-62$ & 89.2 & 2.559 & 93 & 32 & 47 & 52 & 1 & & 14 & \\
\hline $10 \mathrm{H}-6,80-82$ & 89.4 & 2.570 & 93 & 33 & 35 & 65 & 0 & & 11 & \\
\hline $10 \mathrm{H}-6,100-102$ & 89.6 & 2.580 & 94 & 32 & 41 & 59 & 0 & & 12 & \\
\hline $10 \mathrm{H}-6,120-122$ & 89.8 & 2.594 & 94 & 29 & 42 & 58 & 0 & & 12 & \\
\hline $10 \mathrm{H}-6,140-142$ & 90.0 & 2.602 & 92 & 35 & 39 & 61 & 0 & & 13 & \\
\hline $10 \mathrm{H}-7,20-22$ & 90.3 & 2.618 & 92 & 30 & 39 & 61 & 0 & & 11 & \\
\hline $10 \mathrm{H}-7,40-42$ & 90.5 & 2.628 & 95 & 26 & 29 & 71 & 0 & & 7 & \\
\hline $11 \mathrm{H}-1,20-22$ & 90.9 & 2.649 & 95 & 29 & 24 & 76 & 0 & & 7 & \\
\hline $11 \mathrm{H}-1,40-42$ & 91.1 & 2.660 & 94 & 46 & 21 & 79 & 0 & & 9 & \\
\hline $11 \mathrm{H}-1,60-62$ & 91.3 & 2.671 & 95 & 45 & 30 & 70 & 0 & & 13 & \\
\hline $11 \mathrm{H}-1,80-82$ & 91.5 & 2.681 & 96 & 41 & 33 & 67 & 0 & & 13 & \\
\hline $11 \mathrm{H}-1,100-102$ & 91.7 & 2.692 & 93 & 36 & 39 & 61 & 0 & & 13 & \\
\hline $11 \mathrm{H}-1,120-122$ & 91.9 & 2.703 & 93 & 36 & 41 & 59 & 0 & & 14 & \\
\hline $11 \mathrm{H}-1,140-142$ & 92.1 & 2.713 & 93 & 39 & 42 & 58 & 0 & & 15 & \\
\hline $11 \mathrm{H}-2,20-22$ & 92.4 & 2.729 & 93 & 40 & 38 & 62 & 0 & & 14 & \\
\hline $11 \mathrm{H}-2,40-42$ & 92.6 & 2.740 & 92 & 42 & 36 & 64 & 0 & & 14 & \\
\hline $11 \mathrm{H}-2,60-62$ & 92.8 & 2.750 & 93 & 44 & 30 & 70 & 0 & & 12 & \\
\hline $11 \mathrm{H}-2,80-82$ & 93.0 & 2.761 & 93 & 51 & 44 & 56 & 0 & & 21 & \\
\hline $11 \mathrm{H}-2,100-102$ & 93.2 & 2.771 & 94 & 51 & 45 & 55 & 0 & & 22 & \\
\hline $11 \mathrm{H}-2,120-122$ & 93.4 & 2.782 & 94 & 40 & 46 & 54 & 0 & & 18 & \\
\hline $11 \mathrm{H}-2,140-142$ & 93.6 & 2.793 & 95 & 39 & 41 & 59 & 0 & & 15 & \\
\hline $11 \mathrm{H}-3,20-22$ & 93.9 & 2.809 & 94 & 38 & 36 & 64 & 0 & & 13 & \\
\hline $11 \mathrm{H}-3,40-42$ & 94.1 & 2.819 & 95 & 35 & 31 & 69 & 0 & & 10 & \\
\hline $11 \mathrm{H}-3,60-62$ & 94.3 & 2.830 & 95 & 35 & 30 & 70 & 0 & & 10 & \\
\hline $11 \mathrm{H}-3,80-82$ & 94.5 & 2.840 & 94 & 36 & 36 & 64 & 0 & & 12 & \\
\hline $11 \mathrm{H}-3,100-102$ & 94.7 & 2.851 & 95 & 39 & 40 & 60 & 0 & & 15 & \\
\hline $11 \mathrm{H}-3,120-122$ & 94.9 & 2.862 & 95 & 37 & 40 & 60 & 0 & & 14 & \\
\hline $11 \mathrm{H}-3,140-142$ & 95.1 & 2.872 & 96 & 39 & 40 & 60 & 0 & & 15 & \\
\hline $11 \mathrm{H}-4,20-22$ & 95.4 & 2.888 & 96 & 36 & 43 & 57 & 0 & & 15 & \\
\hline $11 \mathrm{H}-4,40-42$ & 95.6 & 2.899 & 94 & 40 & 45 & 55 & 0 & & 17 & \\
\hline $11 \mathrm{H}-4,60-62$ & 95.8 & 2.909 & 94 & 45 & 48 & 52 & 0 & & 20 & \\
\hline $11 \mathrm{H}-4,80-82$ & 96.0 & 2.920 & 94 & 35 & 56 & 44 & 0 & & 19 & \\
\hline $11 \mathrm{H}-4,100-102$ & 96.2 & 2.930 & 95 & 38 & 56 & 44 & 0 & & 20 & \\
\hline $11 \mathrm{H}-4,120-122$ & 96.4 & 2.941 & 95 & 38 & 54 & 46 & 0 & & 19 & \\
\hline $11 \mathrm{H}-4,140-142$ & 96.6 & 2.952 & 93 & 38 & 50 & 50 & 0 & & 17 & \\
\hline $11 \mathrm{H}-5,20-22$ & 96.9 & 2.967 & 91 & 40 & 40 & 60 & 0 & & 14 & \\
\hline $11 \mathrm{H}-5,40-42$ & 97.1 & 2.978 & 93 & 39 & 38 & 62 & 0 & & 14 & \\
\hline $11 \mathrm{H}-5,60-62$ & 97.3 & 2.989 & 94 & 44 & 37 & 63 & 0 & & 15 & \\
\hline $11 \mathrm{H}-5,80-82$ & 97.5 & 2.999 & 93 & 57 & 36 & 64 & 0 & & 19 & \\
\hline $11 \mathrm{H}-5,100-102$ & 97.7 & 3.010 & 95 & 31 & 25 & 75 & 0 & & 7 & \\
\hline $11 \mathrm{H}-5,120-122$ & 97.9 & 3.020 & 92 & 52 & 37 & 63 & 0 & & 18 & \\
\hline $11 \mathrm{H}-5,140-142$ & 98.1 & 3.031 & 93 & 44 & 40 & 60 & 0 & & 16 & \\
\hline $11 \mathrm{H}-6,20-22$ & 98.4 & 3.047 & 94 & 39 & 28 & 72 & 0 & & 10 & \\
\hline $11 \mathrm{H}-6,40-42$ & 98.6 & 3.058 & 91 & 53 & 52 & 48 & 0 & & 25 & \\
\hline $11 \mathrm{H}-6,60-62$ & 98.8 & 3.068 & 94 & 45 & 46 & 54 & 0 & & 19 & \\
\hline $11 \mathrm{H}-6,80-82$ & 99.0 & 3.079 & 96 & 30 & 42 & 58 & 0 & & 12 & \\
\hline $11 \mathrm{H}-6,100-102$ & 99.2 & 3.089 & 95 & 33 & 33 & 67 & 0 & & 10 & \\
\hline
\end{tabular}


APPENDIX A (continued).

\begin{tabular}{|c|c|c|c|c|c|c|c|c|c|c|}
\hline \multirow[b]{2}{*}{$\begin{array}{l}\text { Core, section, } \\
\text { interval }(\mathrm{cm})\end{array}$} & \multirow[b]{2}{*}{$\begin{array}{l}\text { Depth } \\
\text { (m) }\end{array}$} & \multirow[b]{2}{*}{$\begin{array}{l}\text { Time } \\
\text { (Ma) }\end{array}$} & \multirow[b]{2}{*}{$\begin{array}{c}\text { Carbonate } \\
(\%)\end{array}$} & \multirow[b]{2}{*}{$\begin{array}{l}\text { Fine } \\
\text { fraction } \\
(\%)\end{array}$} & \multicolumn{3}{|c|}{ Carbonate mineralogy } & \multirow[b]{2}{*}{$\begin{array}{c}\delta^{18} \mathrm{O} \text { PDB } \\
\text { G. sacculifera } \\
\left(\%{ }^{2}\right)\end{array}$} & \multirow[b]{2}{*}{$\begin{array}{c}\text { Aragonite } \\
\text { to total } \\
\text { sediment }(\%)\end{array}$} & \multirow[b]{2}{*}{$\begin{array}{l}\text { Pteropoc } \\
\text { ratio }\end{array}$} \\
\hline & & & & & $\begin{array}{c}\text { Aragonite } \\
(\%)\end{array}$ & $\begin{array}{l}\text { Calcite } \\
(\%)\end{array}$ & $\begin{array}{l}\text { Mg } \\
\text { calcite } \\
(\%)\end{array}$ & & & \\
\hline $11 \mathrm{H}-6,120-122$ & 99.4 & 3.100 & 93 & 45 & 36 & 64 & 0 & & 15 & \\
\hline $11 \mathrm{H}-6,140-142$ & 99.6 & 3.111 & 94 & 59 & 37 & 63 & 0 & & 20 & \\
\hline $11 \mathrm{H}-7,20-22$ & 99.9 & 3.127 & 95 & 32 & 30 & 70 & 0 & & 9 & \\
\hline $11 \mathrm{H}-7,40-42$ & 100.1 & 3.137 & 95 & 41 & 25 & 75 & 0 & & 10 & \\
\hline $11 \mathrm{H}-7,60-62$ & 100.3 & 3.148 & 93 & 59 & 36 & 64 & 0 & & 20 & \\
\hline $12 \mathrm{H}-1,20-22$ & 100.5 & 3.158 & 92 & 54 & 34 & 66 & 0 & & 17 & \\
\hline $12 \mathrm{H}-1,40-42$ & 100.7 & 3.169 & 95 & 45 & 37 & 63 & 0 & & 16 & \\
\hline $12 \mathrm{H}-1,60-62$ & 100.9 & 3.180 & 95 & 38 & 30 & 70 & 0 & & 11 & \\
\hline $12 \mathrm{H}-1,80-82$ & 101.1 & 3.190 & 94 & 45 & 29 & 71 & 0 & & 12 & \\
\hline $12 \mathrm{H}-1,100-102$ & 101.3 & 3.201 & 95 & 40 & 38 & 62 & 0 & & 14 & \\
\hline $12 \mathrm{H}-1,120-122$ & 101.5 & 3.211 & 94 & 36 & 29 & 71 & 0 & & 10 & \\
\hline $12 \mathrm{H}-1,140-142$ & 101.7 & 3.222 & 93 & 45 & 23 & 77 & 0 & & 10 & \\
\hline $12 \mathrm{H}-2,20-22$ & 102.0 & 3.238 & 93 & 37 & 36 & 64 & 0 & & 12 & \\
\hline $12 \mathrm{H}-2,40-42$ & 102.2 & 3.249 & 92 & 39 & 35 & 65 & 0 & & 13 & \\
\hline $12 \mathrm{H}-2,60-62$ & 102.4 & 3.259 & 94 & 38 & 38 & 62 & 0 & & 13 & \\
\hline $12 \mathrm{H}-2,80-82$ & 102.6 & 3.270 & 95 & 43 & 22 & 78 & 0 & & 9 & \\
\hline $12 \mathrm{H}-2,100-102$ & 102.8 & 3.280 & 95 & 41 & 25 & 75 & 0 & & 10 & \\
\hline $12 \mathrm{H}-2,120-122$ & 103.0 & 3.291 & 93 & 51 & 28 & 72 & 0 & & 13 & \\
\hline $12 \mathrm{H}-2,140-142$ & 103.2 & 3.302 & 93 & 36 & 20 & 80 & 0 & & 7 & \\
\hline $12 \mathrm{H}-3,20-22$ & 103.5 & 3.318 & 93 & 40 & 24 & 76 & 0 & & 9 & \\
\hline $12 \mathrm{H}-3,40-42$ & 103.7 & 3.328 & 93 & 40 & 23 & 77 & 0 & & 8 & \\
\hline $12 \mathrm{H}-3,60-62$ & 103.9 & 3.339 & 91 & 39 & 32 & 68 & 0 & & 11 & \\
\hline $12 \mathrm{H}-3,80-82$ & 104.1 & 3.349 & 94 & 49 & 24 & 76 & 0 & & 11 & \\
\hline $12 \mathrm{H}-3,100-102$ & 104.3 & 3.360 & 93 & 47 & 20 & 80 & 0 & & 9 & \\
\hline $12 \mathrm{H}-3,120-122$ & 104.5 & 3.370 & 94 & 38 & 23 & 77 & 0 & & 8 & \\
\hline $12 \mathrm{H}-3,140-142$ & 104.7 & 3.381 & 94 & 45 & 20 & 80 & 0 & & 8 & \\
\hline $12 \mathrm{H}-4,20-22$ & 105.0 & 3.397 & 95 & 39 & 16 & 84 & 0 & & 6 & \\
\hline $12 \mathrm{H}-4,40-42$ & 105.2 & 3.408 & 95 & 39 & 21 & 79 & 0 & & 8 & \\
\hline $12 \mathrm{H}-4,60-62$ & 105.4 & 3.418 & 96 & 37 & 25 & 75 & 0 & & 9 & \\
\hline $12 \mathrm{H}-4,80-82$ & 105.6 & 3.429 & 94 & 42 & 28 & 72 & 0 & & 11 & \\
\hline $12 \mathrm{H}-4,100-102$ & 105.8 & 3.439 & 95 & 45 & 23 & 77 & 0 & & 10 & \\
\hline $12 \mathrm{H}-4,120-122$ & 106.0 & 3.450 & 95 & 42 & 28 & 72 & 0 & & 11 & \\
\hline $12 \mathrm{H}-4,140-142$ & 106.2 & 3.460 & 95 & 49 & 22 & 78 & 0 & & 10 & \\
\hline $12 \mathrm{H}-5,20-22$ & 106.5 & 3.471 & 93 & 42 & 29 & 71 & 0 & & 11 & \\
\hline $12 \mathrm{H}-5,40-42$ & 106.7 & 3.482 & 94 & 39 & 25 & 75 & 0 & & 9 & \\
\hline $12 \mathrm{H}-5,60-62$ & 106.9 & 3.491 & 94 & 40 & 23 & 77 & 0 & & 9 & \\
\hline $12 \mathrm{H}-5,80-82$ & 107.1 & 3.501 & 95 & 44 & 21 & 79 & 0 & & 9 & \\
\hline $12 \mathrm{H}-5,100-102$ & 107.3 & 3.511 & 94 & 50 & 15 & 85 & 0 & & 7 & \\
\hline $12 \mathrm{H}-5,120-122$ & 107.5 & 3.520 & 94 & 42 & 18 & 82 & 0 & & 7 & \\
\hline $12 \mathrm{H}-5,140-142$ & 107.7 & 3.531 & 95 & 53 & 20 & 80 & 0 & & 10 & \\
\hline $12 \mathrm{H}-6,20-22$ & 107.9 & 3.542 & 94 & 46 & 29 & 71 & 0 & & 12 & \\
\hline $12 \mathrm{H}-6,40-42$ & 108.2 & 3.551 & 92 & 44 & 20 & 80 & 0 & & 8 & \\
\hline $12 \mathrm{H}-6,60-62$ & 108.4 & 3.563 & 95 & 41 & 9 & 91 & 0 & & 4 & \\
\hline $12 \mathrm{H}-6,80-82$ & 108.6 & 3.572 & 94 & 49 & 19 & 81 & 0 & & 9 & \\
\hline $12 \mathrm{H}-6,100-102$ & 108.8 & 3.581 & 94 & 48 & 22 & 78 & 0 & & 10 & \\
\hline $12 \mathrm{H}-6,12 \mathrm{G}-122$ & 109.0 & 3.593 & 93 & 58 & 29 & 71 & 0 & & 16 & \\
\hline $12 \mathrm{H}-6,140-142$ & 109.2 & 3.602 & 93 & 55 & 29 & 71 & 0 & & 15 & \\
\hline $12 \mathrm{H}-7,20-22$ & 109.5 & 3.613 & 94 & 41 & 24 & 76 & 0 & & 9 & \\
\hline $12 \mathrm{H}-7,40-42$ & 109.7 & 3.623 & 94 & 58 & 19 & 81 & 0 & & 10 & \\
\hline
\end{tabular}


APPENDIX B

Carbonate Mineralogy and Oxygen Isotope Data for Sediment Samples from Hole 714A.

\begin{tabular}{|c|c|c|c|c|c|c|c|c|c|}
\hline \multirow[b]{2}{*}{$\begin{array}{l}\text { Core, section, } \\
\text { interval }(\mathrm{cm})\end{array}$} & \multirow[b]{2}{*}{$\begin{array}{l}\text { Depth } \\
\text { (m) }\end{array}$} & \multirow[b]{2}{*}{$\begin{array}{l}\text { Time } \\
\text { (Ma) }\end{array}$} & \multirow[b]{2}{*}{$\begin{array}{c}\text { Carbonate } \\
(\%)\end{array}$} & \multirow[b]{2}{*}{$\begin{array}{l}\text { Fine } \\
\text { fraction } \\
(\%)\end{array}$} & \multicolumn{3}{|c|}{ Carbonate mineralogy } & \multirow[b]{2}{*}{$\begin{array}{c}\delta^{18} \mathrm{O} \text { PDB } \\
\text { G. sacculifera } \\
\left(\% \%_{0}\right)\end{array}$} & \\
\hline & & & & & $\begin{array}{l}\text { Aragonite } \\
(\%)\end{array}$ & $\begin{array}{c}\text { Calcite } \\
(\%)\end{array}$ & $\begin{array}{l}\mathrm{Mg} \\
\text { calcite } \\
(\%)\end{array}$ & & $\begin{array}{c}\text { Aragonite } \\
\text { to total } \\
\text { sediment }(\%)\end{array}$ \\
\hline $1 \mathrm{H}-1,5-7$ & 0.05 & 0.001 & 77 & 65 & 41 & 59 & 0 & & 30 \\
\hline $1 \mathrm{H}-1,15-17$ & 0.15 & 0.003 & 78 & 50 & 40 & 60 & 0 & -2.01 & 23 \\
\hline $1 \mathrm{H}-1,25-27$ & 0.25 & 0.005 & 78 & 51 & 35 & 65 & 0 & & 26 \\
\hline $1 \mathrm{H}-1,35-37$ & 0.35 & 0.006 & 75 & 56 & 37 & 63 & 0 & -1.63 & 27 \\
\hline $1 \mathrm{H}-1,45-47$ & 0.45 & 0.008 & 75 & 53 & 37 & 63 & 0 & & 25 \\
\hline $1 \mathrm{H}-1,55-57$ & 0.55 & 0.010 & 70 & 53 & 51 & 49 & 0 & -1.00 & 18 \\
\hline $1 \mathrm{H}-1,65-67$ & 0.65 & 0.012 & 65 & 61 & 61 & 39 & 0 & & 15 \\
\hline $1 \mathrm{H}-1,75-77$ & 0.75 & 0.014 & 60 & 34 & 70 & 30 & 0 & -0.62 & 6 \\
\hline $1 \mathrm{H}-1,85-87$ & 0.85 & 0.015 & 60 & 44 & 76 & 24 & 0 & -0.86 & 6 \\
\hline $1 \mathrm{H}-1,95-97$ & 0.95 & 0.016 & 56 & 44 & 83 & 17 & 0 & -0.30 & 4 \\
\hline $1 \mathrm{H}-1,105-107$ & 1.05 & 0.018 & 53 & 50 & 88 & 12 & 0 & & 3 \\
\hline $1 \mathrm{H}-1,115-117$ & 1.15 & 0.020 & 55 & 55 & 87 & 13 & 0 & -0.74 & 4 \\
\hline $1 \mathrm{H}-1,125-127$ & 1.25 & 0.021 & 58 & 42 & 82 & 18 & 0 & & 4 \\
\hline $1 \mathrm{H}-1,135-137$ & 1.35 & 0.022 & 59 & 47 & 77 & 23 & 0 & -0.42 & 6 \\
\hline $1 \mathrm{H}-2,5-7$ & 1.55 & 0.029 & 59 & 44 & 79 & 21 & 0 & -0.64 & 6 \\
\hline $1 \mathrm{H}-2,15-17$ & 1.65 & 0.033 & 61 & 42 & 85 & 15 & 0 & & 4 \\
\hline $1 \mathrm{H}-2,25-27$ & 1.75 & 0.038 & 60 & 47 & 90 & 10 & 0 & -0.65 & 3 \\
\hline $1 \mathrm{H}-2,35-37$ & 1.85 & 0.043 & 60 & 46 & & & 0 & & \\
\hline $1 \mathrm{H}-2,45-47$ & 1.95 & 0.047 & 61 & 38 & 79 & 21 & 0 & -0.88 & 5 \\
\hline $1 \mathrm{H}-2,55-57$ & 2.05 & 0.052 & 58 & 44 & 80 & 20 & 0 & & 5 \\
\hline $1 \mathrm{H}-2,65-67$ & 2.15 & 0.057 & 57 & 56 & 65 & 35 & 0 & -1.00 & 11 \\
\hline $1 \mathrm{H}-2,75-77$ & 2.25 & 0.061 & 49 & 56 & 75 & 25 & 0 & -0.68 & 7 \\
\hline $1 \mathrm{H}-2,85-87$ & 2.35 & 0.066 & 50 & 50 & 80 & 20 & 0 & -0.40 & 5 \\
\hline $1 \mathrm{H}-2,95-97$ & 2.45 & 0.071 & 51 & 54 & 83 & 17 & 0 & & 5 \\
\hline $1 \mathrm{H}-2,105-107$ & 2.55 & 0.074 & 41 & 57 & 100 & 0 & 0 & -1.16 & 0 \\
\hline $2 \mathrm{H}-1,5-7$ & 2.85 & 0.082 & 75 & 66 & 58 & 42 & 0 & -1.29 & 21 \\
\hline $2 \mathrm{H}-1,15-17$ & 2.95 & 0.085 & 74 & 67 & 62 & 38 & 0 & & 19 \\
\hline $2 \mathrm{H}-1,25-27$ & 3.05 & 0.088 & 75 & 68 & 60 & 40 & 0 & -1.39 & 20 \\
\hline $2 \mathrm{H}-1,35-37$ & 3.15 & 0.090 & 74 & 67 & 62 & 38 & 0 & & 19 \\
\hline $2 \mathrm{H}-1,45-47$ & 3.25 & 0.093 & 76 & 63 & 47 & 53 & 0 & -1.80 & 25 \\
\hline $2 \mathrm{H}-1,55-57$ & 3.35 & 0.096 & 74 & 61 & 44 & 56 & 0 & & 25 \\
\hline $2 \mathrm{H}-1,65-67$ & 3.45 & 0.099 & 74 & 57 & & & 0 & -1.71 & \\
\hline $2 \mathrm{H}-1,75-77$ & 3.55 & 0.102 & 69 & 62 & 49 & 51 & 0 & & 22 \\
\hline $2 \mathrm{H}-1,85-87$ & 3.65 & 0.104 & 70 & 55 & 56 & 44 & 0 & -1.41 & 17 \\
\hline $2 \mathrm{H}-1,95-97$ & 3.75 & 0.107 & 74 & 65 & 61 & 39 & 0 & & 19 \\
\hline $2 \mathrm{H}-1,105-107$ & 3.85 & 0.110 & 76 & 62 & 65 & 35 & 0 & -1.40 & 17 \\
\hline $2 \mathrm{H}-1,115-117$ & 3.95 & 0.113 & 77 & 66 & 48 & 52 & 0 & & 26 \\
\hline $2 \mathrm{H}-1,125-127$ & 4.05 & 0.115 & 76 & 62 & 45 & 55 & 0 & -1.93 & 26 \\
\hline $2 \mathrm{H}-1,135-137$ & 4.15 & 0.118 & 74 & 65 & 43 & 57 & 0 & & 27 \\
\hline $2 \mathrm{H}-1,145-147$ & 4.25 & 0.121 & 73 & 59 & 36 & 64 & 0 & -2.38 & 28 \\
\hline $2 \mathrm{H}-2,5-7$ & 4.35 & 0.124 & 75 & 55 & 35 & 65 & 0 & & 27 \\
\hline $2 \mathrm{H}-2,15-17$ & 4.45 & 0.127 & 67 & 68 & 33 & 67 & 0 & -1.65 & 31 \\
\hline $2 \mathrm{H}-2,25-27$ & 4.55 & 0.136 & 65 & 57 & 38 & 62 & 0 & & 23 \\
\hline $2 \mathrm{H}-2,35-37$ & 4.65 & 0.139 & 65 & 69 & 51 & 49 & 0 & -0.95 & 22 \\
\hline $2 \mathrm{H}-2,45-47$ & 4.75 & 0.142 & 66 & 58 & 61 & 39 & 0 & & 15 \\
\hline $2 \mathrm{H}-2,55-57$ & 4.85 & 0.145 & 64 & 49 & 65 & 35 & 0 & -0.83 & 11 \\
\hline $2 \mathrm{H}-2,65-67$ & 4.95 & 0.148 & 64 & 49 & 70 & 30 & 0 & -0.61 & 9 \\
\hline $2 \mathrm{H}-2,75-77$ & 5.05 & 0.151 & 63 & 50 & 75 & 25 & 0 & & 8 \\
\hline $2 \mathrm{H}-2,85-87$ & 5.15 & 0.154 & 62 & 53 & 79 & 21 & 0 & -0.50 & 7 \\
\hline $2 \mathrm{H}-2,95-97$ & 5.25 & 0.157 & 60 & 57 & 78 & 22 & 0 & & 7 \\
\hline $2 \mathrm{H}-2,105-107$ & 5.35 & 0.160 & 58 & 54 & 63 & 37 & 0 & -1.03 & 12 \\
\hline $2 \mathrm{H}-2,115-117$ & 5.45 & 0.163 & 62 & 65 & 59 & 41 & 0 & & 16 \\
\hline $2 \mathrm{H}-2,125-127$ & 5.55 & 0.166 & 59 & 38 & 59 & 41 & 0 & -0.88 & 9 \\
\hline $2 \mathrm{H}-2,135-137$ & 5.65 & 0.169 & 55 & 35 & 49 & 51 & 0 & & 10 \\
\hline $2 \mathrm{H}-2,145-147$ & 5.75 & 0.172 & 48 & 38 & 64 & 36 & 0 & -0.85 & 7 \\
\hline $2 \mathrm{H}-3,5-7$ & 5.85 & 0.175 & 55 & 44 & 64 & 36 & 0 & -0.73 & 9 \\
\hline $2 \mathrm{H}-3,15-17$ & 5.95 & 0.178 & 57 & 43 & 71 & 29 & 0 & & 7 \\
\hline $2 \mathrm{H}-3,25-27$ & 6.05 & 0.181 & 56 & 44 & 68 & 32 & 0 & -0.97 & 8 \\
\hline $2 \mathrm{H}-3,35-37$ & 6.15 & 0.184 & 61 & 47 & 68 & 32 & 0 & & 9 \\
\hline $2 \mathrm{H}-3,45-47$ & 6.25 & 0.187 & 59 & 47 & 79 & 21 & 0 & -0.95 & 6 \\
\hline $2 \mathrm{H}-3,55-57$ & 6.35 & 0.189 & 52 & 42 & 84 & 16 & 0 & & 4 \\
\hline $2 \mathrm{H}-3,65-67$ & 6.45 & 0.191 & 63 & 50 & 83 & 17 & 0 & -1.24 & 5 \\
\hline $2 \mathrm{H}-3,75-77$ & 6.55 & 0.193 & 64 & 53 & 64 & 36 & 0 & & 12 \\
\hline $2 \mathrm{H}-3,85-87$ & 6.65 & 0.195 & 75 & 42 & 44 & 56 & 0 & -1.79 & 18 \\
\hline $2 \mathrm{H}-3,95-97$ & 6.75 & 0.197 & 79 & 31 & 62 & 38 & 0 & & 9 \\
\hline $2 \mathrm{H}-3,105-107$ & 6.85 & 0.199 & 78 & 30 & 47 & 53 & 0 & -1.40 & 12 \\
\hline $2 \mathrm{H}-3,115-117$ & 6.95 & 0.201 & 81 & 29 & 43 & 57 & 0 & & 13 \\
\hline $2 \mathrm{H}-3,125-127$ & 7.05 & 0.203 & 78 & 37 & 37 & 63 & 0 & -1.79 & 18 \\
\hline $2 \mathrm{H}-3,135-137$ & 7.15 & 0.205 & 80 & 33 & 38 & 62 & 0 & & 16 \\
\hline $2 \mathrm{H}-3,145-147$ & 7.25 & 0.207 & 79 & 35 & 36 & 64 & 0 & -1.71 & 18 \\
\hline $2 \mathrm{H}-4,5-7$ & 7.35 & 0.209 & 74 & 41 & 36 & 64 & 0 & -1.26 & 19 \\
\hline $2 \mathrm{H}-4,15-17$ & 7.45 & 0.211 & 70 & 37 & 45 & 55 & 0 & & 14 \\
\hline $2 \mathrm{H}-4,25-27$ & 7.55 & 0.213 & 65 & 38 & 53 & 47 & 0 & -1.15 & 11 \\
\hline
\end{tabular}


APPENDIX B (continued).

\begin{tabular}{|c|c|c|c|c|c|c|c|c|c|}
\hline \multirow[b]{2}{*}{$\begin{array}{l}\text { Core, section, } \\
\text { interval }(\mathrm{cm})\end{array}$} & \multirow[b]{2}{*}{$\begin{array}{l}\text { Depth } \\
\text { (m) }\end{array}$} & \multirow[b]{2}{*}{$\begin{array}{l}\text { Time } \\
\text { (Ma) }\end{array}$} & \multirow[b]{2}{*}{$\begin{array}{c}\text { Carbonate } \\
(\%)\end{array}$} & \multirow[b]{2}{*}{$\begin{array}{c}\text { Fine } \\
\text { fraction } \\
(\%)\end{array}$} & Carbona & mineral & & & \\
\hline & & & & & $\begin{array}{l}\text { Aragonite } \\
(\%)\end{array}$ & $\begin{array}{c}\text { Calcite } \\
(\%)\end{array}$ & $\begin{array}{c}\mathrm{Mg} \\
\text { calcite } \\
(\%)\end{array}$ & $\begin{array}{c}\delta^{18} \mathrm{O} \text { PDB } \\
\text { G. sacculifera } \\
\left(\% \%_{0}\right)\end{array}$ & $\begin{array}{c}\text { Aragonite } \\
\text { to total } \\
\text { sediment }(\%)\end{array}$ \\
\hline $2 \mathrm{H}-4,35-37$ & 7.65 & 0.215 & 63 & 44 & 58 & 42 & 0 & & 12 \\
\hline $2 \mathrm{H}-4,45-47$ & 7.75 & 0.217 & 60 & 40 & 70 & 30 & 0 & -1.14 & 7 \\
\hline $2 \mathrm{H}-4,55-57$ & 7.85 & 0.219 & 58 & 39 & 71 & 29 & 0 & & 6 \\
\hline $2 \mathrm{H}-4,65-67$ & 7.95 & 0.221 & 62 & 46 & 78 & 22 & 0 & -1.22 & 6 \\
\hline $2 \mathrm{H}-4,75-77$ & 8.05 & 0.223 & 64 & 42 & 85 & 15 & 0 & & 4 \\
\hline $2 \mathrm{H}-4,85-87$ & 8.15 & 0.225 & 67 & 45 & 70 & 30 & 0 & -0.96 & 9 \\
\hline $2 \mathrm{H}-4,95-97$ & 8.25 & 0.227 & 68 & 52 & 70 & 30 & 0 & & 11 \\
\hline $2 \mathrm{H}-4,105-107$ & 8.35 & 0.229 & 71 & 38 & 61 & 39 & 0 & -0.99 & 10 \\
\hline $2 \mathrm{H}-4,115-117$ & 8.45 & 0.231 & 75 & 34 & 63 & 37 & 0 & & 9 \\
\hline $2 \mathrm{H}-4,125-127$ & 8.55 & 0.233 & 76 & 36 & 55 & 45 & 0 & -0.99 & 12 \\
\hline $2 \mathrm{H}-4,135-137$ & 8.65 & 0.235 & 80 & 30 & 51 & 49 & 0 & & 12 \\
\hline $2 \mathrm{H}-5,5-7$ & 8.85 & 0.239 & 80 & 35 & 49 & 51 & 0 & -1.28 & 14 \\
\hline $2 \mathrm{H}-5,15-17$ & 8.95 & 0.241 & 83 & 35 & 48 & 52 & 0 & & 15 \\
\hline $2 \mathrm{H}-5,25-27$ & 9.05 & 0.243 & 82 & 40 & 51 & 49 & 0 & -1.44 & 16 \\
\hline $2 \mathrm{H}-5,35-37$ & 9.15 & 0.245 & 69 & 49 & 78 & 22 & 0 & & 7 \\
\hline $2 \mathrm{H}-5,45-47$ & 9.25 & 0.250 & 72 & 45 & 79 & 21 & 0 & -0.76 & 7 \\
\hline $2 \mathrm{H}-5,55-57$ & 9.35 & 0.254 & 72 & 44 & 80 & 20 & 0 & & 6 \\
\hline $2 \mathrm{H}-5,65-67$ & 9.45 & 0.259 & 70 & 43 & 79 & 21 & 0 & -0.84 & 6 \\
\hline $2 \mathrm{H}-5,75-77$ & 9.55 & 0.264 & 65 & 44 & 80 & 20 & 0 & & 6 \\
\hline $2 \mathrm{H}-5,85-87$ & 9.65 & 0.268 & 65 & 39 & 72 & 28 & 0 & -0.84 & 7 \\
\hline $2 \mathrm{H}-5,95-97$ & 9.75 & 0.273 & 66 & 46 & 77 & 23 & 0 & & 7 \\
\hline $2 \mathrm{H}-5,105-107$ & 9.85 & 0.277 & 62 & 42 & 69 & 31 & 0 & -0.64 & 8 \\
\hline $2 \mathrm{H}-5,115-117$ & 9.95 & 0.282 & 63 & 36 & 68 & 32 & 0 & & 7 \\
\hline $2 \mathrm{H}-5,125-127$ & 10.05 & 0.287 & 58 & & 69 & 31 & 0 & -0.62 & \\
\hline $2 \mathrm{H}-5,135-137$ & 10.15 & 0.291 & 59 & 41 & 71 & 29 & 0 & & 7 \\
\hline $2 \mathrm{H}-5,145-147$ & 10.25 & 0.296 & 56 & 43 & 81 & 19 & 0 & -0.69 & 5 \\
\hline $2 \mathrm{H}-6,5-7$ & 10.35 & 0.301 & 60 & 50 & 84 & 16 & 0 & -1.10 & 5 \\
\hline $2 \mathrm{H}-6,15-17$ & 10.45 & 0.304 & 63 & 42 & 82 & 18 & 0 & & 5 \\
\hline $2 \mathrm{H}-6,25-27$ & 10.55 & 0.306 & 69 & 35 & 75 & 25 & 0 & -1.15 & 6 \\
\hline $2 \mathrm{H}-6,35-37$ & 10.65 & 0.308 & 71 & 43 & 62 & 38 & 0 & & 12 \\
\hline $2 \mathrm{H}-6,45-47$ & 10.75 & 0.309 & 74 & 36 & 63 & 37 & 0 & -1.32 & 10 \\
\hline $2 \mathrm{H}-6,55-57$ & 10.85 & 0.311 & 78 & 40 & 55 & 45 & 0 & & 14 \\
\hline $2 \mathrm{H}-6,65-67$ & 10.95 & 0.313 & 78 & 40 & 49 & 51 & 0 & -1.64 & 16 \\
\hline $2 \mathrm{H}-6,75-77$ & 11.05 & 0.315 & 73 & 33 & 50 & 50 & 0 & & 12 \\
\hline $2 \mathrm{H}-6,85-87$ & 11.15 & 0.317 & 73 & 28 & 76 & 24 & 0 & -0.87 & 5 \\
\hline $2 \mathrm{H}-6,95-97$ & 11.25 & 0.319 & 83 & 73 & 70 & 30 & 0 & & 18 \\
\hline $2 \mathrm{H}-6,105-107$ & 11.35 & 0.321 & 77 & 62 & 63 & 37 & 0 & -1.19 & 18 \\
\hline $2 \mathrm{H}-6,115-117$ & 11.45 & 0.322 & 78 & 52 & 66 & 34 & 0 & & 14 \\
\hline $2 \mathrm{H}-6,125-127$ & 11.55 & 0.324 & 77 & 53 & 64 & 36 & 0 & -1.67 & 15 \\
\hline $2 \mathrm{H}-6,135-137$ & 11.65 & 0.326 & 76 & 51 & 61 & 39 & 0 & & 15 \\
\hline $2 \mathrm{H}-6,145-147$ & 11.75 & 0.328 & 84 & 64 & 68 & 32 & 0 & -1.06 & 17 \\
\hline $2 \mathrm{H}-7,5-7$ & 11.85 & 0.330 & 87 & 71 & 67 & 33 & 0 & -1.49 & 20 \\
\hline $2 \mathrm{H}-7,15-17$ & 11.95 & 0.332 & 88 & 68 & 68 & 32 & 0 & & 19 \\
\hline $2 \mathrm{H}-7,25-27$ & 12.05 & 0.333 & 85 & 61 & 69 & 31 & 0 & -1.65 & 16 \\
\hline $2 \mathrm{H}-7,35-37$ & 12.15 & 0.335 & 83 & 56 & 59 & 41 & 0 & & 19 \\
\hline $2 \mathrm{H}-7,45-47$ & 12.25 & 0.337 & 81 & 50 & 62 & 38 & 0 & -1.61 & 15 \\
\hline $2 \mathrm{H}-7,55-57$ & 12.35 & 0.339 & 74 & 46 & 51 & 49 & 0 & & 17 \\
\hline $3 \mathrm{H}-1,5-7$ & 12.45 & 0.346 & 58 & 57 & 100 & 0 & 0 & -0.73 & 0 \\
\hline $3 \mathrm{H}-1,15-17$ & 12.55 & 0.352 & 60 & 60 & 100 & 0 & 0 & & 0 \\
\hline $3 \mathrm{H}-1,25-27$ & 12.65 & 0.359 & 65 & 61 & 100 & 0 & 0 & -0.96 & 0 \\
\hline $3 \mathrm{H}-1,35-37$ & 12.75 & 0.363 & 65 & 60 & 87 & 13 & 0 & & 5 \\
\hline $3 \mathrm{H}-1,45-47$ & 12.85 & 0.366 & 66 & 55 & 76 & 24 & 0 & -1.29 & 9 \\
\hline $3 \mathrm{H}-1,55-57$ & 12.95 & 0.368 & 72 & 53 & 69 & 31 & 0 & & 12 \\
\hline $3 \mathrm{H}-1,65-67$ & 13.05 & 0.370 & 75 & 61 & 62 & 38 & 0 & -1.56 & 18 \\
\hline $3 \mathrm{H}-1,75-77$ & 13.15 & 0.373 & 71 & 68 & 64 & 36 & 0 & & 17 \\
\hline $3 \mathrm{H}-1,85-87$ & 13.25 & 0.375 & 73 & 68 & 69 & 31 & 0 & -1.37 & 15 \\
\hline $3 \mathrm{H}-1,95-97$ & 13.35 & 0.377 & 79 & 72 & 71 & 29 & 0 & & 17 \\
\hline $3 \mathrm{H}-1,105-107$ & 13.45 & 0.380 & 78 & 64 & 69 & 31 & 0 & -1.52 & 15 \\
\hline $3 \mathrm{H}-1,115-117$ & 13.55 & 0.382 & 77 & 60 & 69 & 31 & 0 & & 14 \\
\hline $3 \mathrm{H}-1,125-127$ & 13.65 & 0.384 & 76 & 57 & 69 & 31 & 0 & -1.71 & 14 \\
\hline $3 \mathrm{H}-1,135-137$ & 13.75 & 0.387 & 74 & 62 & 70 & 30 & 0 & & 14 \\
\hline $3 \mathrm{H}-1,145-147$ & 13.85 & 0.389 & 76 & 64 & 68 & 32 & 0 & -1.51 & 16 \\
\hline $3 \mathrm{H}-2,5-7$ & 13.95 & 0.391 & 72 & 61 & 77 & 23 & 0 & -1.63 & 10 \\
\hline $3 \mathrm{H}-2,15-17$ & 14.05 & 0.394 & 77 & 70 & 70 & 30 & 0 & & 16 \\
\hline $3 \mathrm{H}-2,25-27$ & 14.15 & 0.396 & 78 & 64 & 77 & 23 & 0 & -1.40 & 11 \\
\hline $3 \mathrm{H}-2,35-37$ & 14.25 & 0.398 & 79 & 72 & 79 & 21 & 0 & & 12 \\
\hline $3 \mathrm{H}-2,45-47$ & 14.35 & 0.401 & 78 & 69 & 86 & 14 & 0 & -1.86 & 7 \\
\hline $3 \mathrm{H}-2,55-57$ & 14.45 & 0.403 & 77 & 59 & 84 & 16 & 0 & & 7 \\
\hline $3 \mathrm{H}-2,65-67$ & 14.55 & 0.405 & 78 & 59 & 79 & 21 & 0 & -2.14 & 10 \\
\hline $3 \mathrm{H}-2,75-77$ & 14.65 & 0.408 & 75 & 53 & 79 & 21 & 0 & & 8 \\
\hline $3 \mathrm{H}-2,85-87$ & 14.75 & 0.410 & 73 & 52 & 71 & 29 & 0 & -2.30 & 11 \\
\hline $3 \mathrm{H}-2,95-97$ & 14.85 & 0.412 & 74 & 56 & 59 & 41 & 0 & & 17 \\
\hline $3 \mathrm{H}-2,105-107$ & 14.95 & 0.415 & 77 & 54 & 56 & 44 & 0 & -2.03 & 18 \\
\hline $3 \mathrm{H}-2,115-117$ & 15.05 & 0.417 & 78 & 54 & 52 & 48 & 0 & & 20 \\
\hline $3 \mathrm{H}-2,125-127$ & 15.15 & 0.419 & 74 & 58 & 55 & 45 & 0 & -1.54 & 19 \\
\hline $3 \mathrm{H}-2,135-137$ & 15.25 & 0.422 & 71 & 48 & 58 & 42 & 0 & & 14 \\
\hline
\end{tabular}


APPENDIX B (continued).

\begin{tabular}{|c|c|c|c|c|c|c|c|c|c|}
\hline \multirow[b]{2}{*}{$\begin{array}{l}\text { Core, section, } \\
\text { interval }(\mathrm{cm})\end{array}$} & \multirow[b]{2}{*}{$\begin{array}{l}\text { Depth } \\
\text { (m) }\end{array}$} & \multirow[b]{2}{*}{$\begin{array}{l}\text { Time } \\
\text { (Ma) }\end{array}$} & \multirow[b]{2}{*}{$\begin{array}{c}\text { Carbonate } \\
(\%)\end{array}$} & \multirow[b]{2}{*}{$\begin{array}{c}\text { Fine } \\
\text { fraction } \\
(\%)\end{array}$} & \multicolumn{3}{|c|}{ Carbonate mineralogy } & \multirow[b]{2}{*}{$\begin{array}{c}\delta^{18} \mathrm{O} \text { PDB } \\
\text { G. sacculifera } \\
(\% 0)\end{array}$} & \multirow[b]{2}{*}{$\begin{array}{c}\text { Aragonite } \\
\text { to total } \\
\text { sediment }(\%)\end{array}$} \\
\hline & & & & & $\begin{array}{c}\text { Aragonite } \\
(\%)\end{array}$ & $\begin{array}{c}\text { Calcite } \\
(\%)\end{array}$ & $\begin{array}{c}\mathrm{Mg} \\
\text { calcite } \\
(\%)\end{array}$ & & \\
\hline $3 \mathrm{H}-2,145-147$ & 15.35 & 0.425 & 68 & 42 & 71 & 29 & 0 & -1.41 & 8 \\
\hline $3 \mathrm{H}-3,5-7$ & 15.45 & 0.430 & 68 & 47 & 80 & 20 & 0 & -1.01 & 6 \\
\hline $3 \mathrm{H}-3,15-17$ & 15.55 & 0.434 & 59 & 53 & 76 & 24 & 0 & & 8 \\
\hline $3 \mathrm{H}-3,25-27$ & 15.65 & 0.439 & 59 & 55 & 79 & 21 & 0 & -0.75 & 7 \\
\hline $3 \mathrm{H}-3,35-37$ & 15.75 & 0.444 & 58 & 54 & 100 & 0 & 0 & & 0 \\
\hline $3 \mathrm{H}-3,45-47$ & 15.85 & 0.448 & 62 & 56 & 100 & 0 & 0 & & 0 \\
\hline $3 \mathrm{H}-3,55-57$ & 15.95 & 0.453 & 58 & 56 & 100 & 0 & 0 & & 0 \\
\hline $3 \mathrm{H}-3,65-67$ & 16.05 & 0.457 & 61 & 38 & 100 & 0 & 0 & -0.86 & 0 \\
\hline $3 \mathrm{H}-3,75-77$ & 16.15 & 0.462 & 62 & 47 & 100 & 0 & 0 & & 0 \\
\hline $3 \mathrm{H}-3,85-87$ & 16.25 & 0.467 & 63 & & 100 & 0 & 0 & -0.80 & \\
\hline $3 \mathrm{H}-3,95-97$ & 16.35 & 0.471 & 62 & 54 & 100 & 0 & 0 & & 0 \\
\hline $3 \mathrm{H}-3,105-107$ & 16.45 & 0.476 & 58 & 57 & 100 & 0 & 0 & -0.86 & 0 \\
\hline $3 \mathrm{H}-3,115-117$ & 16.55 & 0.479 & 57 & 58 & 100 & 0 & 0 & & 0 \\
\hline $3 \mathrm{H}-3,125-127$ & 16.65 & 0.481 & 62 & 54 & 100 & 0 & 0 & -0.83 & 0 \\
\hline $3 \mathrm{H}-3,135-137$ & 16.75 & 0.483 & 62 & 62 & 100 & 0 & 0 & & 0 \\
\hline $3 \mathrm{H}-3,145-147$ & 16.85 & 0.484 & 59 & 50 & 100 & 0 & 0 & -0.79 & 0 \\
\hline $3 \mathrm{H}-4,5-7$ & 16.95 & 0.486 & 63 & 50 & 100 & 0 & 0 & -1.12 & 0 \\
\hline $3 \mathrm{H}-4,15-17$ & 17.05 & 0.488 & 62 & 62 & 100 & 0 & 0 & & 0 \\
\hline $3 \mathrm{H}-4,25-27$ & 17.15 & 0.490 & 60 & 62 & 90 & 10 & 0 & -1.00 & 4 \\
\hline $3 \mathrm{H}-4,35-37$ & 17.25 & 0.492 & 72 & 66 & 80 & 20 & 0 & & 9 \\
\hline $3 \mathrm{H}-4,45-47$ & 17.35 & 0.494 & 71 & 65 & 77 & 23 & 0 & & 11 \\
\hline $3 \mathrm{H}-4,55-57$ & 17.45 & 0.495 & 76 & 67 & 81 & 19 & 0 & & 10 \\
\hline $3 \mathrm{H}-4,65-67$ & 17.55 & 0.497 & 80 & 66 & 76 & 24 & 0 & -1.44 & 13 \\
\hline $3 \mathrm{H}-4,75-77$ & 17.65 & 0.499 & 76 & 53 & 70 & 30 & 0 & & 12 \\
\hline $3 \mathrm{H}-4,85-87$ & 17.75 & 0.501 & 79 & 54 & 70 & 30 & 0 & -1.73 & 13 \\
\hline $3 \mathrm{H}-4,95-97$ & 17.85 & 0.503 & 79 & 53 & 67 & 33 & 0 & & 14 \\
\hline $3 \mathrm{H}-4,102-104$ & 17.92 & 0.504 & 79 & 55 & 66 & 34 & 0 & -1.84 & 15 \\
\hline $3 \mathrm{H}-5,5-7$ & 18.45 & 0.514 & 78 & 60 & 78 & 22 & 0 & -1.39 & 10 \\
\hline $3 \mathrm{H}-5,15-17$ & 18.55 & 0.516 & 77 & 62 & 83 & 17 & 0 & & 8 \\
\hline $3 \mathrm{H}-5,25-27$ & 18.65 & 0.518 & 78 & 55 & 77 & 23 & 0 & -1.45 & 10 \\
\hline $3 \mathrm{H}-5,35-37$ & 18.75 & 0.519 & 79 & 59 & 71 & 29 & 0 & & 14 \\
\hline $3 \mathrm{H}-5,45-47$ & 18.85 & 0.521 & 76 & 57 & 76 & 24 & 0 & & 10 \\
\hline $3 \mathrm{H}-5,55-57$ & 18.95 & 0.523 & 73 & 44 & 78 & 22 & 0 & & 7 \\
\hline $3 \mathrm{H}-5,65-67$ & 19.05 & 0.525 & 75 & 20 & & & 0 & -1.46 & \\
\hline $3 \mathrm{H}-5,75-77$ & 19.15 & 0.527 & 70 & 47 & 87 & 13 & 0 & & 4 \\
\hline $3 \mathrm{H}-5,85-87$ & 19.25 & 0.529 & 69 & 46 & 100 & 0 & 0 & -1.48 & 0 \\
\hline $3 \mathrm{H}-5,95-97$ & 19.35 & 0.530 & 70 & 44 & 94 & 6 & 0 & & 2 \\
\hline $3 \mathrm{H}-5,108-110$ & 19.48 & 0.533 & 74 & 49 & 86 & 14 & 0 & -1.36 & 5 \\
\hline
\end{tabular}

